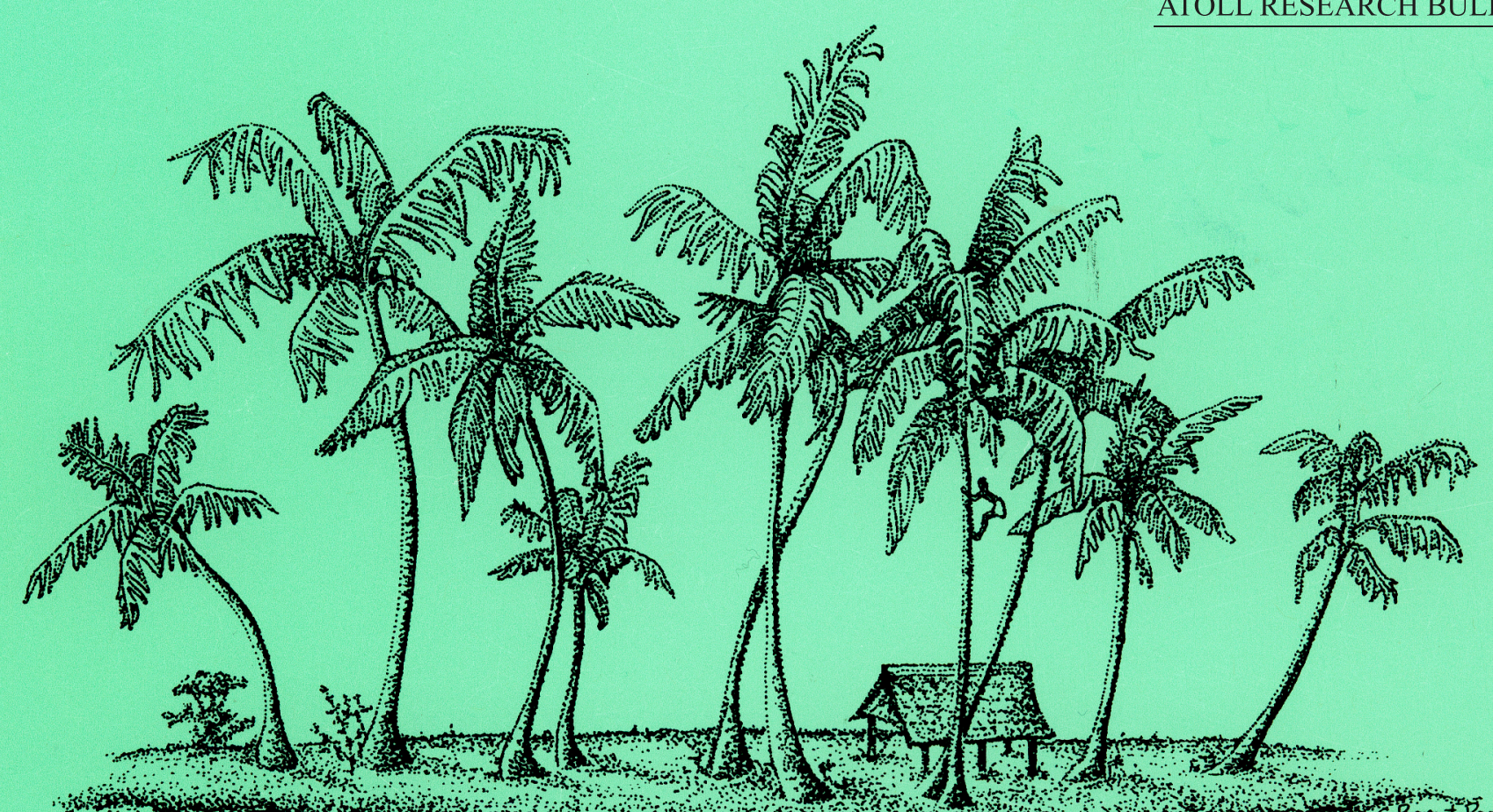

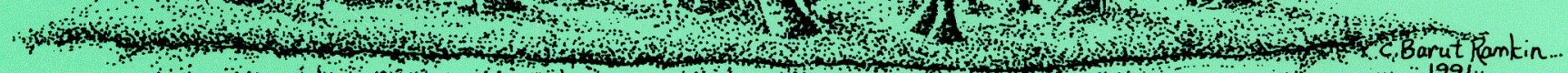

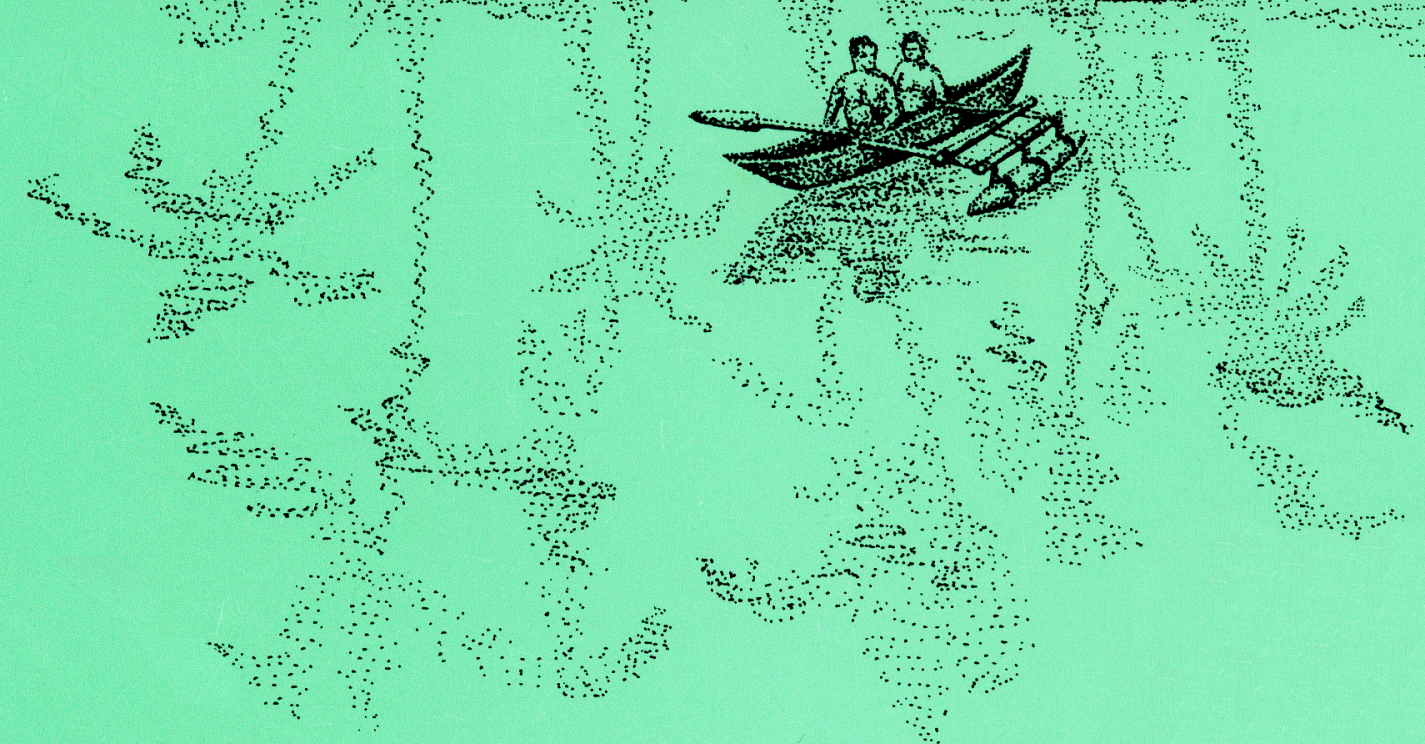

ANOMURA (CRUSTACEA DECAPODA) FROM THE MAYOTTE REGION, WESTERN INDIAN OCEAN

Joseph Poupin, Jean-Marie Bouchard, Vincent Dinhut, Régis Cleva, and Jacques Dumas

Smithsonian Institution Scholarly Press

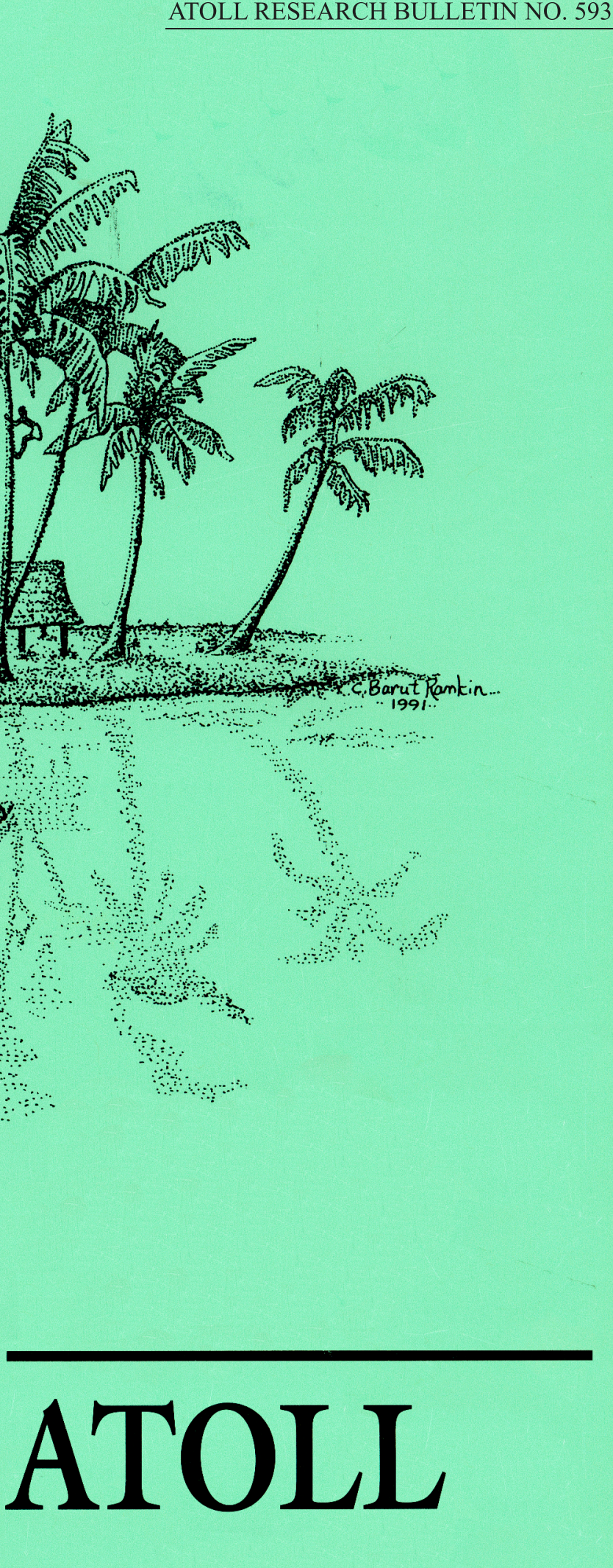

\section{ATOLL}

RESEARCH

BULLETIN 


\section{ANOMURA (CRUSTACEA DECAPODA) FROM THE MAYOTTE REGION, WESTERN INDIAN OCEAN}

Joseph Poupin, Jean-Marie Bouchard, Vincent Dinhut, Régis Cleva and Jacques Dumas

Atoll Research Bulletin No. 593 • 23 October 2013

Smithsonian Institution Scholarly Press 
All statements made in papers published in the Atoll Research Bulletin are the sole responsibility of the authors and do not necessarily represent the views of the Smithsonian Institution or of the editors of the Bulletin. Articles submitted for publication in the Atoll Research Bulletin should be original papers and must be made available by authors for open access publication. Manuscripts should be consistent with the "Author Formatting Guidelines for Publication in the Atoll Research Bulletin." All submissions to the Bulletin are peer reviewed and, after revision, are evaluated prior to acceptance and publication through the publisher's open access portal, Open SI (http://opensi.si.edu).

Published by SMITHSONIAN INSTITUTION SCHOLARLY PRESS

P.O. Box 37012, MRC 957

Washington, D.C. 20013-7012

www.scholarlypress.si.edu

The rights to all text and images in this publication are owned either by the contributing authors or third parties. Fair use of materials is permitted for personal, educational, or noncommercial purposes. Users must cite author and source of content, must not alter or modify the content, and must comply with all other terms or restrictions that may be applicable. Users are responsible for securing permission from a rights holder for any other use.

ISSN: 0077-5630 (online) 


\section{CONTENT}

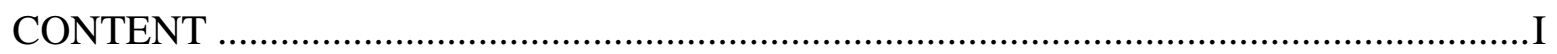

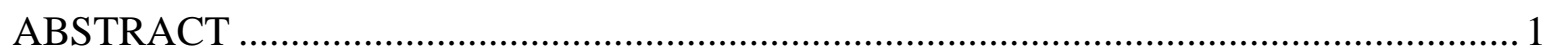

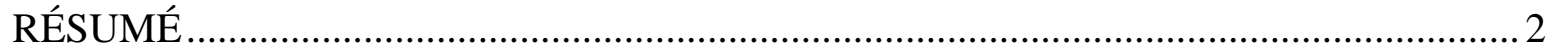

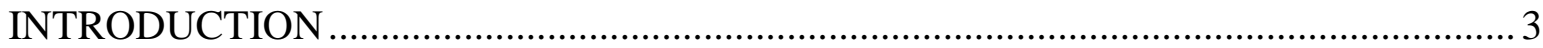

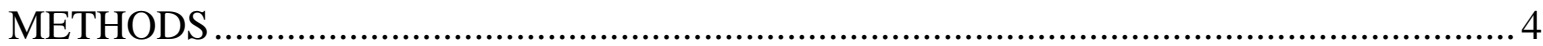

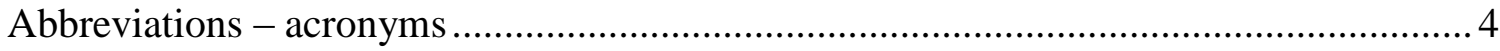

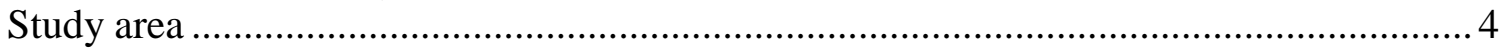

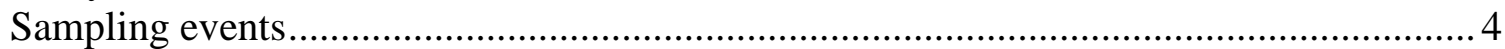

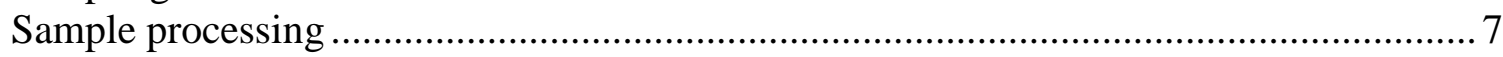

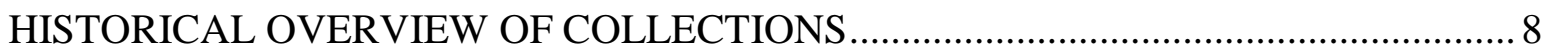

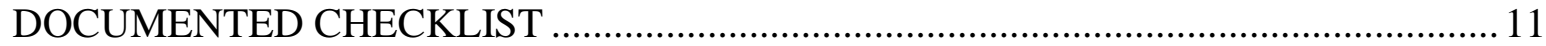

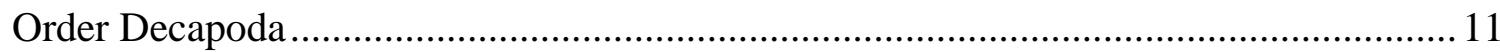

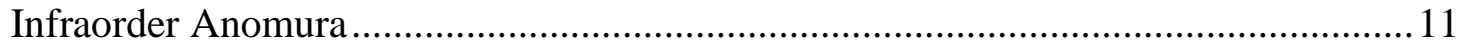

Superfamily Chirostyloidea............................................................................... 11

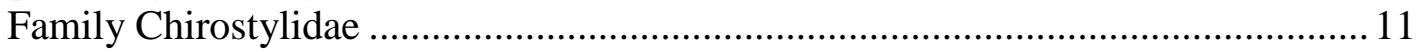

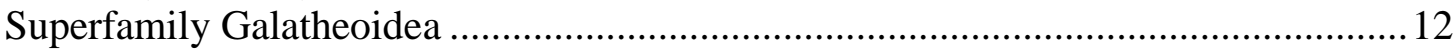

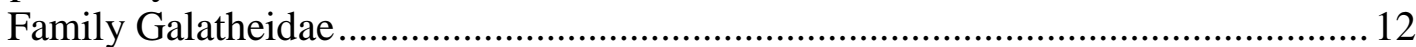

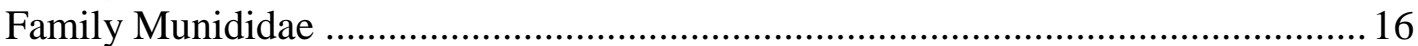

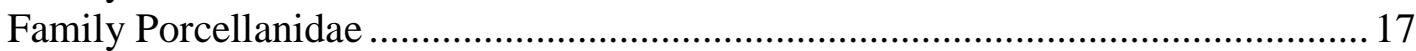

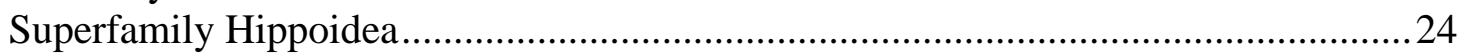

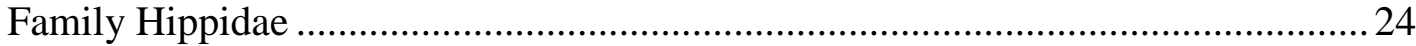

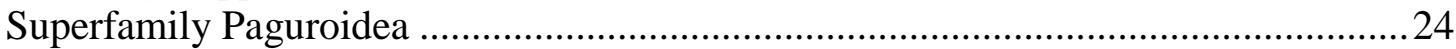

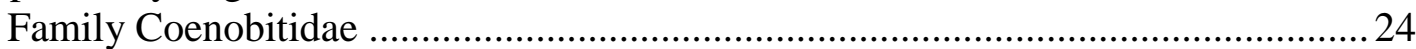

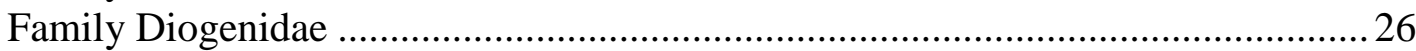

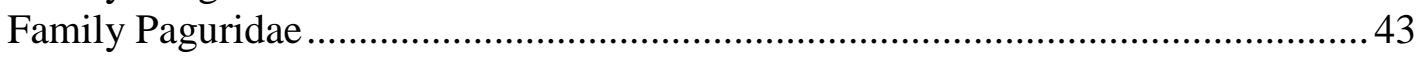

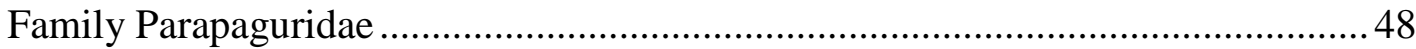

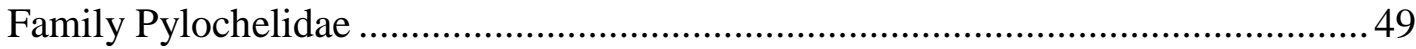

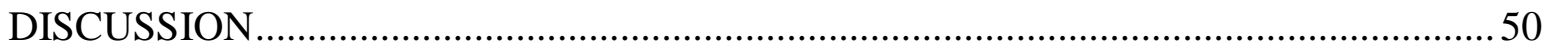

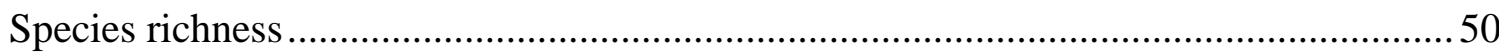

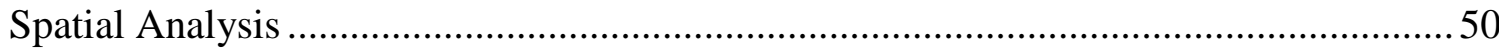

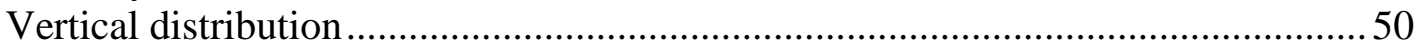

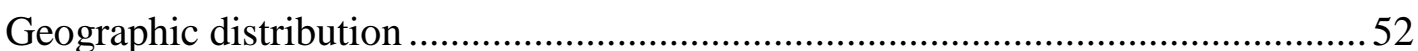

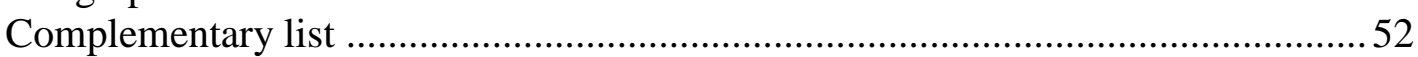

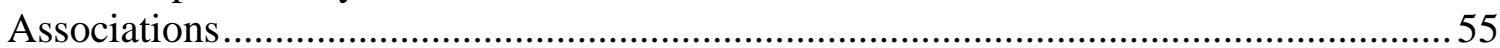




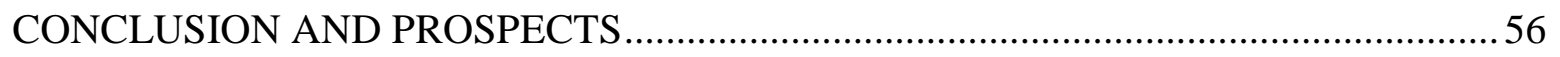

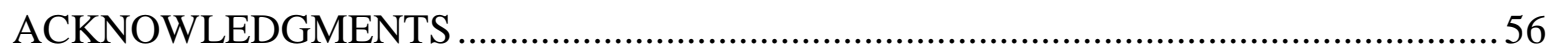

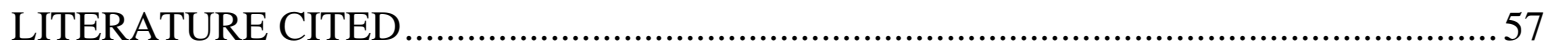

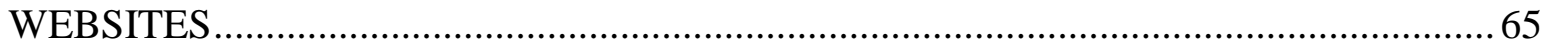

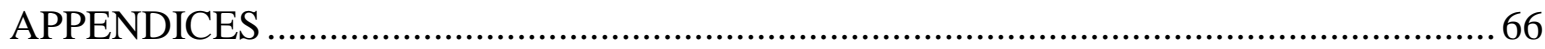

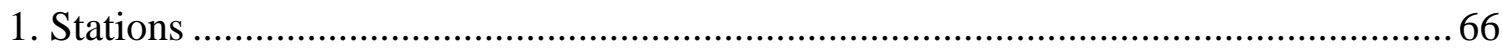

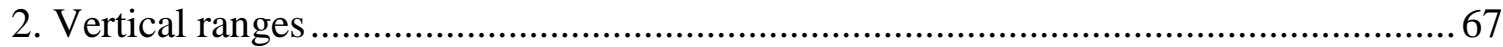

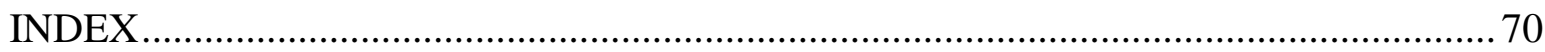


This study is dedicated to Dr. Patsy A. McLaughlin (1932-2011)

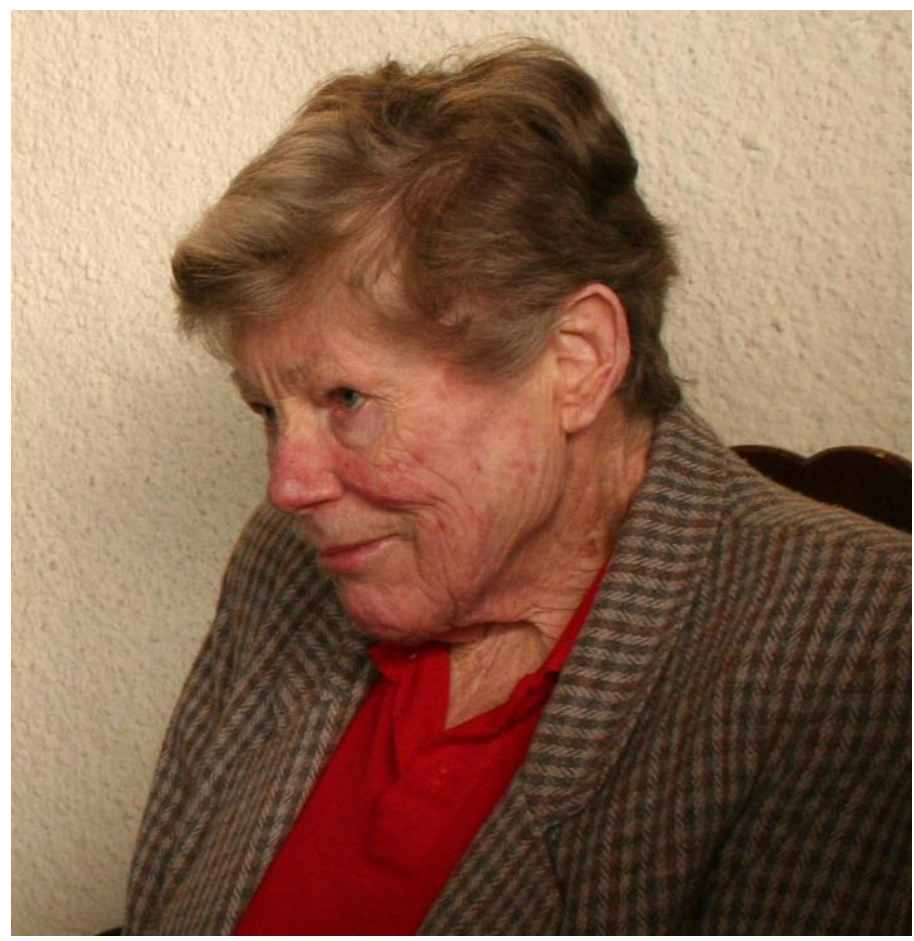

Pat passed away on April 4, 2011 while this study was in progress. She was an esteemed colleague and the most influential expert on the Anomura. Her help in this study was much appreciated. 


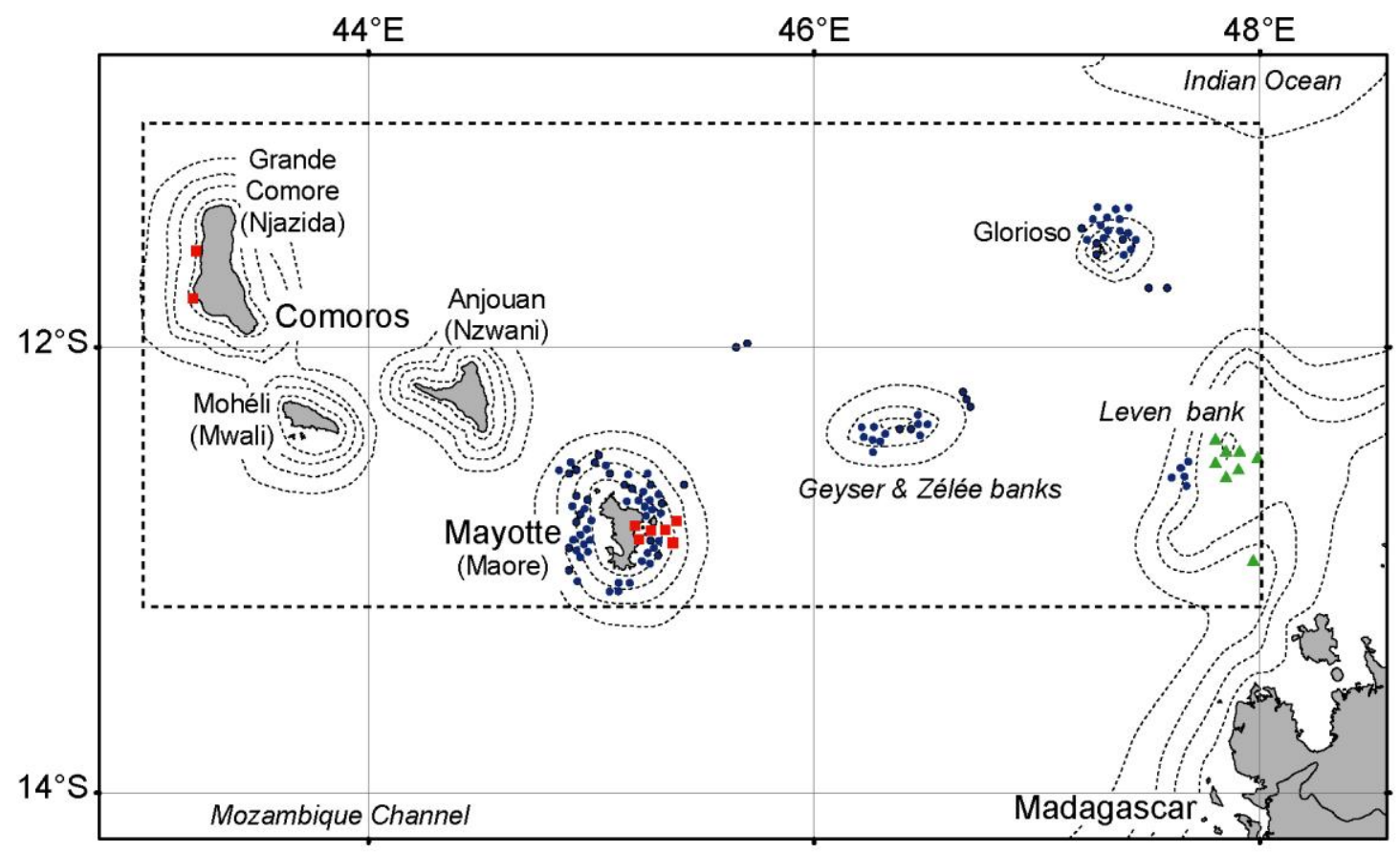

Figure 1. 'Mayotte region' as defined for this study (dotted rectangle). This includes Comoros (Grande Comore, Mohéli, Anjouan), Mayotte (Maoré), and Glorioso Islands plus three marine banks (Zélée, Geyser, Leven). Places of collections for three expeditions that have sampled the Crustacea of this region are indicated: red squares, R/V Anton Bruun ninth cruise (1964); blue circles, R/V Surô̂t BENTHEDI cruise (1977); green triangles, shrimp boat Miriky MIRIKY cruise (2009) (see Historical overview of collections). 


\title{
ANOMURA (CRUSTACEA DECAPODA) FROM THE MAYOTTE REGION, WESTERN INDIAN OCEAN
}

BY

\section{JOSEPH POUPIN ${ }^{1}$, JEAN-MARIE BOUCHARD ${ }^{2}$, VINCENT DINHUT ${ }^{2,}$ REGIS CLEVA ${ }^{3}$, AND JACQUES DUMAS ${ }^{4}$,}

\begin{abstract}
A documented and illustrated checklist of the Anomura is presented for the Mayotte region, Western Indian Ocean. The study area is situated between longitudes $43-48^{\circ} \mathrm{E}$ and latitudes $11-13^{\circ} 10^{\prime} \mathrm{S}$. It includes Comoros, Mayotte, and Glorioso Islands plus three marine banks (Zélée, Geyser, Leven). Records included are from fieldwork in Mayotte during November 2009, and complemented by a review of the literature. In total 75 species are listed including 43 new records for the Mayotte region. The inventory includes 51 Paguroidea, 22 Galatheoidea, 1 Chirostyloidea (Eumunida sp.) and 1 Hippoidea (Hippa adactyla). The Diogenidae are best represented with 29 species of Aniculus, Areopaguristes, Calcinus, Ciliopagurus, Clibanarius, Dardanus, Diogenes, Paguristes and Pseudopaguristes. Other families represented are the Porcellanidae, with 13 species of the Aliaporcellana, Neopetrolisthes, Pachycheles, Petrolisthes, Pisidia, Polyonyx; the Paguridae, with 11 species of Anapagrides, Catapagurus, Cestopagurus, Pagurixus, Pagurus, Pylopaguropsis, Trichopagurus; and the Galatheidae, with 7 species of Galathea and Macrothea. Only a few species are listed for the families Coenobitidae, with 5 species of Birgus and Coenobita; Parapaguridae, with 3 species of Paragiopagurus, Strobopagurus, Sympagurus; Pylochelidae, with 3 species of Cheiroplatea, Pomatocheles, Trizocheles; Munididae, with 2 species of Munida and Sadayoshia; and Chirostylidae, with 1 species of Eumunida. Biotopes investigated include the intertidal area (on foot at low tide) and shallow-waters of the lagoon (scuba diving between 0-62 m). Based on previous marine campaigns in Mayotte region, 11 species are also reported in the 200-700 $\mathrm{m}$ depth range.

\footnotetext{
${ }^{1}$ Institut de Recherche de l'Ecole Navale, IRENav, BP 600, 29240 BREST, France (joseph.poupin@ecolenavale.fr) - Corresponding author.

${ }^{2}$ KUW Cie - Kraken Underwater Works, 40, rue Babou Salama, 97600 MAMOUDZOU, Mayotte (jeanmarie.bouchard@orange.fr)

${ }^{3}$ Muséum national d'Histoire naturelle, Direction des Collections, Crustacés, Case Postale 53, rue Buffon 61, 75005 Paris, France [retired in 2010].

${ }^{4}$ Commission Nationale Environnement et Biologie Subaquatiques, Fédération Française d'Etude et de Sport Sousmarin, FFESSM.
} 
The anomuran fauna of Mayotte region is predominantly Indo-West Pacific in its composition (85\% of the species). Twelve species are distributed in Western Indian Ocean only. A comparison with the anomuran fauna of adjacent regions shows that at least 129 anomuran species are potentially present in Mayotte region. Groups that need better sampling include Hippoidea, Diogenidae, and Porcellanidae.

\section{RÉSUMÉ}

Une liste documentée et illustrée des anomoures de la région de Mayotte est proposée. La zone étudiée est comprise entre les longitudes $43-48^{\circ} \mathrm{E}$ et les latitudes $11-13^{\circ} 10^{\prime} \mathrm{S}$. Elle comprend les îles Comores, Mayotte, et Glorieuses et trois bancs marins (Zélée, Geyser, Leven). Les signalements proviennent d'un atelier de terrain, réalisé à Mayotte en novembre 2009, complétés par une recherche bibliographique. Au total, 75 espèces sont identifiées dont 43 nouveaux signalements pour la région. Cet inventaire comprend 51 Paguroidea, 22 Galatheoidea, 1 Chirostyloidea (Eumunida sp.) et 1 Hippoidea (Hippa adactyla). Les Diogenidae prédominent avec 29 espèces des genres Aniculus, Areopaguristes, Calcinus, Ciliopagurus, Clibanarius, Dardanus, Diogenes, Paguristes et Pseudopaguristes. Les autres familles sont les Porcellanidae (13 espèces des genres Aliaporcellana, Neopetrolisthes, Pachycheles, Petrolisthes, Pisidia, Polyonyx), Paguridae (11 espèces des genres Anapagrides, Catapagurus, Cestopagurus, Pagurixus, Pagurus, Pylopaguropsis, Trichopagurus), et Galatheidae (7 espèces des genres Galathea et Macrothea). Les familles qui ne sont représentées que par quelques espèces sont les Coenobitidae (5 espèces, genres Birgus, Coenobita), Parapaguridae (3 espèces, genres Paragiopagurus, Strobopagurus, Sympagurus), Pylochelidae (3 espèces, genres Cheiroplatea, Pomatocheles, Trizocheles), Munididae (2 espèces, genres Munida, Sadayoshia), et Chirostylidae (1 espèce, genre Eumunida). Les biotopes visités comprennent la zone intertidale, explorée à pied à marée basse, et les petits fonds du lagon avec des plongées entre 0-62 m. Les grands fonds marins ont été explorés au cours de campagnes maritimes anciennes, avec 11 espèces signalées entre 200-700 m. Les anomoures de la région de Mayotte sont d'origine Indo-ouest Pacifique (85\%). Douze espèces ne sont connues que de l'océan Indien occidental. Une comparaison avec la faune des régions voisines montre qu'au moins 129 anomoures sont potentiellement présents dans la région de Mayotte. Les groupes qui doivent être mieux échantillonnés à l'avenir sont les Hippoidea, Diogenidae et Porcellanidae. 


\section{INTRODUCTION}

This study is the second of a series that aims to present the faunistic results obtained during the Kraken Underwater Works $\mathrm{C}^{\text {ie }}$ (KUW) fieldwork, held in Mayotte Island, southwestern Indian Ocean, in November 1-21, 2009. This fieldwork was organized by J.-M. Bouchard, head of the KUW Cie at Mayotte, with scientific participation of the Institut de Recherche de l'Ecole Navale (IRENav), Brest, and the Muséum national d'Histoire naturelle (MNHN), Paris. It was supported by the DAF (Direction de l'Agriculture et de la Forêt) of Mayotte and Total foundation, and was dedicated to the inventory of the Crustacea Decapoda and Stomatopoda of the island.

The first study by Bouchard et al. (2011) was devoted to the land, mangrove, and freshwater species and includes a presentation of the KUW 2009 fieldwork with a map and detailed list of the 39 stations realized.

The present study is dedicated to the Anomura. The Galatheidae and Munididae have been already partly published in a systematic review by Macpherson \& Cleva (2010) with description of one new genera (Macrothea) and two new species (Galathea denticulata, Macrothea bouchardi). Additional families treated here are the Eumunididae, Porcellanidae, Hippidae, Coenobitidae, Diogenidae, Paguridae, Parapaguridae, Pylochelidae. Three taxa have been recognized has new species and are treated separately in systematic revisions. These are a porcellanid, Polyonyx aff. boucheti, and two pagurids (Cestopagurus caeruleus Komai \& Poupin, 2012, and Trichopagurus asper Komai \& Poupin, 2012).

In complement of the species collected during the KUW fieldwork a literature search of anomuran species previously recorded in Mayotte region (as defined in figure 1) has been realized and the main steps for collections of the anomuran in this region are presented in an historical overview.

For each species the list includes: a documented origin of the record(s), geographic distribution (with depth range), and additional remarks, when needed. To facilitate the identification most of the species are illustrated by photographs, most of them taken during the KUW fieldwork. Species richness is discussed after the checklist as are the ecology and biogeography of the anomurans of Mayotte region. An additional list of 50 common anomurans that could be reasonably found in the region in the future is also included. 


\section{METHODS}

\section{ABBREVIATIONS - ACRONYMS}

ANR, French Agence Nationale de la Recherche; BIOTAS, acronym for a research program at la Réunion: 'The Southwest Indian Ocean biodiversity hotspot: A biota-level study of diversification on land and sea'; ECOMAR, Laboratoire d'Ecologie marine, Université de la Réunion; IFREMER, Institut français de recherche pour l'exploitation de la mer; IO, Indian Ocean; IRD, Institut de Recherche pour le Développement, IWP, Indo-West Pacific; KUW, Kraken Underwater Works $C^{\text {ie }}$, Mamoudzou, Mayotte; Lc, carapace length; Lt, total length; MEPA, acronym for 'Mission îles Eparses' part of the BIOTAS program; MNHN, Muséum national d'Histoire naturelle, Paris; ORSTOM, Institut Français de Recherche Scientifique pour le Développement en Coopération (changed in IRD since 1998); P1, pereiopod 1 or cheliped, P2-4, pereiopods 2-4 or first to third walking legs; P5, pereiopod 5 or last legs; PNI, Pro-Natura International; R/V, Research Vessel; S1, shield length; St., Station; UF, Florida Museum of Natural History, Gainesville; USNM, National Museum of Natural History, Smithsonian Institution, Washington, D.C.; WIO, Western Indian Ocean.

\section{STUDY AREA}

The study area 'Mayotte region' is defined in figure 1. It includes Mayotte Island, the Comoros archipelago (Grande Comore or Njazida, Mohéli or Mwali, Anjouan or Nzwani) and the Glorioso Islands. These islands are located within a rectangle delimited by longitudes 43$48^{\circ} \mathrm{E}$ and latitudes $11-13^{\circ} 10^{\prime} \mathrm{S}$. Three marine banks are also included: Zélée, Geyser, and Leven banks. The Zélée and Leven banks are submerged, with their summits at 10-17 $\mathrm{m}$ and 15$70 \mathrm{~m}$, respectively; the Geyser bank is partly exposed at low tide (see Daniel et al., 1972; Thomassin et al., 2009).

\section{SAMPLING EVENTS}

Details on the 39 stations sampled in the Mayotte region are available in Bouchard et al. (2011), and online [1]. In addition, a few stations made in the Glorioso Islands by BIOTAS team (M. Malay and colleagues) in May 2009, are also listed in Appendix 1 (see also Historical overview of Collections). 


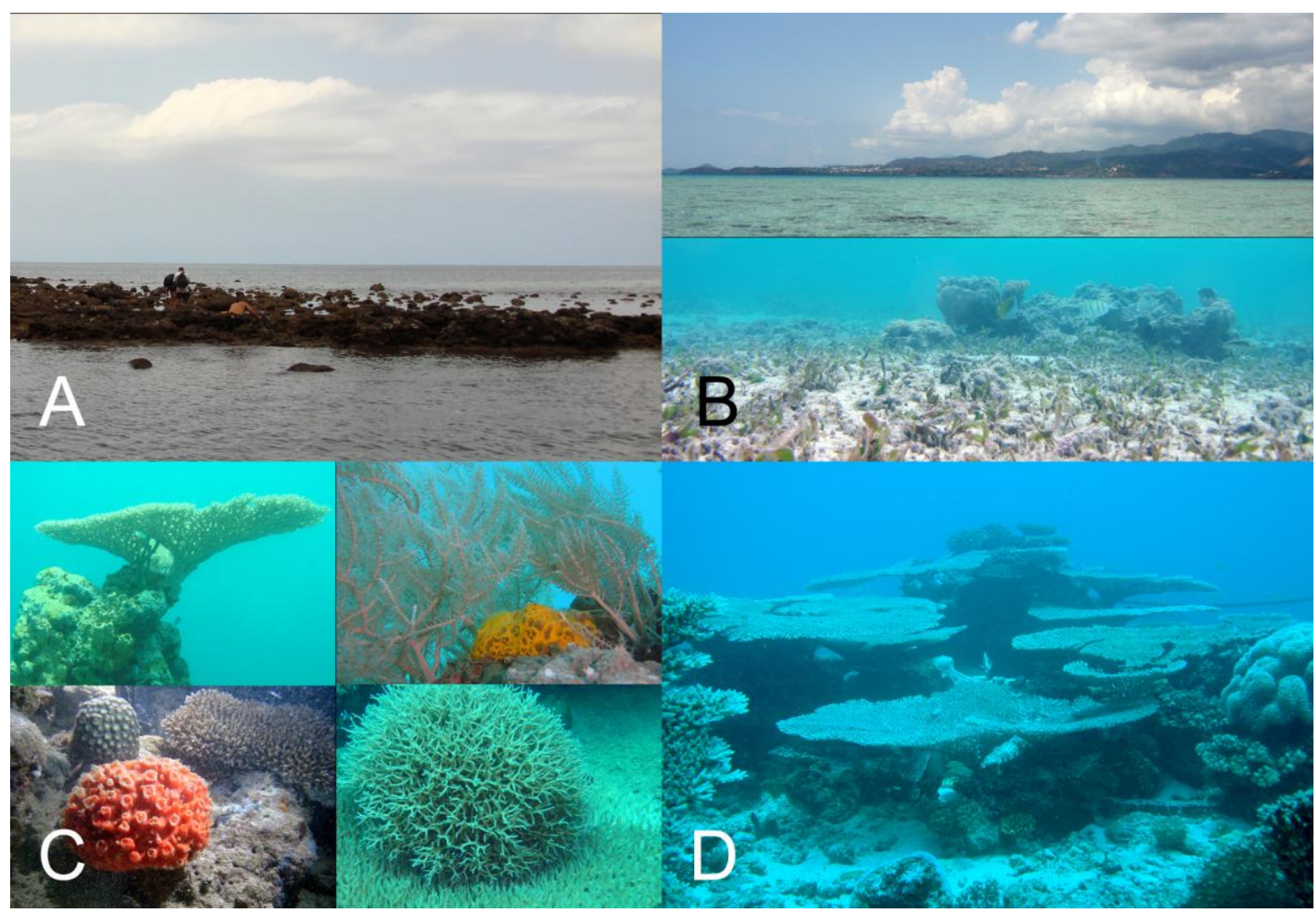

Figure 2. Aspect of some biotopes studied during the KUW 2009 fieldwork with list of anomurans species collected.

A) Intertidal area at low tide, St. 10, islet Quatre Frères (Vatou), rocks and tide pools: Clibanarius eurysternus, Clibanarius humilis, Clibanarius laevimanus, Clibanarius rhabdodactylus, Petrolisthes lamarckii.

B) Shallow waters of the lagoon, St. 5, Great north east reef, seagrass bed and sand, $1 \mathrm{~m}$ : Calcinus latens, Ciliopagurus tricolor, Dardanus lagopodes, Dardanus scutellatus, Neopetrolisthes maculatus, Pagurus hirtimanus.

C) Four aspects of St. 12 (visited during day and night) soft and stony corals (Acropora, Pocillopora, Seriatopora ...), sponges, coral boulders, sand bottom, 6-12 m: Calcinus rosaceus, Calcinus latens, Cestopagurus caeruleus, Dardanus deformis, Dardanus guttatus, Galathea aegyptiaca, Galathea mauritiana, Pagurixus rubrovittatus, Polyonyx aff. boucheti.

D) St. 14, La Prudente bank, various corals (Acropora, Pocillopora ...), coral boulders, sponges, sand bottom, 15-17 m: Aliaporcellana pygmaea, Areopaguristes abbreviatus, Calcinus rosaceus, Cestopagurus caeruleus, Galathea denticulata, Galathea tanegashimae, Galathea mauritiana, Pagurixus carinimanus, Polyonyx triunguiculatus. 
Anomura were collected at low tide in the intertidal area (Fig. 2 A) or during scuba dives in the lagoon and outer reef (Fig. 2 B-D, 4). The dives were made between 1-35 m with a single dive at $62 \mathrm{~m}$. Largest species were collected by hand or photographed in situ when they could be clearly identified based on color pattern, such as Dardanus spp. or Ciliopagurus tricolor (Fig. 3). Medium to small-sized species were usually collected mixed with coral debris and rubble brought to the surface in large bins for carefull sorting after each dive (Fig. 4 C-D). The smallest species (e.g. Polyonyx spp., Pagurixus spp.) were collected in fine coral sediment collected with a suction pump associated with a $1 \mathrm{~mm}$ mesh filter (Fig. 4 A-B). Details on these sampling techniques are in Bouchard et al. (2009: 9-12).

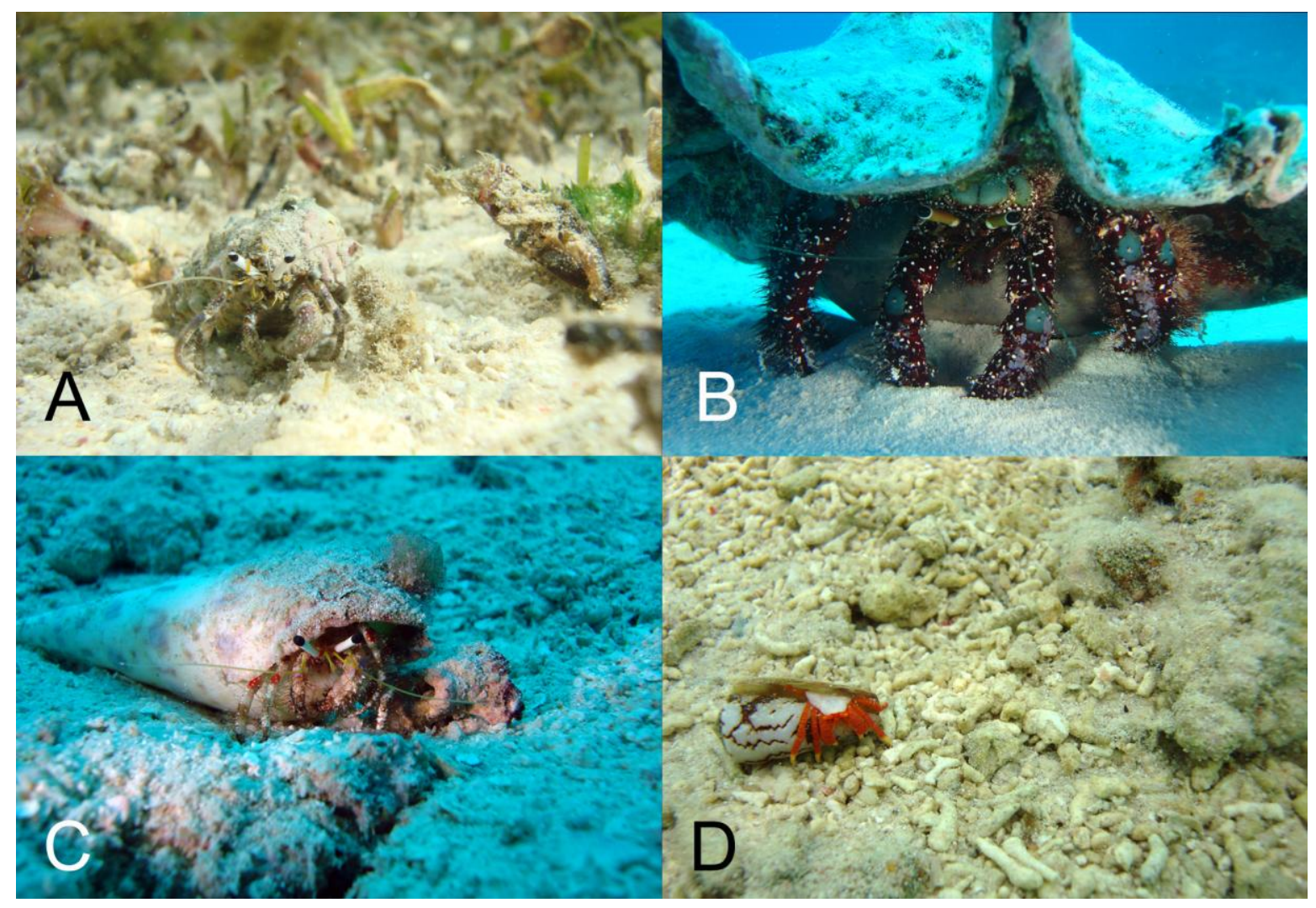

Figure 3. Examples of a few anomurans from Mayotte recognized in situ based on their color pattern. A) Dardanus scutellatus, St. 5, Great north-eastern reef, seagrass bed, $1 \mathrm{~m}$. B) Dardanus guttatus, St. 17, North reef, sand bottom, 22 m. C) Dardanus lagopodes, St. 20b, islet M'tzamboro, sand and coral rubbles, 10-15 m. D) Ciliopagurus tricolor, St. 5, Great north east reef, coral rubbles, $1 \mathrm{~m}$. 


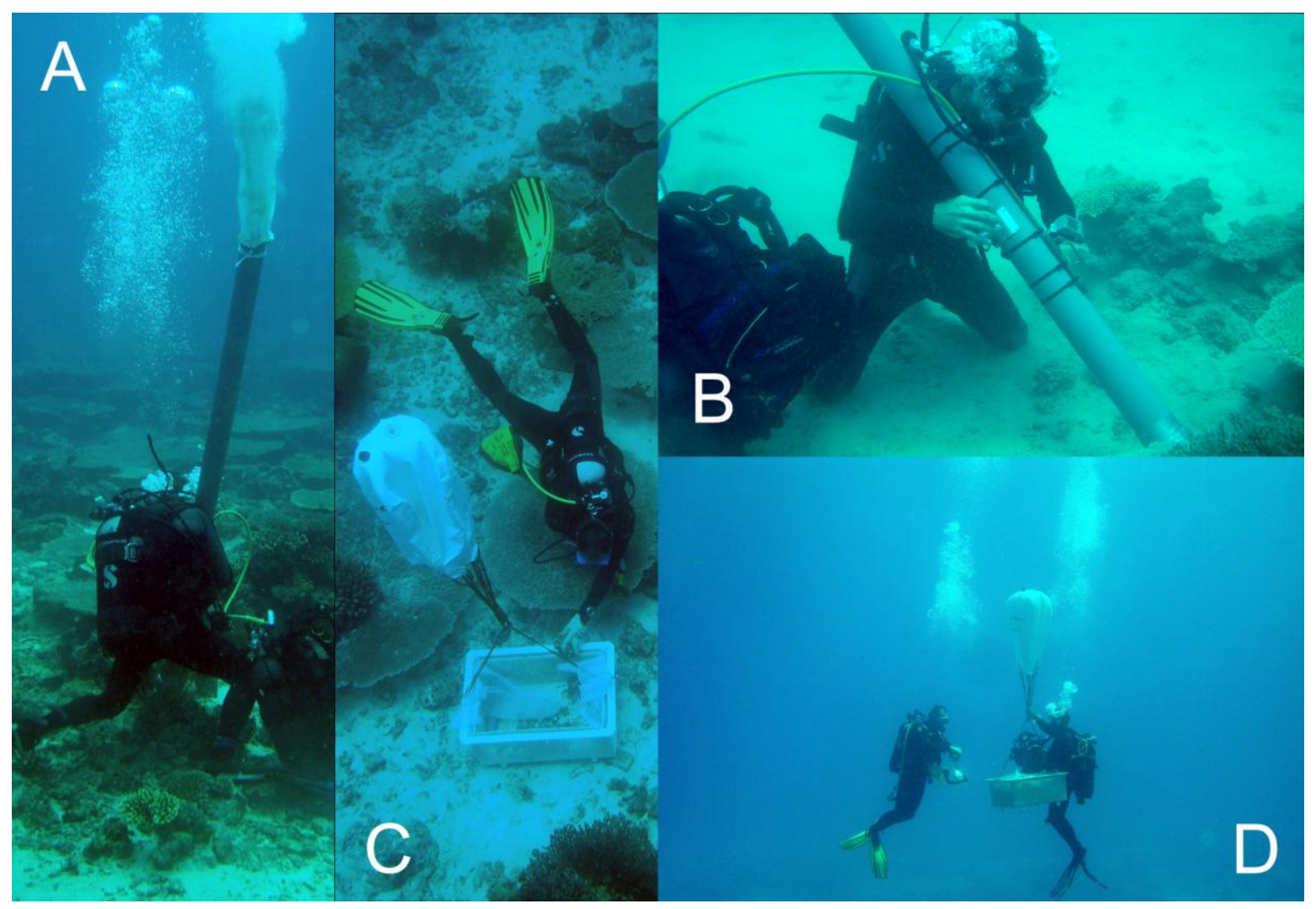

Figure 4. Sampling techniques used during KUW 2009 fieldwork. A-B) suction pump with a 1 $\mathrm{mm}$ mesh filter, at St. 12. C-D) collection of corals, coral rubbles, and brushing of coral blocks under water in a bin brought back to the surface using a parachute (C at St. 12, D at St. 17).

\section{SAMPLE PROCESSING}

Species identifications were made at the Institut de Recherche de l'Ecole Navale (IRENav) and the Muséum national d'Histoire naturelle, Paris (MNHN). All specimens have been deposited and recorded in MNHN collections.

For the Galatheidae the size is expressed as postorbital carapace length (Lc). For crab-like Anomura of the Porcellanidae the size is the length $\times$ width of the carapace. For the Paguroidea $\mathrm{Sl}$ is the shield length, Lc is the length of the cephalothorax (S1 plus posterior soft carapace), and Lt is total length (usually for specimens photographed, including length of extended chelipeds).

All photographs made are available in the online resource developed at IRENav to facilitate the study of this collection after the KUW fieldwork [1]. This database is regularly updated and also includes stations data, map, field observations, previous records of anomurans in the Mayotte region, an relevant references. 


\section{HISTORICAL OVERVIEW OF COLLECTIONS}

To complement the historical overview made for the land crustaceans (Bouchard et al., 2011), the main episodes for the collections of marine crustaceans in Mayotte region are herein presented, with focus on the anomurans.

Unsurprisingly the first anomuran mentioned from Mayotte region is the common Coenobita rugosus, reported by Hoffmann (1874: 29) as 'C. clypeatus'. The specimens studied by Hoffmann were collected by F.P.L. Pollen and D.C. Van Dam, and are deposited in the Nationaal Natuurhistorisch Museum (ex Rijksmuseum van Natuurlijke Historie), Leiden. A narration of this expedition is given by Pollen (1868) with a sojourn in Mayotte Island in AprilMay 1864.

In 1882 the British HMS Alert stopped in the Glorioso Islands and the surgeon of the expedition, R. W. Coppinger (1884) mentions the presence in these Islands of the coconut crab, Birgus latro, a record thereafter confirmed by Miers (1884) in his study of the Crustacea of the expedition and deposited in the Natural History Museum, London. For this study, the coconut crab is again reported from Glorioso Islands (see Bouchard et al., 2011: 11).

In his 'Notes sur la faune intercotidale des Comores' Pierre Fourmanoir (1955), an ichthyologist at the French ORSTOM Institute, Nosy Be, Madagascar, reported nine common anomurans from Grande Comore, Mohéli, Anjouan and Mayotte: Aniculus aniculus, Calcinus spp., Dardanus deformis, Galathea mauritiana, Pagurus hirtimanus, Petrolisthes spp. and, interestingly, the single mole crab reported up to now from Mayotte region, Hippa adactyla.

Between 1958 and 1971, collections of anomurans were obtained in Mayotte and Glorioso Islands by Alain Crosnier, a carcinologist and colleague of Pierre Fourmanoir at Nosy Be ORSTOM Institute. Most of Crosnier' specimens were collected in 1959 in Mayotte, during the geomorphologic campaign of the R/V ORSTOM II (see Guilcher et al., 1965). Crosnier's

anomurans were subsequently studied by Dechancé (1964), for the Paguroidea, and by Haig (1966) and Haig \& Kropp (1987) for the Porcellanidae.

In 1964, during the ninth cruise of the R/V Anton Bruun, several stations (red squares on figure 1) were sampled in Mayotte region. The pontoniinid shrimps were studied by Bruce (1967, 1971) and a few Stomatopoda by Manning (1968). No anomurans were reported in the literature from this campaign, but it is possible that some specimens remain unstudied in the USNM collections, where the crustaceans of this campaign are deposited. 
In March and April, 1977, anomurans were collected in Mayotte region during the BENTHEDI campaign (Fig. 1). This campaign, conducted by Bernard Thomassin, aboard the IFREMER R/V Suroit, sampled stations from the vicinity of Mayotte, the Glorioso Islands, Geyser, Zélée and Leven Banks. The Crustacea are deposited in the MNHN collections. A brief description of this campaign is in Kornicker (1992) and station data is available online in the IFREMER web pages [2]. Forty one decapod species are currently known based on collections from the BENTHEDI campaign with 9 anomurans herein reported: of pylochelids in Forest (1987a) and McLaughlin \& Lemaitre (2009) (Cheiroplatea stenurus, Pomatocheles stridulans, Trizocheles hoensonae); of diogenids in Rahayu (2007) (Areopaguristes micheleae, Paguristes palythophilus, Pseudopaguristes laurentae); and of parapagurids in Lemaitre (1994, 2004a, b) (Paragiopagurus boletifer, Strobopagurus sibogae, Sympagurus dofleini).

Between 2006 and 2008, a few color photographs of anomurans have been made on the Geyser bank by one of us (V. Dinhut) and his colleagues, working for the ISURUS Cie. Species recognized on those photographs are Dardanus guttatus, Ciliopagurus tricolor, and, more interestingly, Aniculus maximus the bright yellow giant hermit crab reported here for the first time from Mayotte region (Fig. 13 A).

In 2008 and 2009, three marine biologists working for the Florida Museum of Natural History (UF) made collections in Mayotte region with specimens deposited in UF collections, Gainesville. Their work was part of the sampling effort realized in the area for the 2007-2010 ANR BIOTAS program in the WIO, coordinated by Henrich Bruggemann, Laboratoire d'Ecologie marine, Université de la Réunion (ECOMAR). A lists of stations and species were kindly transmitted by Arthur Anker and Machel Malay, with color photographs of the specimens. Only a few common species recognized with confidence have been integrated to this work, others specimens in UF collections being still unstudied.

Arthur Anker and François Michonneau have realized their collections in May-June 2008 in Mayotte with the following records: Calcinus latens, Calcinus morgani, Ciliopagurus tricolor, Coenobita rugosus, Dardanus megistos, Galathea spinosorostris, Galathea mauritiana.

Machel Malay was the UF member participating to the April-May 2009 BIOTAS campaign in the French 'Iles Eparses' on board the R/V Marion Dufresne (Fig. 5 A). The campaign has visited the islands of Europa, Juan de Nova, Glorioso Islands, and Tromelin. The team's objective was to conduct a preliminary survey of the invertebrates of these islands with special focus on coral symbionts. Within Mayotte region, the Glorioso Islands were visited between May 3-7, 2009. In total 22 anomurans were recognized satisfactorily from color photographs and have been integrated to this compilation (Aniculus retipes, Areopaguristes abbreviatus, Calcinus spp., Ciliopagurus tricolor, Clibanarius spp., Coenobita spp., Dardanus spp., Galathea tanegashimae, Pagurixus carinimanus, Petrolisthes lamarckii, and Polyonyx 
triunguiculatus). The most interesting record in this collection is Aniculus retipes, a large-sized species widespread in the IWP, recognized for the first time in Mayotte region (Fig. 13 B). Stations prospected by M. Malay and colleagues in Glorioso Islands are in appendix 1.

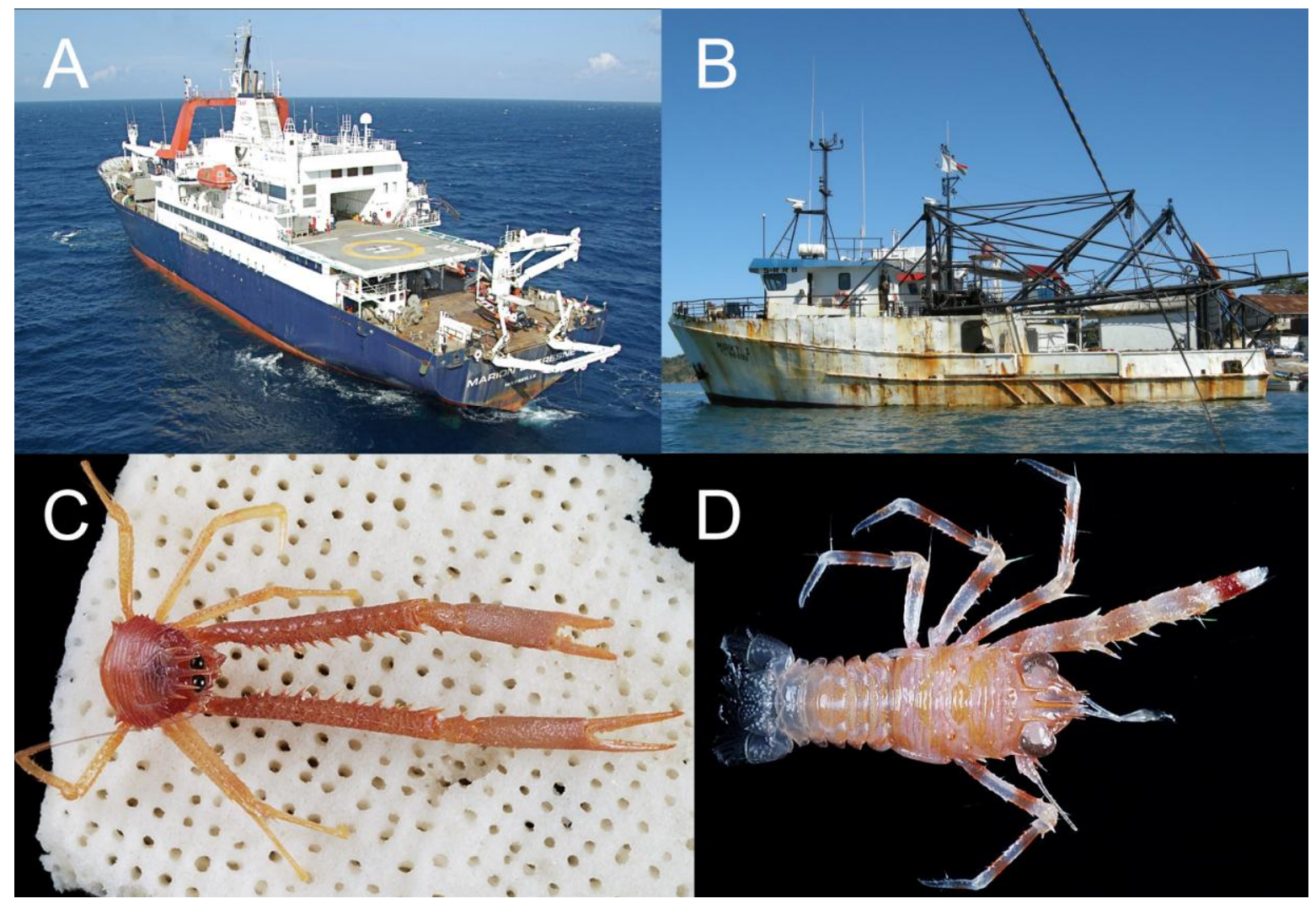

Figure 5. Two R/V that have contributed recently to the study of the anomurans of Mayotte region. A) R/V Marion Dufresne, en route to Mayotte Island in the Mozambique channel, 8 April 2011 (photo F. Fromard). This vessel is used to visit the French Iles Eparses, including Glorioso Islands. B) Shrimp trawler Miriky (photo A. Barrère) converted in R/V for the 2009 MIRIKY cruise organized by MNHN and PNI. Examples of anomurans dredged on the Leven bank by the R/V Miriky, 30 June 2009 (photos C.-W. Lin): C) Eumunida sp., St. DW3213,

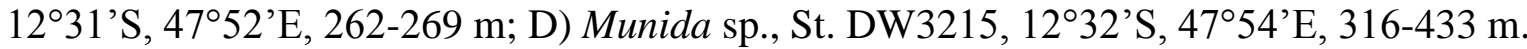

In June-July 2009, the MNHN and PNI organized an expedition to sample the sea floor between $100-1000 \mathrm{~m}$ in the extreme north of Madagascar. The expedition, conducted by Philippe Bouchet of the MNHN, took place on board the Miriky, a $24 \mathrm{~m}$ shrimp trawler belonging to a Nosy Be fisheries Cie (Fig. 5 B). The campaign is described on the MNHN 'Planet revisited' website [3]. Of the 110 dredging and trawling operations, 8 were conducted in Mayotte region on the Leven bank (green triangles in Fig. 1). The Miriky collection on the Leven bank includes a few Anomura that are still unstudied in MNHN (e.g., Eumunida sp. and Munida sp., Fig. 5). 


\section{DOCUMENTED CHECKLIST}

The classification of the Galatheidae adopted for this work is from Baba et al. (2008) with addition of the superfamily Chirostyloidea proposed by Schnabel et al. (2011) and the family Munididae proposed by Ahyong et al. (2010). Other taxa are listed according to classifications edited by Low \& Tan (2010) with a preamble and scope by McLaughlin et al. (2010a): Porcellanidae (Osawa \& McLaughlin, 2010), Hippoidea (Boyko \& McLaughlin, 2010) and Paguroidea (McLaughlin et al., 2010b). This classification is regularly updated in WoRMS Internet database [4].

Several records included herein were published in December 2009 in a report issued just after the KUW fieldwork (Bouchard et al., 2009). A few misidentifications in that report are herein corrected, with this presentation: Areopaguristes abbreviatus (Dechancé, 1963), 1 male S1 $2.1 \mathrm{~mm}$, Lt about $18 \mathrm{~mm}$, as 'Clibanarius sp. St. 32' in Bouchard et al., 2009: photo p. 96.

Species reported herein have been used for the inventory of the French overseas territories Poupin (2010) and in the WoRMS database [4] (search 'Checklist' with 'Mayotte Exclusive Economic Zone' and limit to 'Anomura').

ORDER DECAPODA

INFRAORDER ANOMURA

\section{SUPERFAMILY CHIROSTYLOIDEA}

FAMILY CHIROSTYLIDAE

\section{Eumunida sp.}

Eumunida sp. (Figure 5 C) - Leven bank, coll. MIRIKY campaign, St. DW3213, 30 June 2009, 12³1'S, 475'ㄹ, 262-269 m, MNHN.

Remarks. - Specimen under study by E. Macpherson, with others specimens collected during the 2009 MIRIKY campaign on the Leven bank (see historical overview of collections). 


\title{
SUPERFAMILY GALATHEOIDEA
}

\author{
FAMILY GALATHEIDAE
}

All Galatheidae records from Mayotte KUW fieldwork have been published separately by Macpherson \& Cleva (2010), including the description of a new genus and species Macrothea bouchardi. Geographic distributions listed below are from Baba et al. (2008) and Macpherson \& Baba (2010). All specimens were collected in the lagoon between 3-30 m, associated with various corals (e.g., Acropora, Pocillopora) or in coral heads. Before this inventory only two species were reported from the region, Galathea mauritiana (cf. Fourmanoir, 1955) and Galathea spinosorostris (cf. Baba, 1990).

\section{Galathea aegyptiaca Paul'son, 1875}

Galathea aegyptiaca (Figure 6 A-B) - Macpherson \& Cleva 2010: 58, Fig. 3a, b, Mayotte, KUW fieldwork November 2009, St. 12a, reef La Prévoyante, 6-11 m, coral bottom with Acropora, 2 ovigerous females 3.1-4.2 mm, MNHN-Ga7329; St. 21b, islet Choizil, 15-20 m, fringing reef and outer slope, 1 female $3.3 \mathrm{~mm}, \mathrm{MNHN}-$ Ga7330; St. 25, islet M'tzamboro, southern tip 15-20 m, accretions of coral blocks, 1 ovigerous female $3.6 \mathrm{~mm}$, MNHN-Ga7331; St. 30, reef Rani, 3-15 m, 2 males 3.5-4.7 mm, 2 ovigerous females 3.2-4.6 mm, MNHNGa7332; St. 32, islet M'tzamboro, north-east, 6-21 m, Acropora coral boulder, 1 male 3.8 mm, MNHN-Ga7333; St. 35, reef Surprise, Longoni pass, 4-25 m, reef slope, 1 female $3.6 \mathrm{~mm}$, MNHN-Ga7334.

Distribution. - IWP. Red Sea, Eastern Africa (South Africa), Madagascar, Mayotte (first record), Seychelles (Amirante, Saya de Mala bank), Mauritius (Cargados Carajos), Indonesia, Taiwan, Japan, Australia, Papua New Guinea, Loyalty Islands. Intertidal, between 1-30 m, with a single record at $146 \mathrm{~m}$.

Remarks. - A species commonly collected during the KUW fieldwork, between 3-30 m, on coral bottoms (mostly Acropora). Lt of the largest specimens, including chelae, is about 13-15 mm. Color pattern is helpful to recognize this species, specially for a red patch a base of fingers of chelae, a large brown median band on propodi of P2-P4, and an orange dot at tip of meri of P2-P4 (see Fig. 6 A-B).

\section{Galathea amamiensis Miyake \& Baba, 1966}

Galathea amamiensis - Macpherson \& Cleva 2010: 58, Mayotte, KUW fieldwork November 2009, St. 23, Choizil pass, 'Patate à Teddy', 15-30 m, outer reef, collapsed barrier, 1 ovigerous female 2.6 mm, MNHNGa7352.

Distribution. - IWP. Madagascar, Mayotte (first record), Indonesia, ?Australia, Japan. Subtidal to $50 \mathrm{~m}$. Between 15-30 $\mathrm{m}$ at Mayotte.

Remarks. - No color photograph of this species is available after KUW fieldwork. Live coloration is illustrated in Jones \& Morgan (2002: 135)

\section{Galathea denticulata Macpherson \& Cleva, 2010}

Galathea denticulata (Figure 6 C) - Macpherson \& Cleva, 2010: 59, fig. 1, 3e, Mayotte, KUW fieldwork November 2009, St. 9, 'S' pass, 0-20 m, submerged seagrass bed and coral slope of pass, $1 \mathrm{male} 2.2 \mathrm{~mm}$, as 'Galathea sp. St. 9' in Bouchard et al., 2009: photo p. 58, holotype, MNHN-Ga7338; St. 14, La Prudente bank, 15-17 m, coral boulders on sand bottom, 1 ovigerous female $2.3 \mathrm{~mm}$, paratype, MNHN-Ga7339.

Distribution. - Only Mayotte. Coral slope with branching corals and boulders, sand bottoms, between 0-20 m (Fig. 2 D).

Remarks. - New species described from KUW collections. It is related to Galathea amamiensis Miyake \& Baba, 1966, also collected during the fieldwork (see Macpherson \& Cleva, 2010: 61). 


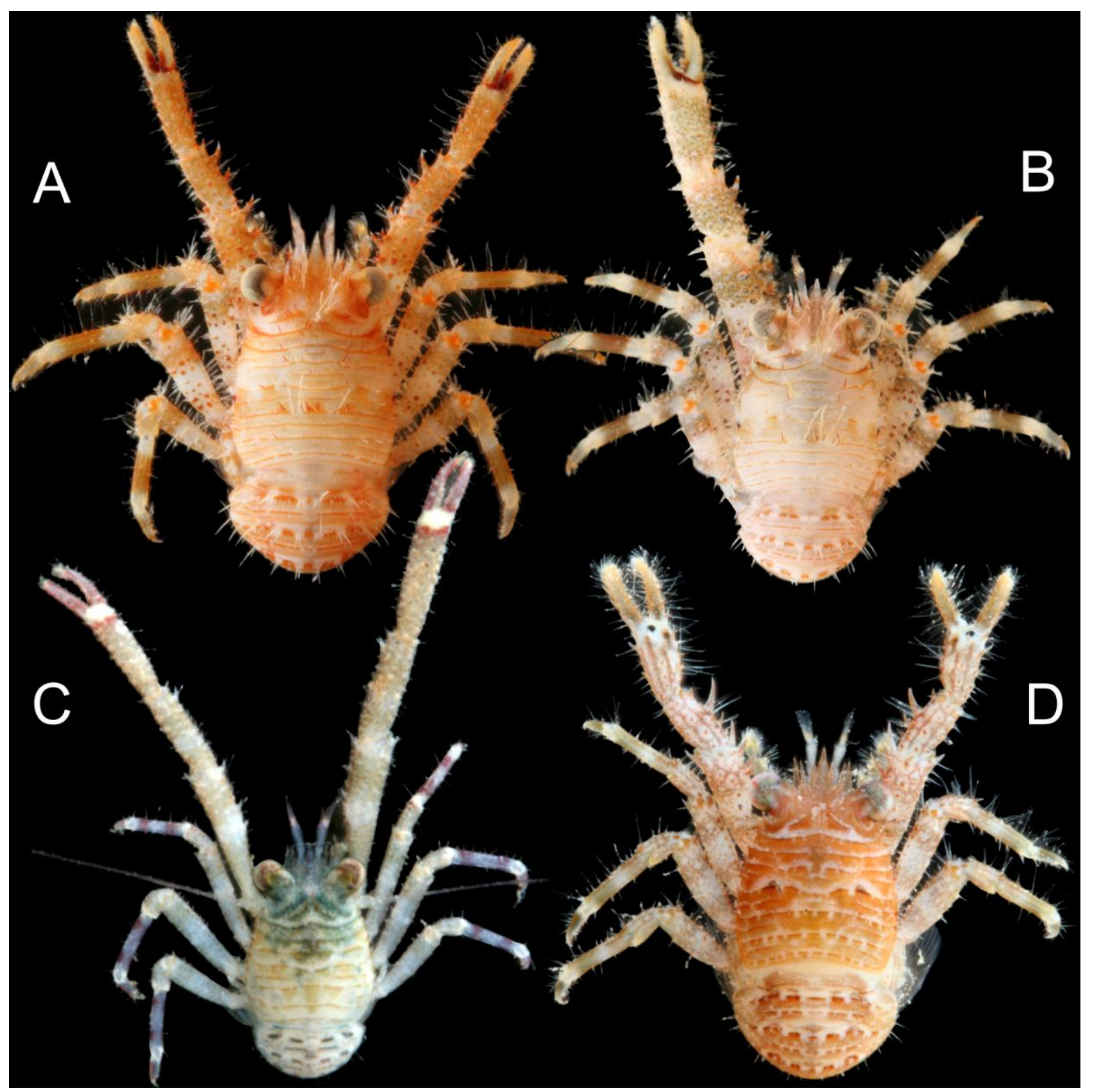

Figure 6. A-B) Galathea aegyptiaca. A) ovigerous female Lc $4.2 \mathrm{~mm}$, Lt about $13 \mathrm{~mm}$, Mayotte, St. 12, MNHN-Ga7329; B) 1 male Lc 3.8 mm, Mayotte, St. 32, MNHN-Ga7333. C) Galathea denticulata, 1 male holotype, Lc $2.2 \mathrm{~mm}$, Lt about $12 \mathrm{~mm}$, Mayotte, St. 9, MNHNGa7338. D) Galathea mauritiana, 1 ovigerous female, Lc $3.2 \mathrm{~mm}$, Lt about $12 \mathrm{~mm}$, Mayotte, St. 12, MNHN-Ga7335. 


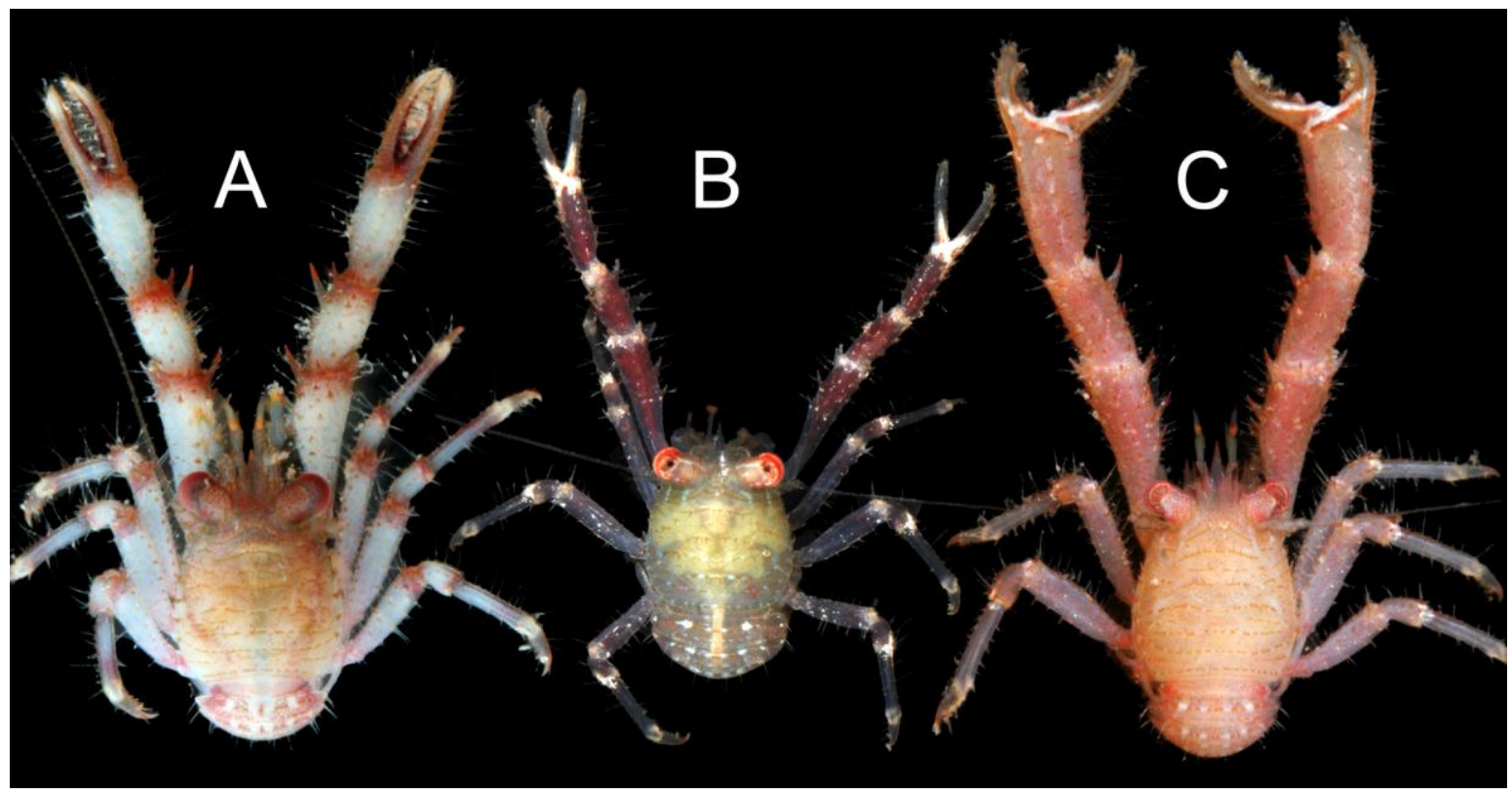

Figure 7. A) Galathea spinosorostris, 1 male Lc $3.2 \mathrm{~mm}$, Lt with chelae about $12 \mathrm{~mm}$, Mayotte, St. 23, MNHN-Ga7340. B-C) Galathea tanegashimae. B) Glorioso, specimen MEPA 974 (photo BIOTAS team, courtesy M. Malay); C) 1 ovigerous female Lc $3.7 \mathrm{~mm}$, Lt with chelae about 20mm, Mayotte, St. 14, MNHN-Ga7342.

\section{Galathea mauritiana Bouvier, 1915}

Galathea mauritiana (Figure 6 D) - Fourmanoir, 1955: 30 (Mayotte, barrier reef). - Coll. Anker \& Michonneau, 2008, St. MAY08-St2, Tanaraki reef, UF 13556. - Macpherson \& Cleva 2010: 59, Fig. 3c, d, Mayotte, KUW fieldwork November 2009, St. 12a, reef La Prévoyante, 6-11 m, coral bottom with Acropora, 1 ovigerous female 3.2 mm, MNHN-Ga7335; St. 14, La Prudente bank, 15-17 m, coral boulders on sand bottom, 1 male 3.8 mm, MNHN-Ga7336; St. 17, North Reef, $22 \mathrm{~m}$, outer reef, coral boulders on sand bottom, 2 ovigerous female 2.2-2.7 mm, MNHN-Ga7337. - Galathea affinis - Baba, 1990: 953 (Mayotte, North reef, $20 \mathrm{~m}$, coll. ?Crosnier April 1959, 3 males 4.2-5.3 mm, 1 ovigerous female $4.9 \mathrm{~mm}$, MNHN (Galathea affinis Ortmann, 1892 is a junior synonym of G. mauritiana).

Distribution. - IWP. Red Sea, Eastern Africa (Tanzania, Zanzibar), Madagascar, Mayotte, Seychelles, Réunion, Mauritius, Chagos, Indonesia, Taiwan, Japan, New Guinea, Loyalty Islands, Fiji, Wallis \& Futuna, French Polynesia. Intertital to $48 \mathrm{~m}$. Collected at Mayotte between 0-22 m.

Remarks. - Galathea mauritiana is very common in the intertidal, among rubble. The presence of a black spot on the upper face of its chelae, at base of fingers, is a good mean to recognize it quickly (see. Fig. 6 D). 


\section{Galathea spinosorostris Dana, 1852}

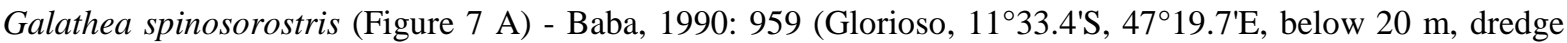
January 1973, coll. C. Jouannic, 6 males 2.9-4.6 mm, MNHN; Mayotte, 30 m, ?coll. A. Crosnier, September 1959, 1 male 3.4 mm, MNHN). - Coll. Anker \& Michonneau, 2008, St. MAY08-St2, Tanaraki reef, UF 13580; St. MAY08-St6, 'S' pass, UF 13653. - Macpherson \& Cleva, 2010: 62, Fig. 3f, Mayotte, KUW fieldwork November 2009, St. 23, Choizil pass, 'Patate à Teddy', 15-30 m, outer reef, collapsed barrier, 1 male $3.2 \mathrm{~mm}, 1$ ovigerous female $3.4 \mathrm{~mm}$, MNHN-Ga7340.

Distribution. - IWP. Red Sea, Eastern Africa (Zanzibar), Madagascar, Mayotte, Glorioso, Seychelles, Réunion, Mauritius, Indonesia, Singapore, South China Sea, Japan, Philippines, Palau, French Polynesia, Hawaii. Collected at Mayotte from intertidal reef to $30 \mathrm{~m}$.

Remarks. - First attributed to G. aff. spinosorostris in KUW fieldwork the specimens were considered to represent G. spinosorostris by Macpherson \& Cleva (2010). These authors recommend a revision of material from different localities because of the unusual depth range of this species $(1.5-772 \mathrm{~m})$.

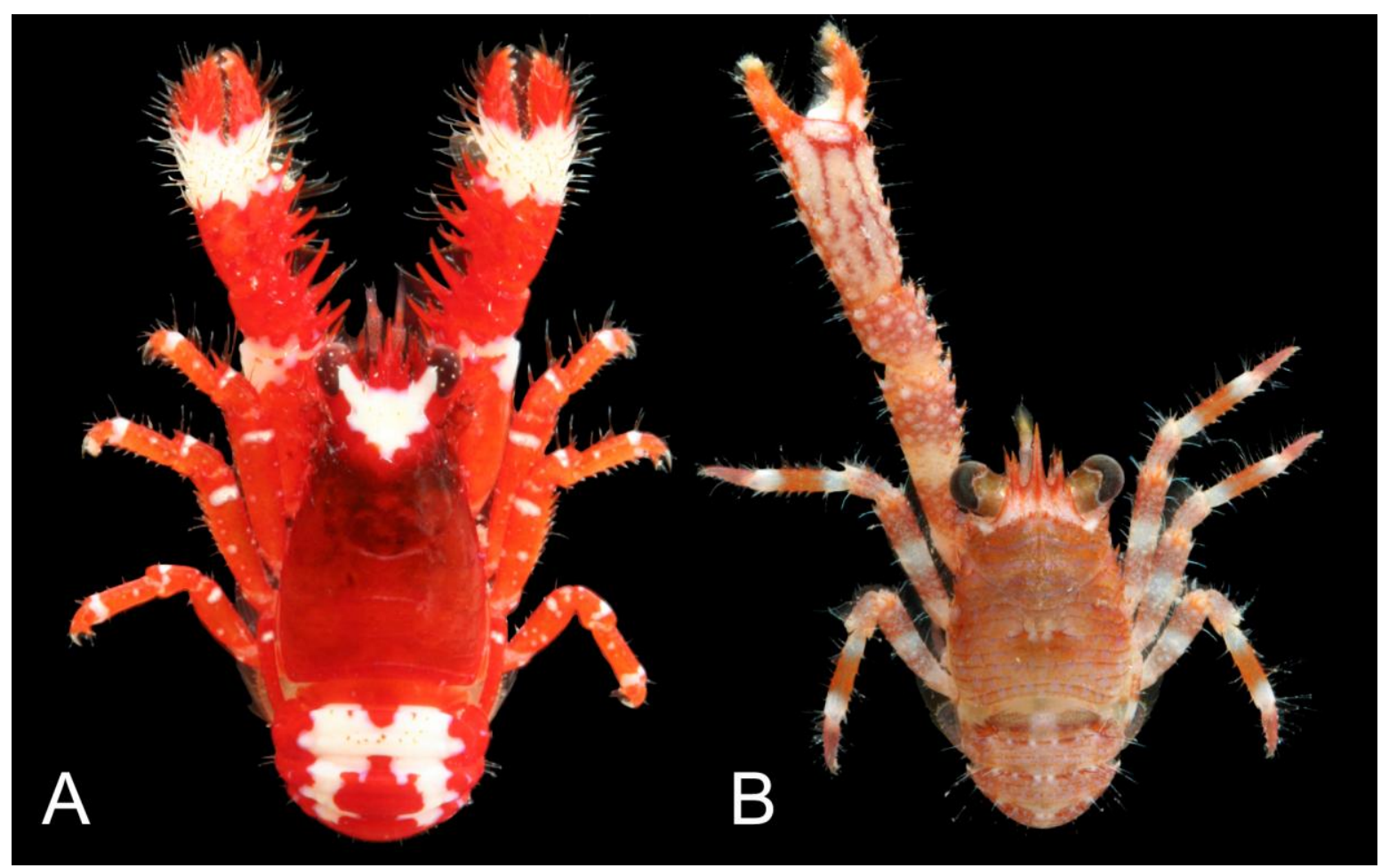

Figure 8. A) Macrothea bouchardi, holotype male Lc $3.5 \mathrm{~mm}$, Lt with chelae about $10 \mathrm{~mm}$, Mayotte, St. 23, MNHN-Ga7350. B) Sadayoshia edwardsii, right cheliped missing, 1 male Lc $4.6 \mathrm{~mm}$, Lt with chela about $21 \mathrm{~mm}$, Mayotte, St. 23, MNHN-Ga7351. 


\section{Galathea tanegashimae Baba, 1969}

Galathea tanegashimae (Figure 7 B-C) - BIOTAS collections, Glorioso, 3-7 May 2009, det. J. Poupin from photo, St. GLOR-2, reef platform and shallow canyons with dead Acropora digitifera head, 7-14 m, specimen MEPA 974. - Macpherson \& Cleva, 2010: 62, fig. 3g-h, Mayotte, KUW fieldwork November 2009, St. 12a, reef La Prévoyante, coral bottom with Acropora, 1 male $1.8 \mathrm{~mm}, 1$ ovigerous female $2.5 \mathrm{~mm}, 1$ female $2.1 \mathrm{~mm}$, as 'Galathea sp. St. 12' in Bouchard et al., 2009: photo p. 58, MNHN-Ga7341; St. 14, La Prudente bank, 15-17 $\mathrm{m}$, coral boulders on sand bottom, 5 males $2.0-4.3 \mathrm{~mm}, 2$ ovigerous females 3.0-3.7 mm, 1 female $2.7 \mathrm{~mm}$, as 'Galathea sp. St. 14' in Bouchard et al., 2009: photo p. 58, MNHN-Ga7342; St. 17, North Reef, 22 m, outer reef, coral boulders on sand bottom, 3 males 2.0-4.2 mm, 7 ovigerous females 2.1-4.0 mm, MNHN-Ga7343; St. 20b, islet M'tzamboro, western reef, 10-15 m, near collapsed reef, steep sand slope, 1 ovigerous female $2.4 \mathrm{~mm}$, MNHN-Ga7344; St. 21b, islet Choizil, east of Malandzamiayatsini, 15-20 m, fringing reef and outer slope, 1 male 3.4 mm, MNHN-Ga7345; St. 23, Choizil pass, 'Patate à Teddy', 15-30 m, outer reef, collapsed barrier, 1 male $2.7 \mathrm{~mm}, 1$ ovigerous female $2.1 \mathrm{~mm}$, MNHN-Ga7346; St. 25, islet M'tzamboro, southern tip, 15-20 m, slope with accretions of coral blocks, 2 males 3.1-3.2 mm, MNHN-Ga7347; St. 28, islet Mbouini, east, 3-20 m, high tide, outer reef and slope, 1 male $2.7 \mathrm{~mm}$, MNHN-Ga7348; St. 32, islet M'tzamboro, north east, 6-21 m, huge Acropora coral boulder, 1 ovigerous female $2.9 \mathrm{~mm}$, MNHN-Ga7349.

Distribution. - IWP. Eastern Africa (Somalia, Zanzibar), Mayotte and Glorioso (first record), Taiwan, Japan, Lord Howe. Collected in Mayotte in coral Acropora and coral blocks, between 3-30 m, reported between 10$165 \mathrm{~m}$.

Remarks. - Although at the beginning of this study a few lots were suspected to be G. spinosorostris, these all proved to represent $G$. tanegashimae. Galathea tanegashimae can be recognized by the special ' $\mathrm{X}$ ' shaped white patch at base of fingers of chelae (see Fig. 7 B-C). This character was used to identify the specimens collected in the Glorioso during the BIOTAS expedition (Fig. 7 B, sp. MEPA 974, probably in UF).

\section{Macrothea bouchardi Macpherson \& Cleva 2010}

Macrothea bouchardi (Figure 8 A) - Macpherson \& Cleva, 2010: 63, fig. 2, 3k, Mayotte, KUW fieldwork November 2009, St. 23, Choizil pass, 'Patate à Teddy', 15-30 m, outer reef, collapsed barrier, 1 male 3.5 mm, as 'Galathea sp. St. 23' in Bouchard et al., 2009: photo p. 58 (middle, left), holotype, MNHN-Ga7350.

Distribution. - WIO. Mayotte, 15-30 m and Madagascar, 75-77 m.

Remarks. - Live coloration of this new genus and species is available from a photograph taken during the KUW fieldwork (Fig. 8 A).

\section{FAMILY MUNIDIDAE}

\section{Munida sp.}

Munida sp. (Figure 5 D) - Leven bank, coll. MIRIKY campaign, St. DW3215, 30 June 2009, 12³2'S, 4754'E, 316-433 m, MNHN.

Remarks. - Specimen under study by E. Macpherson along with others specimens collected during the 2009 MIRIKY campaign on the Leven bank (see historical overview of collections).

\section{Sadayoshia edwardsii (Miers, 1884)}

Sadayoshia edwardsii (Figure 8 B) - Macpherson \& Cleva, 2010: 67, fig. 31, Mayotte, KUW fieldwork November 2009, St. 23, Choizil pass, 'Patate à Teddy', 15-30 m, outer reef, collapsed barrier, 1 male 4.6 mm, as 'Galathea sp. St. 23' in Bouchard et al., 2009: photo p. 58 (bottom, left), MNHN-Ga7351.

Distribution. - IWP. Mozambique channel, Madagascar, Mayotte (first record), Seychelles (Aldabra, Amirante), Réunion, Mauritius, Bay of Bengal, Indonesia, Japan, Philippines, Marianas, Palau, Line Islands, New Caledonia, Loyalty Islands, Vanuatu, French Polynesia. Sublittoral between 3-90 m, Mayotte specimen collected between 15-30 m. 
Remarks. - The genus Sadayoshia has been revised recently by Macpherson \& Baba (2010) with additions of four new species. Sadayoshia edwardsii is one of the commonest species with a wide IWP distribution. It is usually associated with corals Pocilloporidae such as Seriatopora hystrix. Typical coloration of the species includes purple spots along transverse ridges of the carapace but these are not very clear on the specimen

photographed from Mayotte (Fig. 8 B). The cheliped has white patches on merus and carpus, and longitudinal reticulations on upper face of the palm, as visible on Fig. 8B.

\section{FAMILY PORCELLANIDAE}

The Porcellanidae of Mayotte region were studied by Haig (1966) based on collections made by researchers working at ORSTOM Madagascar (M. Chavane, A. Crosnier, P. Fourmanoir and J. Millot) between 1955 and 1962 and deposited in MNHN. Haig (1983) has also studied a collection of Porcellanidae from the Seychelles. In addition to the 13 porcelainlike crabs of the present list, Haig (1966: 40) mentioned a Petrolisthes sp. from Mayotte (Saziley pass, $10 \mathrm{~m}$, coral, coll. A. Crosnier, September 1959). She indicated that this unique specimen, in poor condition "appartient vraisemblablement à une espèce nouvelle dont nous avons examiné des échantillons provenant du Pacifique occidental et que nous nous proposons de décrire dans un travail à venir". However, it appears that Haig never published the description. A key for determination of WIO porcelain-like crabs can be found in Haig (1966: 46). In addition, Osawa (2007a) published a key to IWP genera and species of Porcellanidae.

\section{Aliaporcellana pygmaea (De Man, 1902)}

Aliaporcellana pygmaea (Figure 10 A) - Mayotte, KUW fieldwork November 2009, St. 14, La Prudente bank, 15-17 m, 1 ovigerous female $2.41 \times 2.41 \mathrm{~mm}$, MNHN-Ga7460; St. $21 \mathrm{~b}$, islet Choizil, east, $15-20 \mathrm{~m}, 1$ ovigerous female $3.27 \times 3.35$ mm, MNHN-Ga7461; St. 23, Choizil pass 'Patate à Teddy', 15-30 m, 1 male $2.68 \times 2.55$ mm, MNHN-Ga7462.

Distribution. - IWP. Red Sea, Madagascar, Mayotte (first record), Seychelles, Cargados Carajos, Siam Gulf, Indonesia, New Caledonia, Loyalty Islands; between 5-80 m. Mayotte specimens collected between 15-30 m.

Remarks. - A small-sized porcellanid living on coral or sponges. The genus Aliaporcellana includes four species. Osawa's (2007a: 5) key was used to determined the three specimens collected at Mayotte. Live coloration of Aliaporcellana pygmaea is available for Taiwan (see Osawa \& Chan, 2010: 79, fig. 51-52). Aliaporcellana pygmaea can be can be recognized from A. suluensis (Dana, 1852), also in the Indian Ocean, by the presence of an epibranchial spine (absent in A. suluensis), 3 branchial spines (four in A. suluensis), and by a mobile spine on the ventral margin of the dactyl of the ambulatory legs (missing in A. suluensis).

\section{Neopetrolisthes maculatus (H. Milne Edwards, 1837)}

Neopetrolisthes maculatus (Figure 9 A) - Mayotte, KUW fieldwork November 2009, St. 5, Great north-eastern reef, seagrass bed, $1 \mathrm{~m}, 1$ male $12.41 \times 10.07 \mathrm{~mm}$, MNHN-Ga7435.

Distribution. - IWP. Red Sea, Eastern Africa, Madagascar, Mayotte (first record), Réunion, Christmas Island, Taiwan, Japan, Australia, New Guinea, Marshall, Fiji. This distribution must be revised when the status of $N$. maculatus and N. ohshimai are more clear (see Remarks).

Remarks. - A medium-sized porcelain crab always associated with giant sea-anemones (genera Cryptodendrum, Entacmaea, Stichodactyla). It seems common in Mayotte with several in situ photographs transmitted by collaborators (e.g. Fig. 9 A) or available on Internet (DORIS [5], photo S. Grilhe). Neopetrolisthes ohshimai Miyake, 1937, with fewer and larger spots on the carapace is considered as a distinct sibling species by Poupin \& Juncker (2010), but as a junior synonym by Osawa \& Chan (2010). 


\section{Pachycheles sculptus (H. Milne Edwards, 1837)}

Pachycheles sculptus (Figure 9 C-D) - Mayotte, KUW fieldwork November 2009, St. 25, islet M'tzamboro, 15$20 \mathrm{~m}, 1$ female $2.93 \times 3.76 \mathrm{~mm}, \mathrm{MNHN}-\mathrm{Ga} 7463$.

Distribution. - IWP. Mayotte (first record), Seychelles, Mergui archipelago, Malaysia, Indonesia, Hong Kong, Taiwan, Japan, Australia, New Caledonia, French Polynesia (Tuamotu). Littoral to $180 \mathrm{~m}$.

Remarks. - This species has affinities with Pachycheles natalensis (Krauss, 1843), distributed in the WIO only. Lewinsohn (1979: 50) has speculated that $P$. sculptus (H. Milne Edwards, 1837) was not present in the Indian Ocean until Haig (1983: 284) recorded it from the Seychelles. The specimens from Mayotte is attributed to $P$. sculptus based on its live coloration (compare Fig. 9 C-D) and by the presence of four tuberculated longitudinal lines on the outer face of the larger chela. In the key of the genus by Osawa (2007a: 19) it is indicated that males of both species can be separated by the presence ( $P$. sculptus) or absence (P. natalensis) of pleopods.

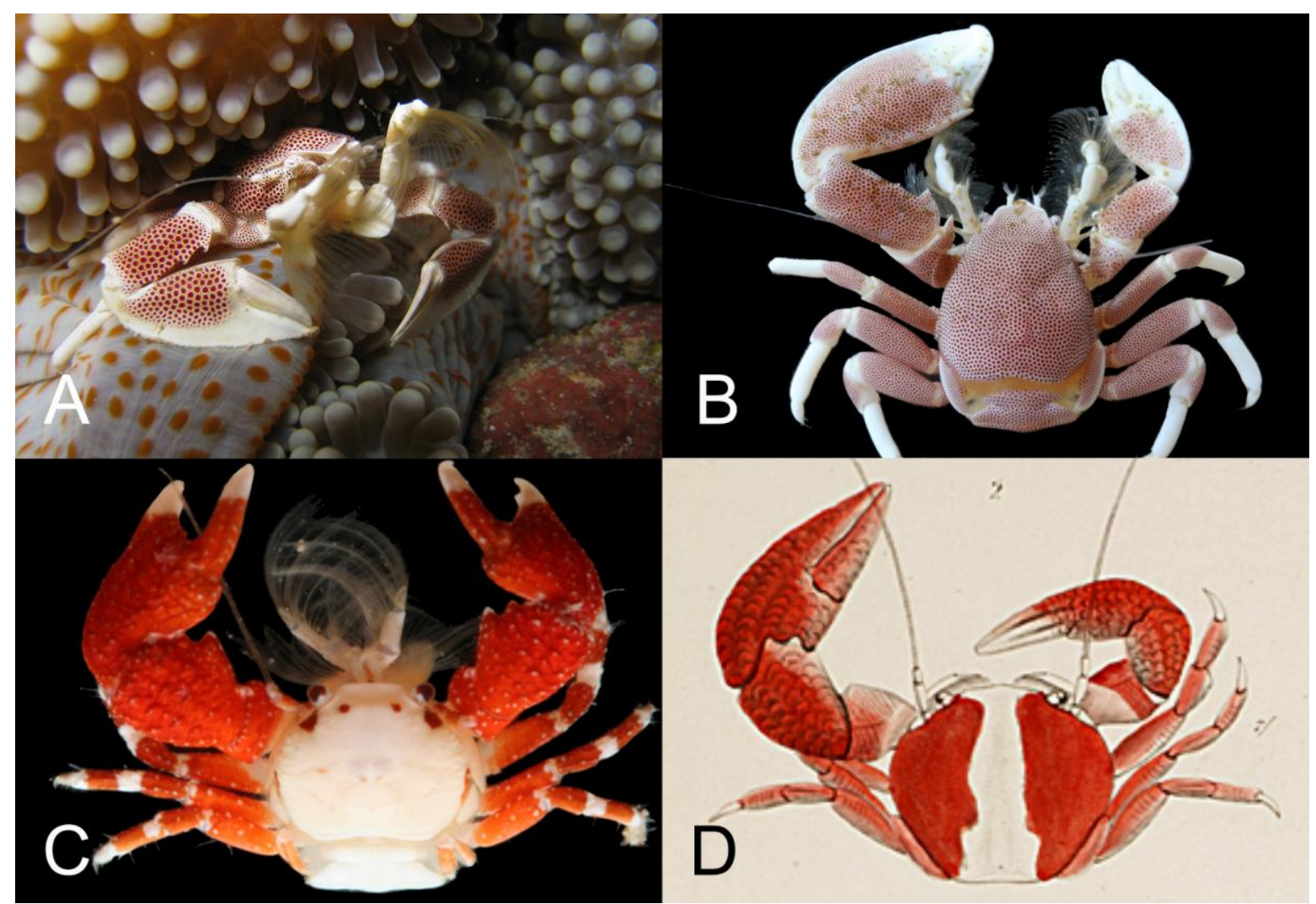

Figure 9. A-B) Neopetrolisthes maculatus. A) In situ photographs by M. Deuss, Mayotte, Buoy '4' 'S' pass, 15 m. Copyright M. Deuss; B) 1 male $12.41 \times 10.07 \mathrm{~mm}$, Mayotte, St. 5, MNHNGa7435. C-D) Pachycheles sculptus. C) 1 female $2.93 \times 3.76 \mathrm{~mm}$, Mayotte, St. 25, MNHNGa7463; D) color pattern as illustrated by Dana (1855, pl. 26, fig. 2). 


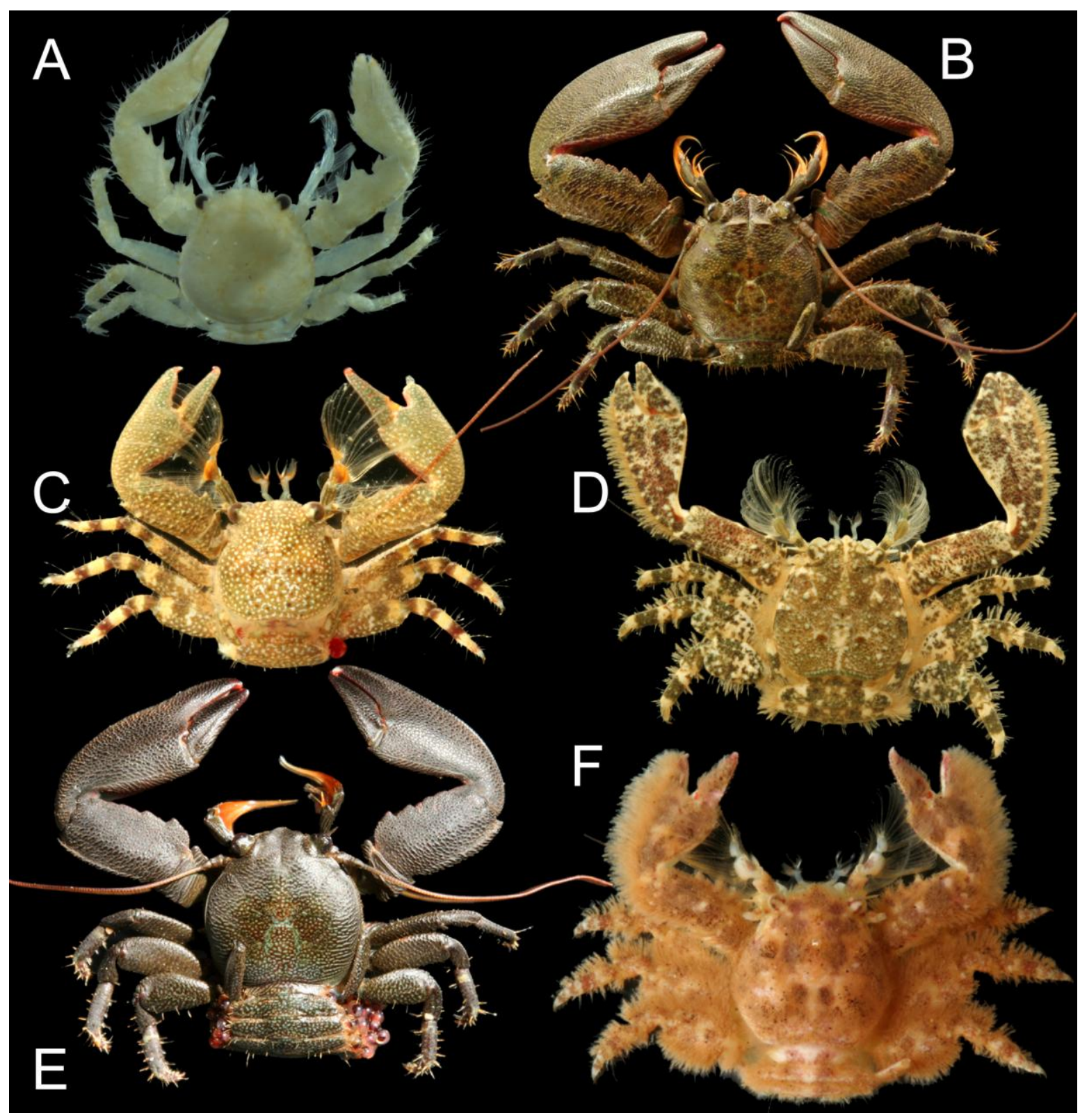

Figure 10. A) Aliaporcellana pygmaea, 1 ovigerous female $2.41 \times 2.41 \mathrm{~mm}$, Mayotte, St. 14 , MNHN-Ga7460, coloration altered by preservative. B-C) Petrolisthes lamarckii. B) 1 male $12.6 \times 11.75 \mathrm{~mm}$, Mayotte, St. 29, MNHN-Ga7457; C) 1 ovigerous female $3.65 \times 3.5 \mathrm{~mm}$, Mayotte, St. 29, MNHN-Ga7458. D) Petrolisthes ornatus, 1 female 7.0x6.69 mm, Mayotte, St. 29, MNHN-Ga7444. E) Petrolisthes rufescens, 1 ovigerous female $7.14 \times 7.33 \mathrm{~mm}$, Mayotte, St. 6, MNHN-Ga7447. F) Petrolisthes tomentosus, 1 female $6.2 \times 6.0 \mathrm{~mm}$, Mayotte, St. 26, MNHNGa7510. 


\section{Petrolisthes decacanthus Ortmann, 1897}

Petrolisthes decacanthus - Haig \& Kropp, 1987: 179, Glorioso Islands, Grande Glorieuse, intertidal, coll. A. Crosnier 30 January 1971, 2 females (AHF 2734-01).

Distribution. - IWP. Glorioso, Seychelles, Maldives, Taiwan, Mariana, Caroline, Palau, Marshall, Samoa, Society Islands.

Remarks. - Living coloration of this species is available in Osawa \& Chan (2010: 127, fig. 94).

\section{Petrolisthes lamarckii (Leach, 1820)}

Petrolisthes lamarckii (Figure 10 B-C) - Fourmanoir, 1955: 30 (Comoros: Mayotte, Mohéli, Grande Comore, 1.5-2.5 m). - Haig, 1966: 41 (Mayotte, Bandéli, coll. A. Crosnier, September 1959, intertidal, 1 ovigerous female $7.2 \mathrm{~mm}, 1$ female $4.4 \mathrm{~mm}$; Glorioso, intertidal, coll. Millot and Crosnier, 16 September 1958, intertidal, 1 female $7.6 \mathrm{~mm}, 2$ ovigerous females 7.2 and $11.2 \mathrm{~mm}$, MNHN). - BIOTAS collections, Glorioso, 3-7 May 2009, det. J. Poupin from photo, St. GLOR-13, in front of Military camp, 'Îlot aux crabes', intertidal, MEPA 1345. - Mayotte, KUW fieldwork November 2009, St. 2, intertidal, from Trévani to Kangani mangrove, 1 male $8.74 \times 8.37 \mathrm{~mm}$, as 'Porcellana sp. St. 2' in Bouchard et al., 2009: photo p. 59, MNHN-Ga7450, 7 males $6.77 \times 6.43$ to $8.35 \times 7.94 \mathrm{~mm}, 1$ ovigerous female $7.19 \times 6.77 \mathrm{~mm}$, MNHN-Ga7451; St. 6, Petite Terre, Badamiers spillway, intertidal, 1 ovigerous female $7.63 \times 7.21 \mathrm{~mm}$, MNHN-Ga7452, 2 males $7.0 \times 6.5$ and $8.08 \times 7.67 \mathrm{~mm}, 1$ ovigerous female $7.89 \times 7.66 \mathrm{~mm}$ as 'Porcellana sp. St. 6' in Bouchard et al., 2009: photo p. 59, MNHNGa7453; St. 10, islet Quatre Frères, intertidal, 1 male, 2 ovigerous females, MNHN-Ga7454; St. 26, Mutsumbatsou reef flat, intertidal, 1 male $3.61 \times 3.30 \mathrm{~mm}$, MNHN-Ga7455, 4 males $3.9 \times 3.53$ to $7.32 \times 7.08 \mathrm{~mm}$, 2 ovigerous females $5.33 \times 5.48$ and $6.14 \times 5.69 \mathrm{~mm}$, as 'Porcellanidae indeterminé St. 26' in Bouchard et al., 2009: photo p. 60 (top, right), MNHN-Ga7456; St. 29, Ngouja hotel, Mboianatsa beach, intertidal, 1 ovigerous female $3.65 \times 3.50 \mathrm{~mm}$ as 'Porcellanidae indeterminé St. 29' in Bouchard et al., 2009: photo p. 60, MNHNGa7458, 6 males $6.66 \times 6.11$ to $12.60 \times 11.75$, as 'Porcellana sp. St. 29' in Bouchard et al., 2009: photo p. 59, MNHN-Ga7457.

Distribution. - Widespread in the IWP. Red Sea, eastern Africa (Kenya, Somalia, Natal, Tanzania), Comoros (Mayotte, Mohéli, Grande Comore), Glorioso, Madagascar, Seychelles, Mauritius, Chagos, Nicobar, Malaysia, Indonesia, Taiwan, Japan, Australia, New Caledonia, Wallis \& Futuna, French Polynesia.

Remarks. - Petrolisthes lamarckii is very common in the intertidal area at Mayotte. It can be collected and confused with Petrolisthes rufescens (compare Fig. 10 B-C, E). Petrolisthes lamarckii is distinct by: a) a more variable color, with patches on the carapace and a transverse median red-maroon band on propodi of ambulatory legs (color variations illustrated on Fig. 10 B-C and also in Osawa \& Chan, 2010: 142-143); b) distal outer margin of carpus of cheliped with 2-3 spines (absent in P. rufescens); c) presence of an epibranchial spine on the carapace (absent in P. rufescens).

\section{Petrolisthes ornatus (Paul'son, 1875)}

Petrolisthes ornatus (Figure 10 D) - Fourmanoir, 1955: 30 (Mayotte, Bandéli, 1.5 m). - Haig, 1966: 41 (Mayotte, Bandéli, coll. A. Crosnier, September 1959, intertidal, 3 males 6.0 to $7.2 \mathrm{~mm}, 7$ females 5.5 to 6.3 mm, MNHN). - Mayotte, KUW fieldwork November 2009, St. 6, Petite Terre, Badamiers spillway, intertidal, 1 male $6.07 \times 5.62 \mathrm{~mm}, \mathrm{MNHN}-\mathrm{Ga} 7442$; St. 26, Mutsumbatsou reef flat, intertidal, 1 ovigerous female $6.61 \times 6.33$ mm, MNHN-Ga7443; St. 29, Ngouja hotel, Mboianatsa beach, intertidal, 1 female $7.0 \times 6.69 \mathrm{~mm}$, as 'Porcellanidae indeterminé St. 29' in Bouchard et al., 2009: photo p. 60, MNHN-Ga7444; St. 31, Brandélé 'Musical beach', intertidal, 1 male 2.93×2.52 mm, MNHN-Ga7445.

Distribution. - WIO. Red Sea, eastern Africa (Tanzania), Comoros, Mayotte, Madagascar, Sri Lanka.

Remarks. - In this species the inner face of fingers of chelae is setiferous, forming a brush of setae, and the outer margin of the chelae is fringed with long setae ( $c f$. Fig. 10 D). Carapace and ambulatory legs are covered with tubercles, reduced on the smallest specimens. 


\section{Petrolisthes rufescens (Heller, 1861)}

Petrolisthes rufescens (Figure 10 E) - Haig, 1966: 41 (Mayotte, Bandéli, coll. A. Crosnier, intertidal, 1 female $5.2 \mathrm{~mm}, \mathrm{MNHN}$ ). - Mayotte, KUW fieldwork November 2009, St. 2, from Trévani to Kangani mangrove, intertidal, 2 males $6.31 \times 6.31$ and $8.80 \times 9.07 \mathrm{~mm}, 1$ ovigerous female $8.63 \times 8.98 \mathrm{~mm}$, MNHN-Ga7446; St. 6 , Petite Terre, Badamiers spillway, 0-1 m, 2 males $6.46 \times 6.34$ and $7.39 \times 7.39 \mathrm{~mm}, 3$ ovigerous females $6.74 \times 6.79$ to $7.14 \times 7.33 \mathrm{~mm}$, as 'Porcellana sp. St. 6' in Bouchard et al., 2009: photo p. 59, 1 female 6.57×6.73, MNHNGa7447; St. 10, islet Quatre Frères, intertidal, 4 males and 1 ovigerous female, MNHN-Ga7448; St. 26, Mutsumbatsou reef flat, intertidal, 4 males $3.66 \times 3.49$ to $6.38 \times 6.27 \mathrm{~mm}, 2$ ovigerous females $3.94 \times 3.88$ and $5.64 \times 5.83 \mathrm{~mm}, \mathrm{MNHN}-\mathrm{Ga} 7449$.

Distribution. - WIO. Red Sea, Gulf of Aden, eastern Africa (Kenya, Mozambique, Somalia, Tanzania, Zanzibar), Mayotte, Madagascar, Mauritius.

Remarks. - This species is distributed in WIO only. It has been sometimes considered as a junior synonym of Petrolisthes lamarckii, widely distributed in the IWP, but both species are clearly separated by Haig (1966, 1983). In addition to the characters mentioned under P. lamarckii to tell both species apart, it has been observed, in specimens of $P$. rufescens from KUW St. 2, that the inner face of the chela bears a low tomentum, not observed in P. lamarckii.

\section{Petrolisthes tomentosus (Dana, 1852)}

Petrolisthes penicillatus - Haig, 1966: 42 (Comoros: Anjouan, coll. A. Crosnier, November 1961, intertidal, 1 male $6.5 \mathrm{~mm}, 2$ ovigerous females 4.5 et $6.3 \mathrm{~mm}$; Glorioso intertidal, 16 September 1958, coll. Millot, 4 males 2.7 to $6.6 \mathrm{~mm}, 2$ females 5.8 and $8.5 \mathrm{~mm}, 4$ ovigerous females 4.6 to $6.5 \mathrm{~mm}$, MNHN). - Petrolisthes tomentosus (Fig. 10 F) - Mayotte, KUW fieldwork November 2009, St. 26, Mutsumbatsou reef flat, intertidal, 1 female $6.2 \times 6.0 \mathrm{~mm}$, as 'Porcellanidae indeterminé St. 26' in Bouchard et al., 2009: photo p. 60 (bottom, left), MNHN-Ga7510, 3 males $5.05 \times 4.73$ to $6.18 \times 5.67 \mathrm{~mm}, 4$ ovigerous females $5.04 \times 4.63$ to $5.62 \times 5.92 \mathrm{~mm}, 2$ females $4.22 \times 4.18$ and $5.59 \times 5.23 \mathrm{~mm}$, MNHN-Ga7511.

Distribution. - IWP. Eastern Africa (Somalia), Comoros (Anjouan), Mayotte, Glorioso, Madagascar, Seychelles, Mauritius, Nicobar, western Australia, Palau, Japan, Marianas, Guam, Fiji, French Polynesia (Tahiti).

Remarks. - Following Kropp (1986: 453) Petrolisthes penicillatus (Heller, 1861) is now considered as a junior synonym of Petrolisthes tomentosus (Dana, 1852). This synonymy is accepted here with some hesitation because Mayotte specimens differ slightly from western Pacific specimens as defined by Osawa (2007a: 22, key). In Mayotte specimens the armature of extensor (dorsal) margin of meri of P2 and P3 is limited to 1-2 distal spines and spines are absent on P4 margin. In western Pacific specimens there is a 'row of spines' on extensor margins of meri of $\mathrm{P} 2, \mathrm{P} 3$, and $\mathrm{P} 4$. The reduction in number of spines on extensor margin of meri of ambulatory legs in Mayotte specimens is in accordance with that of the types specimens of P. penicillatus from Nicobar Islands: 2, 2, and 1 spine, respectively on P2, P3, and P4, as reported by Lewinsohn (1979: 48). Lewinsohn (1979) mentions that additional specimens examined from Somalia are similar to types specimens of $P$. penicillatus. Therefore, the possibility exists that $P$. tomentosus as accepted nowadays includes in fact two distinct species, one in the Indian Ocean, corresponding to $P$. penicillatus Heller, and one in the Pacific for $P$. tomentosus.

Observations made for this study show that the specimen attributed with hesitation to P. tomentosus from la Réunion by Poupin (2009: 124; with photograph in Internet database [6]) is more probably Petrolisthes pubescens Stimpson, 1858, a species that has affinities with $P$. tomentosus, distributed from Red Sea, Mauritius to New Caledonia and the Marquesas. A good color photograph of P. pubescens is in Osawa \& Chan (2010: 155 , fig. 121) with live coloration similar to la Réunion' specimen.

\section{Pisidia delagoae (Barnard, 1955)}

Pisidia delagoae - Haig, 1966: 43, fig. 1 (Glorioso, coll. Millot, intertidal, 16 September 1958, 1 ovigerous female $2.6 \mathrm{~mm}$ ).

Distribution. - WIO. Eastern Africa (Somalia, Mozambique), Glorioso. 


\section{Polyonyx biunguiculatus (Dana, 1852)}

Polyonyx biunguiculatus (Figure 11 A) - BIOTAS collections, Glorioso, 3-7 May 2009, det. J. Poupin from photo, St. GLOR-4, patch reef, near anchorage, 3-6 m, specimen MEPA 1899. - Mayotte, KUW fieldwork November 2009, St. 23, Choizil pass 'Patate à Teddy' $15-30 \mathrm{~m}, 1$ male $2.68 \times 3.23,1$ female $1.50 \times 1.83 \mathrm{~mm}$, MNHN-Ga7459.

Distribution. - IWP. Red Sea, eastern Africa (Mozambique), Madagascar, Mayotte and Glorioso (first record), Seychelles, Réunion, Australia. Hard bottoms, collected to $110 \mathrm{~m}$.

Remarks. - This species is illustrated in color for the first time. It has affinities with Polyonyx triunguiculatus and its live coloration appears as a good character to recognize it (compare Fig. $11 \mathrm{~A}, \mathrm{C}$ ). Other characters that can be used to separate $P$. biunguiculatus and $P$. triunguiculatus are indicated under $P$. triunguiculatus. Polyonyx biunguiculatus is also very similar, for its live coloration, to P. obesulus Miers, 1884 illustrated in color from Taiwan by Osawa \& Chan (2010: 170, fig. 134). The two are distinguished by dactyls of ambulatory legs, with 2 corneous spines on flexor margin for $P$. biunguiculatus instead of only 1 in $P$. obesulus (see Osawa, 2007a: 31, key). Osawa (2007a: 35 ) indicates that $P$. biunguiculatus is a species complex and has some doubt on record of this species in the Indian Ocean. However based on the characters that he mentions (smooth larger chela and presence of pleopods in male) our specimens confirm the presence of typical P. biunguiculatus in the region.

\section{Polyonyx aff. boucheti Osawa, 2007a}

Polyonyx aff. boucheti (Figure 11 D) - Mayotte, KUW fieldwork November 2009, St. 12, La Prévoyante reef, 6$11 \mathrm{~m}, 1$ ovigerous female 2.20×3.24 mm, MNHN-Ga7465; St. 25, islet M'tzamboro, $15-20 \mathrm{~m}, 1$ ovigerous female $1.90 \times 2.89 \mathrm{~mm}$ (broken), MNHN-Ga7466.

Distribution. - Indian Ocean. Mayotte.

Remarks. - Despite their small size, these two specimens are ovigerous indicating that they are adults. They are similar to Polyonyx boucheti Osawa, 2007a, from Loyalty Islands, 5-40 m, but are distinct by several characters: a) dorsal surface of carapace smooth, without transverse striae; b) front straight, lacking the low median rostral lobe illustrated for $P$. boucheti by Osawa (2007a, fig. $13 \mathrm{~B}$ ); outer face of chelae smooth, without short transverse oblique striae; d) carpus of the cheliped lacking distal tuff of setae. Live coloration of $P$. boucheti is not known but is perhaps distinct as Osawa (2007a) mentions 'Carapace with narrow, transverse and oblique, brown lines' and no patches as illustrated for $P$. aff. boucheti on figure $11 \mathrm{D}$. The specimens from Mayotte are also similar to the Japanese Polyonyx utinomii Miyake, 1943 but are distinct by their smooth carapace (instead of having transverse striae in P. utinomii). Osawa (2001: 513) has reported P. utinomii in the Indian Ocean (Maldives) but, based on location, this record could perhaps belong to $P$. aff. boucheti from Mayotte ${ }^{5}$.

\section{Polyonyx pedalis Nobili, 1905}

Polyonyx pedalis (Figure 11 B) - Mayotte, KUW fieldwork November 2009, St. 19, islet Handrema, north, 6-10 $\mathrm{m}, 1$ female $4.56 \times 4.73 \mathrm{~mm}$, MNHN-Ga7464.

Distribution. - IWP. Red Sea, Mayotte (first record), Indonesia (Kei Islands), New Caledonia. Subtidal to $65 \mathrm{~m}$. Remarks. - Polyonyx pedalis has been redescribed by Osawa (2007b: 26, fig. 3) for comparison with Polyonyx spina Osawa, 2007b, a similar species from Loyalty Islands and Philippines. The two species are remarkable by being the only one among the IWP species to bear spines on posterior (flexor) margin of meri of ambulatory legs (P2-P4). Polyonyx pedalis is distinct from P. spina by sub-parallel lateral margins of the carapace, instead of convex in P. spina. It can be easily distinguished from other Polyonyx from Mayotte by its pilosity, including setae on ventral margin of the chelae, on inner faces of ischia, meri and carpi of chelipeds and ambulatory legs.

${ }^{5}$ When this study was in press, a careful re-examination of the specimens of Polyonyx aff. boucheti from Mayotte, by M. Osawa (October 2012), shows that they can be attributed to Polyonyx boucheti, typical. A separate note is in preparation for that issue (Osawa \& Poupin, 2013 in Marine Biodiversity Records). 


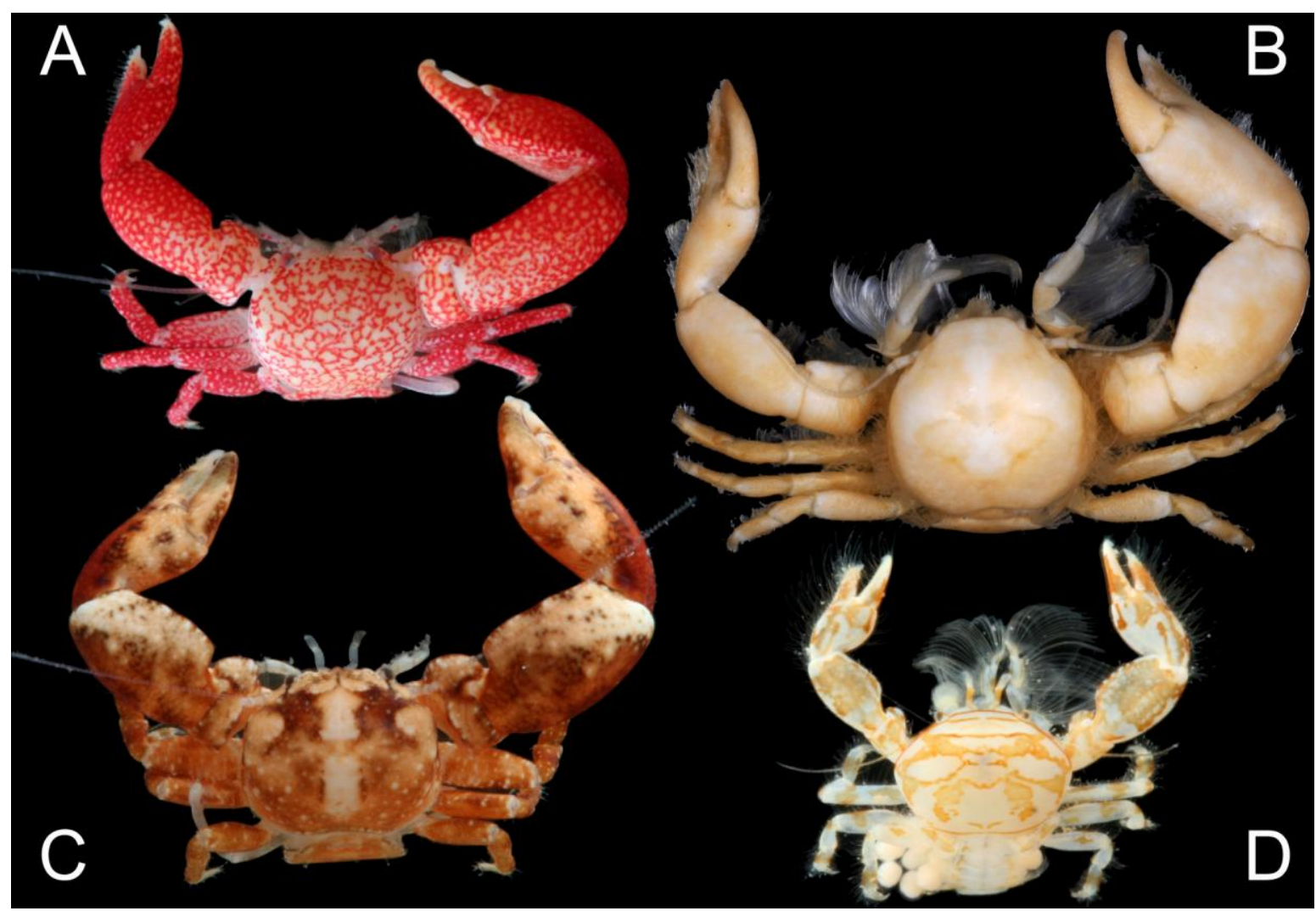

Figure 11. A) Polyonyx biunguiculatus, 1 male $2.68 \times 3.23 \mathrm{~mm}$, Mayotte, St. 23, MNHNGa7459. B) Polyonyx pedalis, 1 female $4.56 \times 4.73 \mathrm{~mm}$, Mayotte, St. 19, MNHN-Ga7464 (coloration altered by preservative). C) Polyonyx triunguiculatus, 1 male $3.69 \times 4.37$, Mayotte, St. 23, MNHN-Ga7438. D) Polyonyx aff. boucheti, 1 ovigerous female $2.20 \times 3.24 \mathrm{~mm}$, Mayotte, St. 12, MNHN-Ga7465.

\section{Polyonyx triunguiculatus Zehntner, 1894}

Polyonyx triunguiculatus (Figure 11 C) - Haig, 1966: 44 (Mayotte, lagoon, small blocks and coarse sands, coll. A. Crosnier, September 1959, 2 males 2.7 and $3.2 \mathrm{~mm}, 1$ female $1.9 \mathrm{~mm}, 2$ ovigerous females 3.1 and $3.2 \mathrm{~mm}$; same, coarse sands, $50 \mathrm{~m}, 1$ male $3.7 \mathrm{~mm}, 1$ female $3.3 \mathrm{~mm}$, MNHN). - BIOTAS collections, Glorioso, 3-7 May 2009 , det. J. Poupin from photo, St. GLOR-2, reef platform and shallow canyons with dead Acropora digitifera head, 7-14 m, specimen MEPA 948; St. GLOR-5, reef slope East side, 17 m, specimen MEPA 1045. - Mayotte, KUW fieldwork November 2009, St. 14, La Prudente bank, 15-17 m, 2 males $3.38 \times 4.13$ and $3.31 \times 3.79$ mm, 1 ovigerous female $3.29 \times 4.20,1$ juvenile broken, MNHN-Ga7436; St. 17, North reef, $22 \mathrm{~m}, 1$ male $3.43 \times 3.94,1$ ovigerous female $3.10 \times 3.97 \mathrm{~mm}$, MNHN-Ga7437; St. 23, Choizil pass 'Patate à Teddy', 15-30 m, 1 male $3.69 \times 4.37,1$ female $2.72 \times 3.12 \mathrm{~mm}, \mathrm{MNHN}-G a 7438$; St. 25, islet M'tzamboro, $15-20 \mathrm{~m}, 1$ ovigerous female $3.46 \times 4.45 \mathrm{~mm}, 1$ female $2.74 \times 3.06 \mathrm{~mm}, 2$ ovigerous females $2.89 \times 3.44$ and $3.40 \times 3.99 \mathrm{~mm}, 1$ female not measured, MNHN-Ga7439; St. 27, islet Mbouzi, 4-20 m, 2 males $4.10 \times 4.76$ and $4.15 \times 4.75$ (one cheliped missing), MNHN-Ga7440; St. 32, islet M'tzamboro, 6-21 m, 1 male 3.40×4.18 mm, MNHN-Ga7441.

Distribution. - IWP. Red Sea, eastern Africa (Tanzania, Zanzibar), Madagascar, Mayotte, Glorioso (first record), Seychelles (Amirante), Réunion, Singapore, western Australia, Indonesia, south China sea, New Caledonia, Loyalty Islands. 
Remarks. - Polyonyx triunguiculatus has affinities with P. biunguiculatus. In complement of distinct live coloration (see Fig. 11 A, C) characters useful to separate them are in Osawa key (2007a: 31). In $P$. biunguiculatus the rostrum is longer, the palm of the chela has a sharp carina on its ventral face, the cutting margins of fingers of chela are furnished with setae (more abundant on the small chela), the dactyl of the ambulatory legs has 2-3 mobile spines on its flexor (ventral) margin (always 2 in P. biunguiculatus). The specific name 'triunguiculatus' is probably based on the presence of 3 mobile spines on the flexor (ventral) margin of the dactyl of ambulatory legs. Although this character is verified for most of the specimens examined, it is not constant and specimens at St. 14 have only 2 mobile spines on that margin.

Based on the numerous specimens collected during the KUW fieldwork a sexual dimorphism of the chelae is observed. In female, the inner face of the palm is rugose or tuberculated; the ventral margin of the chela is carinated and finely denticulated with extension on basal portion of the fixed finger. In the male, the inner face of the palm is smooth and the ventral margin is carinated but not denticulated.

\section{SUPERFAMILY HIPPOIDEA}

The mole crabs have not been sampled during Mayotte KUW fieldwork. For the time being few attention has been paid to this group in Mayotte region. It is represented by a single record in the literature (Fourmanoir, 1955) without additional records retrieved in more recent taxonomic studies consulted for this inventory (Boyko \& Harvey, 1999; Boyko, 2002). Potentially 6 additional species could be found in the region (see in Discussion, Table 1 and Complementary List).

FAMILY HIPPIDAE

\section{Hippa adactyla Fabricius, 1787}

Hippa adactyla - Fourmanoir, 1955: 32 (Grande Comore, Mitsamiouli).

Distribution. - IWP. Eastern Africa (Mozambique, Kenya, Tanzania), Madagascar, Comoros, Seychelles, Mauritius, Australia, Taiwan, Japan, Marquesas.

Remarks. - Color photographs of Hippa adactyla are in Osawa et al. (2010), with a key to Hippa species.

\section{SUPERFAMILY PAGUROIDEA}

\section{FAMILY COENOBITIDAE}

The coenobitids have been already listed, commented and illustrated with the land species presented in Bouchard et al. (2011). Five species are reported in Mayotte region with a key available in Reay \& Haig (1990). The presence of the coconut crab (Birgus latro) is confirmed in Glorioso. Few additional observations are presented here, based on BIOTAS team photographs in May 2009 in Glorioso Islands and also Tromelin Island, a similar coral formation at about $900 \mathrm{~km}$ southeast of the Glorioso. 
Birgus latro (Linnaeus, 1767)

Birgus latro - See Bouchard et al. 2011: 12, fig. 8 A (Glorioso).

\section{Coenobita brevimanus Dana, 1852}

Coenobita brevimanus - See Bouchard et al. 2011: 12, fig. 8 A-B.

\section{Coenobita cavipes Stimpson, 1858}

Coenobita cavipes - See Bouchard et al. 2011: 12, fig. 9 A-B.

\section{Coenobita perlatus H. Milne Edwards, 1837}

Coenobita perlatus (Figure 12 A-C) - See Bouchard et al., 2011: 13, fig. 9 C. - BIOTAS collections, Glorioso, 3-7 May 2009, det. J. Poupin from photo, St. GLOR-12, exposed reef flat, abrasion platform, 1-3 m, specimen MEPA 1261; Tromelin Island, St. TROM-5, coll. M. Malay, 11 May 2009, land, specimen MEPA 1850.

Remarks. - The specimen illustrated from Mayotte in Bouchard et al. (2011: 13, fig. 9C) was a female juvenile almost totally white. Distinct colorations are illustrated here from photographs transmitted by M. Malay: a white-orange intermediate coloration (Fig. 12 A-B), and the typical bright red coloration of an adult (Fig. 12 C).

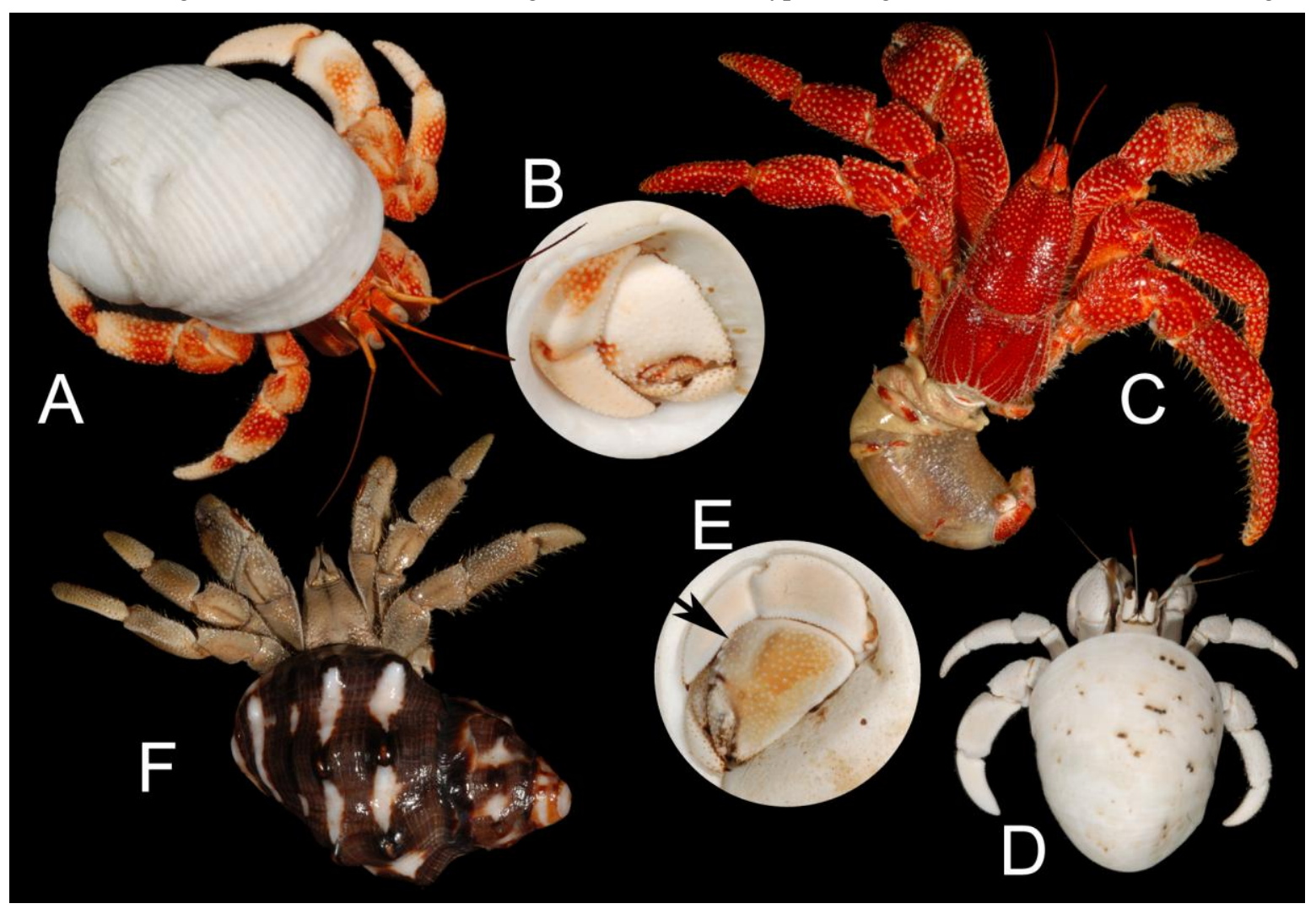

Figure 12. Collection BIOTAS, May 2009, photographs courtesy M. Malay. A-C) Coenobita perlatus. Specimens with intermediate red-orange coloration, Glorioso, MEPA 1261, A) dorsal view, B) aspect of outer face of chela. C) Adult specimen with typical bright red coloration, Tromelin, MEPA 1850. D-F) Coenobita rugosus. D) Juvenile with white coloration, Glorioso MEPA 1262; E) aspect of outer face of chela of another juvenile of about same size, showing brown patch and part of the stridulating apparatus (arrow), Glorioso MEPA 1265; F) adult specimen with brown coloration, Tromelin, MEPA 1853. 


\section{Coenobita rugosus $\mathrm{H}$. Milne Edwards, 1837}

Coenobita rugosus (Figure 12 D-F, 28) - See Bouchard et al., 2011: 14, fig. 9 D-E. - BIOTAS collections, Glorioso, 3-7 May 2009, det. J. Poupin from photo, St. GLOR-12, exposed reef flat, abrasion platform, 1-3 m, specimen MEPA 1262, 1263, 1264, 1265, 1354, 1374; Tromelin Island, St. TROM-5, land, coll. M. Malay, 11 May 2009, specimen MEPA 1853.

Remarks. - These specimens from Glorioso and Tromelin Islands can be identified from photographs to Coenobita rugosus based on: eyestalks strongly compressed; left chela with a stridulating apparatus on upper part of upper surface; and propodus of left P3 with outer surface flattened and marked off from upper surface by a sharp ridge. Coenobita scaevola (Forskål, 1775) is another WIO species with similar characters but it is distinct by the presence of tuft of long setae on mesial face of merus of right cheliped, near ventral margin (absent in C. rugosus). This character was not verified on the photographs examined for this work. However, the geographic distribution of $C$. scaevola is currently limited to Red Sea and African mainland while $C$. rugosus is already known from Mayotte, Madagascar, Seychelles, and probably also, based on these new observations, Glorioso and Tromelin Islands.

The color pattern is variable in this species as illustrated for Taiwanese specimens by McLaughlin et al. (2007). Several juveniles examined here are almost totally white (Fig. $12 \mathrm{D}$ ) but have already a brown patch on the outer face of the larger chela (Fig. 12 E). In the adults this patch is darker with overall color of the body and appendages light brown (Fig. $12 \mathrm{~F}$ ).

\section{FAMILY DIOGENIDAE}

\section{Aniculus maximus Edmonson, 1952}

Aniculus maximus (Figure $13 \mathrm{~A}$ ) - Geyser Bank, between Mayotte and Glorioso, 12²2'S, 46 $33^{\prime} \mathrm{E}$, photograph by V. Dinhut.

Distribution. - IWP. Mayotte (first record), Seychelles, Réunion, Hawaii, French Polynesia. Between 10-100 m. Remarks. - A large-sized Aniculus that can be easily recognized on color photographs, based on its brilliant yellow coloration. It must be widespread in the IWP although it is rarely reported. It is still not known from the eastern African coast, perhaps because it is usually observed at depths of at least $30 \mathrm{~m}$ and deeper.

\section{Aniculus retipes Lewinsohn, 1982}

Aniculus retipes (Figure 13 B) - BIOTAS collections, Glorioso, 3-7 May 2009, det. J. Poupin from photo, St. GLOR-4, patch reef, near anchorage, 3-6 m, specimen MEPA 1957; St. GLOR-7, reef slope West side, 5-20 m, specimen MEPA 1225.

Distribution. - IWP. Red Sea, eastern Africa (Tanzania), Glorioso (first record), Christmas Island, Cocos Keeling, Indonesia, Vietnam, Taiwan, Japan, eastern Australia, ?Solomon, Wallis \& Futuna, Samoa, French Polynesia.

Remarks. - A medium to large-sized Aniculus. It is recorded for the first time in Mayotte region based on its coloration, as illustrated on figure $13 \mathrm{~B}$.

\section{Aniculus ursus (Olivier, 1811)}

Aniculus aniculus - Fourmanoir, 1955: 28 (Anjouan: Domoni), not Aniculus aniculus (Fabricius, 1787) known with certainty from Pacific only (see Remarks). - Aniculus ursus (Figure 13 C) - Forest, 1984: 26 (Genus revision).

Distribution. - Widespread in the IWP. Eastern Africa (Mozambique), Madagascar, Comoros, Seychelles, Réunion, Mauritius, Rodriguez, Christmas, Maldives, Cocos-Keeling, Australia, Indonesia (Sulawesi), China sea (Xisha), Taiwan, Japan, Caroline, Marianas, Marshall, New Caledonia, Loyalty, Fiji, Wallis \& Futuna, Samoa.

Remarks. - In Forest (1984) revision of the genus Aniculus, all records of A. aniculus from the Indian Ocean are corrected into A. ursus. Although Fourmanoir (1955) A. aniculus record is not cited explicitly by Forest, it must 
also belongs to A. ursus. This species is widespread in the IWP but its geographical extension to the east seems limited to Wallis \& Futuna and Samoa in the South Pacific. On the opposite, A. aniculus seems to be confined in the Pacific, reported only from Ogasawara Islands, Johnston atoll, Cook Islands and French Polynesia.
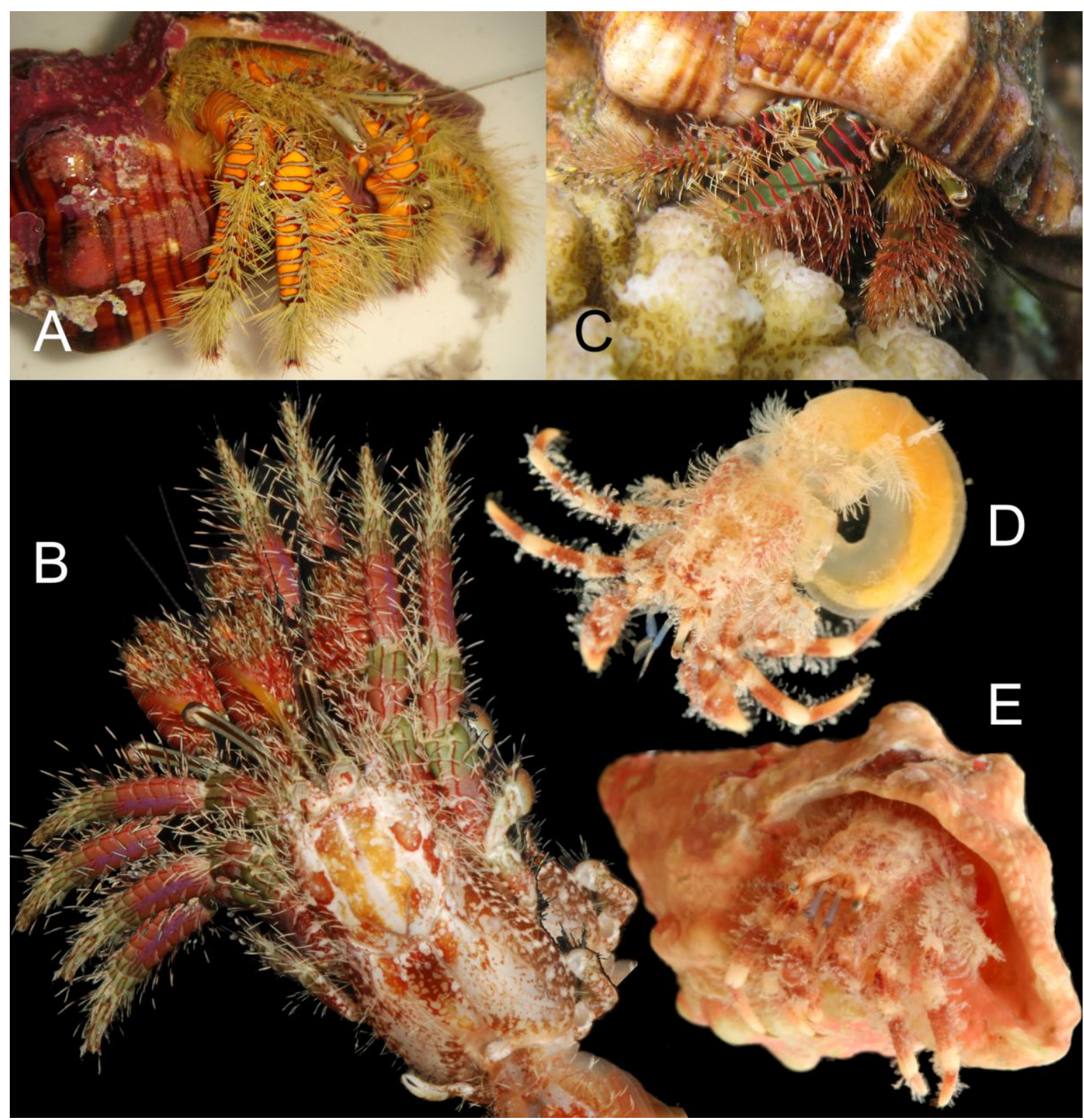

Figure 13. A) Aniculus maximus, specimen from Geyser Bank (photo V. Dinhut). B) Aniculus retipes, specimen from Glorioso, MEPA 1957 (photo BIOTAS team, courtesy M. Malay). C) Aniculus ursus, specimen from Réunion Island (photo S. Ribes). D-E) Areopaguristes abbreviatus, 1 male Lc $2.1 \mathrm{~mm}$, Lt about 18 mm, Mayotte, St. 32, MNHN-Pg8512. 


\section{Areopaguristes abbreviatus (Dechancé, 1963)}

Areopaguristes abbreviatus (Figure 13 D-E) - BIOTAS collections, Glorioso, 3-7 May 2009, det. J. Poupin from photo, St. GLOR-14, fore reef platform, 13-14.5 m, specimen MEPA 1498, 1517, 1518; St. GLOR-18, fore reef platform, specimen MEPA 1530, 1547, 1550. - Mayotte, KUW fieldwork November 2009, St. 19, islet Handrema, 6-10 m, 1 female S1 2.7 mm, MNHN-Pg8508; St. 21b, islet Choizil, 15-20 m, 1 ovigerous female S1 $1.9 \mathrm{~mm}$ (with larvae), MNHN-Pg8509; St. 23, Choizil pass, 1 male Sl $1.8 \mathrm{~mm}, 1$ female Sl $2.3 \mathrm{~mm}$ (plus 1 juvenile from St. 14 in the same tube), MNHN-Pg8510; St. 25, islet M'tzamboro, 15-20 m, 1 ovigerous female S1 $2.0 \mathrm{~mm}$, Lt about $9.8 \mathrm{~mm}, 1 \mathrm{male}$ S1 $1.4 \mathrm{~mm}$, Lt about $7.9 \mathrm{~mm}$, with a 'worm' in the shell, MNHN-Pg8511; St. 32, islet M'tzamboro, 6-21 m, 1 specimen in its shell, 1 male S1 $2.1 \mathrm{~mm}$, Lt about $18 \mathrm{~mm}$, as 'Clibanarius sp. St. 32' in Bouchard et al., 2009: photo p. 96, MNHN-Pg8512. - Rahayu \& McLaughlin, 2010 : 67 (generic replacement name for Stratiotes).

Distribution. - WIO. Persian Gulf, eastern Africa (Kenya), Madagascar, Mayotte and Glorioso (first record).

Remarks. - Areopaguristes abbreviatus has been already reported in the vicinity of Mayotte region, at Madagascar (Dechancé 1963, 1964; under Paguristes). A redescription of the species is also provided by Rahayu (2007, under Stratiotes abbreviatus). Dechancé (1963) indicates that Paguristes abbreviatus has affinities with Paguristes jousseaumei Bouvier, 1892, from the Red Sea, and Paguristes perspicax Nobili, 1906 (now in Areopaguristes), from Red Sea and Persian Gulf. The three species are remarkable by the presence of a single female genital opening on P3 coxa. Dechancé (1963) has used the variation of pilosity to separate the three species. This character varies according to sex on the specimens observed for this study (setae soft in males but stiff in females) but overall it is confirmed here that the pilosity is more furnished in A. abbreviatus than in the $P$. jousseaumei specimens examined for comparison in MNHN collections.

\section{Areopaguristes micheleae (Rahayu, 2005)}

Stratiotes micheleae - Rahayu, 2007: 528 (Mozambique channel, BENTHEDI Expedition, St. DR 38, Mayotte, east of Bandrélé reef, 12 ${ }^{\circ} 54.8^{\prime} \mathrm{S}, 4^{\circ} 15.6$ 'E, 200-500 m, 26 March 1977, 1 female Sl 2.4 mm, MNHN). Areopaguristes micheleae - Rahayu \& McLaughlin, 2010: 67 (replacement name for genus Stratiotes).

Distribution. - Indonesia, Madagascar, and Mayotte region, 200 to $605 \mathrm{~m}$.

\section{Calcinus laevimanus (Randall, 1840)}

Calcinus laevimanus (Figure 14 A-B) - Fourmanoir, 1955: 28 (Comoros; 'Espèce très abondante'). - BIOTAS collections, Glorioso, 3-7 May 2009, det. J. Poupin from photo, St. GLOR-12, exposed reef flat, abrasion platform, 1-3 m, specimen MEPA 1281, 1323; St. GLOR-14, fore reef platform, 13-14.5 m, specimen MEPA 1422; St. GLOR-16, reef flat all along coast of Grande Glorieuse, 0-3 m, specimen MEPA 1445. - Mayotte, KUW fieldwork November 2009, St. 1, Trévani Beach, intertidal, 1 female S1 3.9 mm, 4 specimens in their shells, MNHN-Pg8458; St. 2, Trévani to Kangani mangrove, intertidal, 8 specimens in their shells, MNHNPg8459; St. 6, Badamiers spillway, intertidal, 2 adults, 9 juveniles in their shells, MNHN-Pg8460; St. 19 et 20a, islets Handrema and M'tzamboro, intertidal, field notes only, no samples; St. 26, Mutsumbatsou reef flat, intertidal, 2 ovigerous females S1 2.8 and 4.2 mm, MNHN-Pg8461; St. 31, 3 males Sl 4.7-4.9 mm, MNHNPg8462.

Distribution. - Widespread in the IWP. Eastern Africa, Comoros, Mayotte, Glorioso, Seychelles, Réunion, Mauritius, Rodriguez, Cocos and Christmas, Indonesia, Australia, Taiwan, Japan, Marianas, New Caledonia, Wallis \& Futuna, Cook, French Polynesia, Hawaii.

Remarks. - One of the most common Calcinus in intertidal and shallow subtidal zone of Mayotte (Fig. 14 A). It is easily identifiable by its coloration (see Fig. 14 B) and by smooth aspect of upper margin of its small chela (right). In all others Calcinus species of Mayotte region this upper margin has spines. 


\section{Calcinus latens (Randall, 1840)}

Calcinus latens (Figure 14 C-D) - Coll. Anker \& Michonneau, 2008, St. MAY08-St1, Mboianatsa reef, UF 14969; St. MAY08-St5/6, S pass, on sand bottom, UF16560. - BIOTAS collections, Glorioso, 3-7 May 2009, det. J. Poupin from photo, St. GLOR-12, exposed reef flat, abrasion platform, 1-3 m, specimen MEPA 1250, 1282, 1324. - Mayotte, KUW fieldwork November 2009, St. 5, Great north east reef, $1 \mathrm{~m}, 1 \mathrm{male}$ S1 $5.7 \mathrm{~mm}$, Lc $10.7 \mathrm{~mm}$, Lt about $28 \mathrm{~mm}$, MNHN-Pg8463; St. 6, Badamiers spillway, intertidal, 2 males Sl 3.5 and $3.5 \mathrm{~mm}, 1$ specimen in shell, MNHN-Pg8464; St. 8, Great north-eastern reef, 6-8 m, 2 males S1 2.9 and 3.1 m, MNHNPg8465, 8 males S1 2.2-5.2 mm, MNHN-Pg8466; St. 12 'La Prévoyante' reef, 6-12 m and St. 15, islet Mtsamboro, 0-3 m, field notes only, no samples; St. 20a, islet M'tzamboro, intertidal, 1 ovigerous female S1 2.2 mm, 1 female $2.2 \mathrm{~mm}$, MNHN-Pg8507; St. 26, Mutsumbatsou reef flat, intertidal, 2 males S1 3.2 and $3.9 \mathrm{~mm}$, MNHN-Pg8467.

Distribution. - Widespread in the IWP. Persian Gulf, Eastern Africa, Madagascar, Mayotte, Glorioso, Seychelles, Réunion, Mauritius, Cocos and Christmas, Australia, Indonesia, Thailand, Taiwan, Japan, New Guinea, New Caledonia, Loyalty, Lord Howe, Norfolk, Wallis \& Futuna, French Polynesia. In coral rubbles, sometimes in coral branches (e.g. Pocillopora), intertidal to subtidal.

Remarks. - Very common in intertidal and shallow subtidal zone of Mayotte. This species can be identified by the dark-red ring at base of dactyls of ambulatory legs (see Fig. 14 C-D). Calcinus latens as accepted nowadays is a complex of species. Specimens from Mayotte region belong to the typical IWP form whereas populations of Oman and Hawaii are slightly different (see Malay \& Paulay, 2009) and will probably be separated as distinct species in the future.

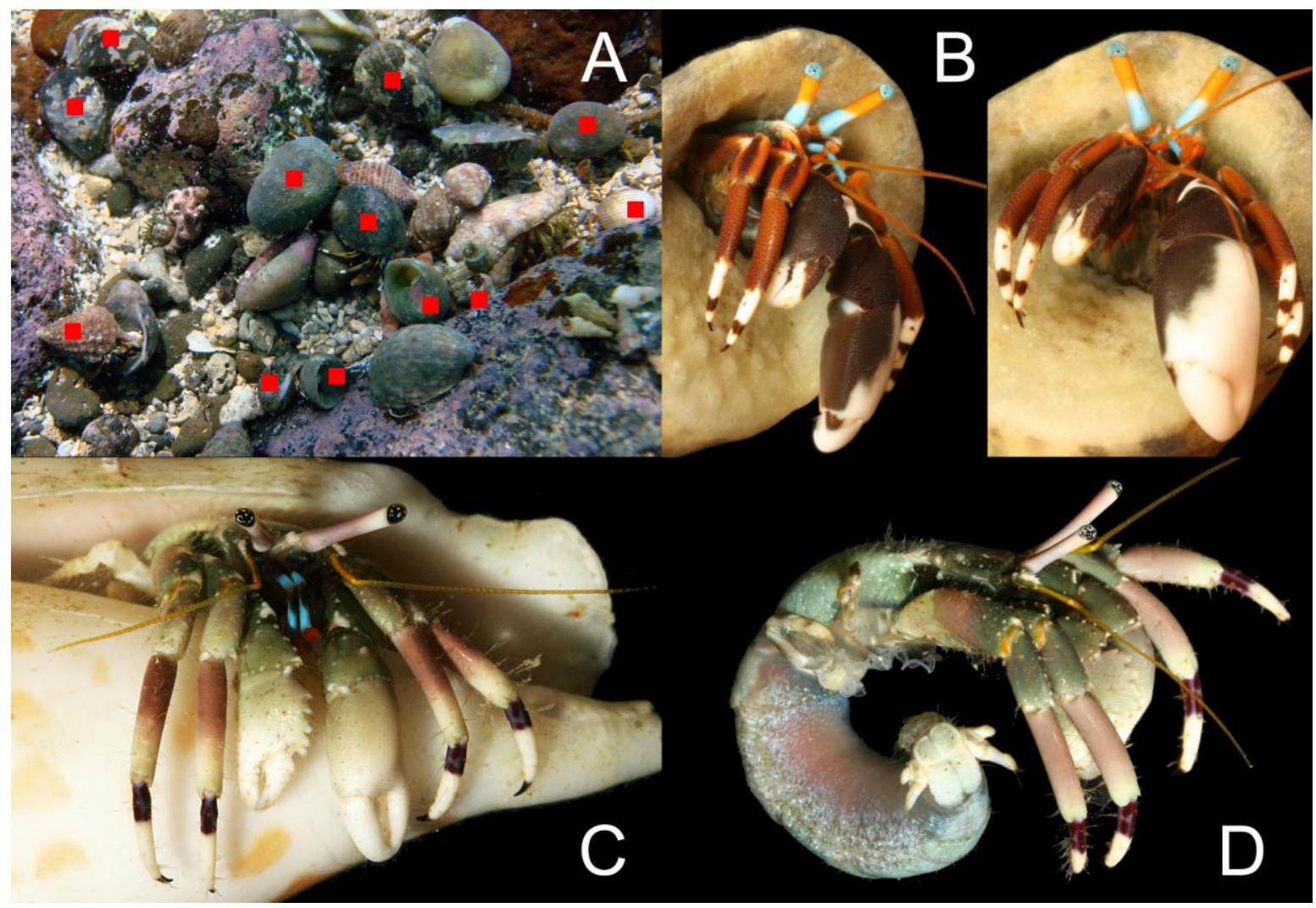

Figure 14. A-B) Calcinus laevimanus. A) Colony at Mayotte, St. 20, depth about $0.5 \mathrm{~m}$, each red square identify a shell occupied by an hermit crab C. laevimanus; B) 1 male S1 about 4.9 $\mathrm{mm}$, in its shell, lateral and frontal view, Mayotte, St. 31, MNHN-Pg8462. C-D) Calcinus latens. C) 1 male S1 $3.1 \mathrm{~mm}$, in its shell, frontal view, Mayotte, St. 8, MNHN-Pg8465; D) 1 male S1 5.7 mm, Lt about 28 mm, lateral view, Mayotte, St. 5, MNHN-Pg8463. 


\section{Calcinus morgani Rahayu \& Forest, 1999}

Calcinus gaimardii - Fourmanoir, 1955: 29 (Comoros, Mohéli, Numa Choa; ?not C. gaimardii (H. Milne Edwards, 1848); due to indication that ocular peduncles are blue distally, this is probably C. morgani rather than C. gaimardii; see Remarks). - Calcinus morgani - Geyser Bank, between Mayotte and Glorioso, $12^{\circ} 22 ' \mathrm{~S}$, 463'E, photograph V. Dinhut. - Coll. Anker \& Michonneau, 2008, St. MAY08-St2, Mayotte, Tanaraki reef, UF 13718. - BIOTAS collections, Glorioso, 3-7 May 2009, det. J. Poupin from photo, St. GLOR-4, patch reef, near anchorage, 3-6 m, specimen MEPA 1950; St. GLOR-12, exposed reef flat, abrasion platform, 1-3 m, specimens MEPA 1270, 1275, 1280 (Figure 15 A).

Distribution. - IWP. Eastern Africa (South Africa, Somalia), Madagascar, Comoros, Mayotte, Glorioso, Seychelles, Réunion, Indonesia, Australia, Malaysia, Vietnam, Taiwan, Japan, Marianas, Papua New Guinea, Vanuatu, Wallis \& Futuna, French Polynesia. Intertidal and shallow subtidal zone.

Remarks. - Before its description by Rahayu \& Forest (1999) Calcinus morgani was confused with $C$. gaimardii (H. Milne Edwards, 1848). These species are similar for dark brown color of chelipeds and ambulatory legs but can be easily separated by distinct coloration of their ocular peduncles, as illustrated on figure 15 B-C. Presence of $C$. morgani is confirmed here for Mayotte region based on A. Anker determination and color photographs examined from Geyser bank (V. Dinhut) and Glorioso (BIOTAS team). Presence of Calcinus morgani is also confirmed here for the Seychelles (Silhouette Island), based on a color photograph transmitted by P. Hogarth to the first author (20 August 2007). Calcinus gaimardii is known with certainty from the Pacific only.

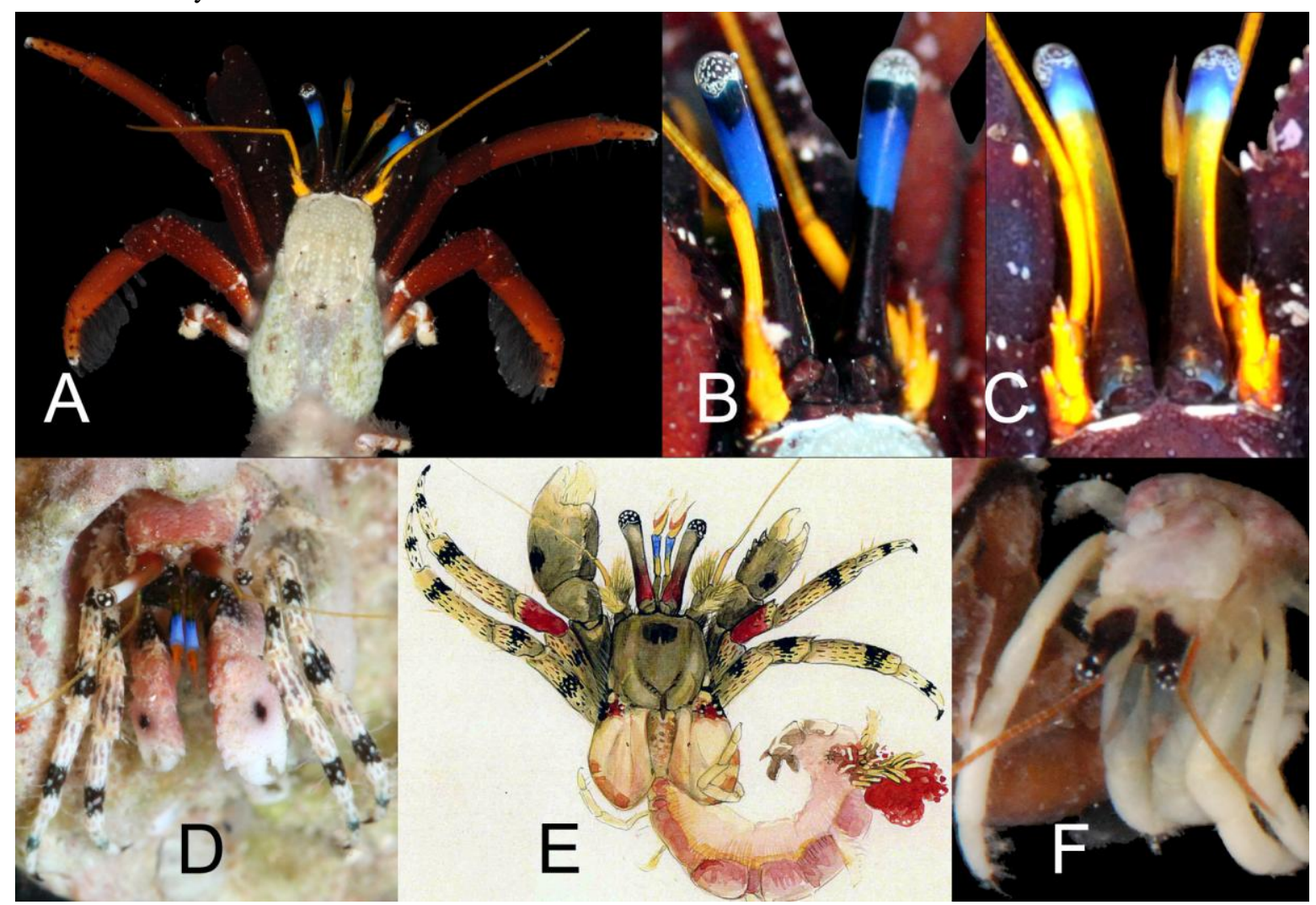

Figure 15. A-B) Calcinus morgani. A) Glorioso, specimen MEPA 1280 (photo BIOTAS team, courtesy M. Malay); B) Detail of coloration of ocular peduncles, specimen from Moorea. C) Calcinus gaimardii, detail of coloration of ocular peduncle, specimen from New Caledonia. D) Calcinus aff. pulcher, Mayotte, 1 specimen S1 3.8 mm, St. 20b, MNHN-Pg8468. E) Calcinus pulcher, Cauda Bay, Nhatrang, Vietnam, type locality, 'red-knee' typical form with carpus of P2 in brilliant red (watercolor from R. Serène archives, artist ' $\mathrm{M}^{\mathrm{r}}$ Vam', 24 May 1954). F) Calcinus aff. vachoni, Glorioso, specimen MEPA 925 (photo BIOTAS team, courtesy M. Malay). 


\section{Calcinus aff. pulcher Forest, 1958}

Calcinus aff. pulcher (Figure 15 D) - BIOTAS collections, Glorioso, 3-7 May 2009, det. J. Poupin from photo, St. GLOR-2, reef platform and shallow canyons with dead Acropora digitifera head, 7-14 m, specimen MEPA 921, 929; St. GLOR-10, near military base, reef slope, 15-20 m, specimen MEPA 1216. - Mayotte, KUW fieldwork November 2009, St. 20b, islet M'tzamboro, 10-15 m, , as 'Calcinus pulcher St. 14 (sic)' in Bouchard et al., 2009: photo p. 99, 1 specimen in its shell, Sl $3.8 \mathrm{~mm}$, MNHN-Pg8468; St. 23, Choizil pass, 15-30 m, 1 ovigerous female S1 $2.3 \mathrm{~mm}$, Lt about $14 \mathrm{~mm}$, MNHN-Pg8469.

Distribution. - Calcinus pulcher sensu lato (including $C$. aff. pulcher of this study) is an IWP species reported in Mayotte region, Seychelles, Réunion, Cocos-Keeling, Vietnam, Taiwan, Indonesia, Japan, Palau, New Caledonia and Loyalty Islands. However, based on color pattern (compare Fig. 15 D-E) and DNA sequences ( $c f$. Malay \& Paulay, 2009) there is a distinct population of $C$. pulcher in the WIO, including the present records for Mayotte region and also the record from Réunion Island by Poupin (2009).

Remarks. - Free or living in coral branches, subtidal to about 30-40 m.

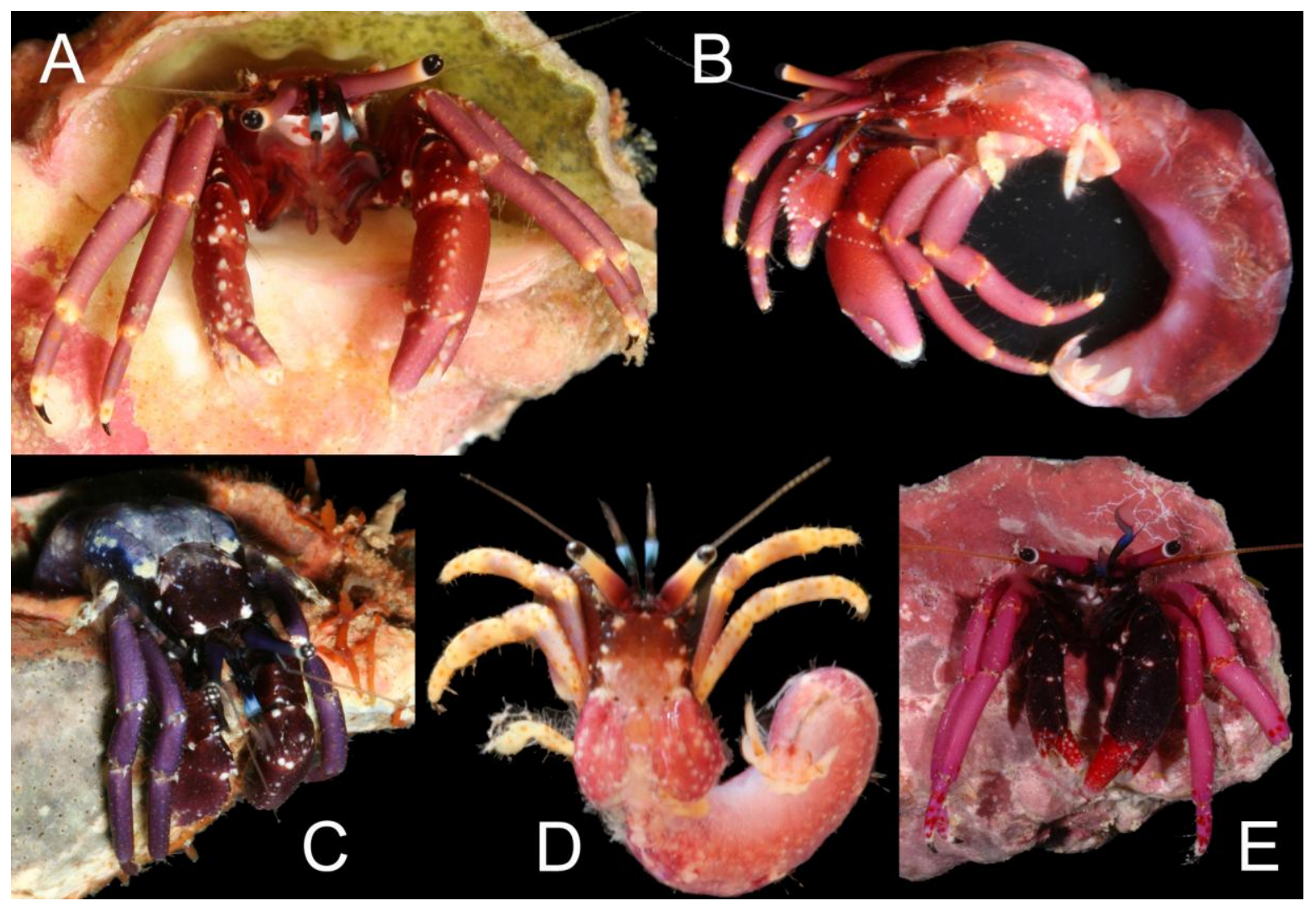

Figure 16. A-D) Calcinus rosaceus, Mayotte. A) frontal view, specimen alive in its shell, St. 23, MNHN-Pg8475; B) 1 male S1 4.5 mm, lateral view, St. 14, MNHN-Pg8474; C) 1 male with deep violet coloration, S1 $3.1 \mathrm{~mm}$, Lc $6.0 \mathrm{~mm}$, St. 3, MNHN-Pg8470; D) 1 juvenile with distinct color pattern, Sl 1.5 mm, St. 14, MNHN-Pg8474. E) Calcinus haigae, specimen from Moorea, French Polynesia (photo G. Paulay). 


\section{Calcinus rosaceus Heller, 1861}

Calcinus rosaceus (Figure 16 A-D) - BIOTAS collections, Glorioso, 3-7 May 2009, det. J. Poupin from photo, St. GLOR-2, reef platform and shallow canyons with dead Acropora digitifera head, 7-14 m, specimen MEPA 923, 924, 928, 942, 1936; St. GLOR-4, patch reef, near anchorage, 3-6 m, specimen MEPA 1938; St. GLOR-5, reef slope East side, $17 \mathrm{~m}$, specimen MEPA 1230; St. GLOR-10, near military base, reef slope, 15-20 m, specimens MEPA 1212, 1213, 1217, 1218; St. GLOR-14, fore reef platform, 13-14.5 m, specimen MEPA 1495, 1499, 1515; St. GLOR-19, fore reef platform and dead small Pocillopora, 13-14 m, specimen MEPA 1622. Mayotte, KUW fieldwork November 2009, St. 3, Trévani fringing reef, 1-8 m, 1 male Sl $3.1 \mathrm{~mm}$, Lc $6.0 \mathrm{~mm}$, MNHN-Pg8470; St. 4, 'La Prévoyante' reef, 6-10 m, 1 female Sl 5.1 mm, Lt about 29 mm, MNHN-Pg8471; St. 8, Great north-eastern reef, 6-8 m, 1 male Sl 4.3 mm, MNHN-Pg8472; St. 12, 'La Prévoyante' reef, 6-12 m, 1 ovigerous female Sl 2.7 mm, Lc $4.2 \mathrm{~mm}, 4$ specimens in shells, MNHN-Pg8473; St. 14, 'La Prudente' bank, $15-17 \mathrm{~m}$, as 'Clibanarius aff. spicatus St. 14' in Bouchard et al., 2009: photos p. 99, 1 male Sl 4.5 mm, 1 juvenile Sl about $1.5 \mathrm{~mm}, 3$ males Sl 4.2-4.6 mm, 1 female Sl $3.3 \mathrm{~mm}, 4$ juveniles, MNHN-Pg8474; St. 20a, islet M'tzamboro, 0-1 m, 1 male Sl 2.5 mm, MNHN-Pg8505; St. 21b, islet Choizil, 15-20 m, 1 specimen in shell (collected with Pylopaguropsis and Areopaguristes), MNHN-Pg8506; St. 23, Choizil pass 'Patate à Teddy', 15$30 \mathrm{~m}, 2$ males Sl 3.2-3.8 mm, 2 ovigerous females Sl 3.8 and $4.2 \mathrm{~mm}, 4$ specimens in shells, MNHN-Pg8475; St. 25, islet M'tzamboro, 15-20 m, 7 specimens in shells, MNHN-Pg8476; St. 30, Rani reef, 3-15 m, 1 juvenile, with coloration distinct from adults, MNHN-Pg8504; St. 32, islet M'tzamboro, 6-21 m, 1 male S1 $3.2 \mathrm{~mm}, 1$ specimen in shell, MNHN-Pg8477.

Distribution. - WIO. Red Sea, Gulf of Aqaba, Gulf of Aden, Mayotte and Glorioso (first record), Réunion, Mauritius.

Remarks. - In Calcinus the aspect of the terminal margin of the ocular scale is an important specific character, with two states: 1) a single terminal spine, and 2) several terminal spines. Although Calcinus rosaceus belongs to state 2 it has been observed that an ovigerous female at St. 4 has a single terminal spine on its ocular scale. This kind of variation can lead to misidentification when using traditional keys, such as in Poupin \& McLaughlin (1998).

Calcinus rosaceus has affinities with Calcinus haigae Wooster, 1984 which is known with certainty from the Pacific Ocean (see Malay \& Paulay, 2009, fig. 5). Calcinus haigae is reported in the Indian Ocean by Gherardi \& McLaughlin (1994; Mauritius), Hogarth et al. (1998; Maldives) and McLaughlin \& Hogarth (1998; Seychelles). According to McLaughlin \& Hogarth (1998: 6) these records (at least Mauritius) are based on the fact that the color pattern of $\mathrm{P} 2 / \mathrm{P} 3$ is 'not uniform'. However, observations made for this study show that color of $C$. rosaceus can varies for the adults (Fig. 16 A-C) and juveniles (Fig. 16 D). In juveniles color variation includes spots on P2/P3, a pattern also observed in juveniles of C. morgani from Japan (Komai, 2004). Therefore, in the Indian Ocean, previous records of $C$. haigae with color pattern of P3 'not uniform' are potentially based on juveniles of $C$. rosaceus. Although the presence of $C$. haigae in the Indian Ocean cannot be excluded, it should be confirmed by observation of typical adult color pattern, with pink spots at tip of P2/P3 (see Fig. 16 E), and/or by DNA sequences as Malay \& Paulay (2009: 650, fig. 5) show that they are useful to distinguish C. haigae and C. rosaceus. 


\section{Calcinus aff. vachoni Forest, 1958}

Calcinus aff. vachoni (Figure 15 F) - BIOTAS collections, Glorioso, 3-7 May 2009, det. J. Poupin from photo, St. GLOR-2, reef platform and shallow canyons with dead Acropora digitifera head, 7-14 m, specimen MEPA 925. - Mayotte, KUW fieldwork November 2009, St. 23, Choizil pass 'Patate à Teddy', 15-30 m, 1 male Lc 1.4 $\mathrm{mm}$, MNHN-Pg8478.

Distribution. - IWP for Calcinus vachoni sensu lato (including C. aff. vachoni of this study). Mayotte, Glorioso, Réunion, Mauritius, western Australia, Taiwan, Japan, Micronesia, French Polynesia, Easter Island. Malay \& Paulay (2009) have recognized a cryptic population of C. vachoni in the Mascarene. Specimens reported here as $C$. aff. vachoni belong to this population as are the specimen illustrated from Réunion by Poupin (2009: 67) and probably also previous records of $C$. vachoni from Mauritius.

Remarks. - The small specimen of $C$. aff. vachoni collected during the KUW fieldwork was mixed with a lot of others pagurids. It is identified based on few remains of color, including: black patches on the ocular peduncles; dark blue distal segment of antennular peduncles; orange distal segment of antennae. Additionally, the distal pilosity of P3 is more furnished than on distal P2 but without making a brush of setae, as observed in typical $C$. vachoni.

\section{Ciliopagurus tricolor Forest, 1995}

Ciliopagurus tricolor (Figures 3 D, 17 A) - Geyser Bank, between Mayotte and Glorioso, $12^{\circ} 22^{\prime} \mathrm{S}, 46^{\circ} 33^{\prime} \mathrm{E}$, from photograph by V. Dinhut. - Coll. Anker \& Michonneau, 2008, St. MAY08-St1, Mboianatsa reef, UF 14968; St. MAY08-St5/6, S pass, UF15297. - BIOTAS collections, Glorioso, 3-7 May 2009, det. J. Poupin from photo, St. GLOR-12, exposed reef flat, abrasion platform, 1-3 m, specimen MEPA 1279. - Mayotte, KUW fieldwork November 2009, St. 5, seagrass bed and coral rubbles, $1 \mathrm{~m}, 1$ male Sl $3.9 \mathrm{~mm}$, in its shell, 1 male S1 $5.1 \mathrm{~mm}, 1$ female Sl $5.0 \mathrm{~mm}, 1$ juvenile in its shell, MNHN-Pg8541; St. 26, Mutsumbatsou reef flat, intertidal, 1 male S1 5.7 mm, MNHN-Pg8542; St. 28, islet Mbouini, 3-20 m, 1 specimen in cone shell Sl 3.5 mm, MNHNPg8543.

Distribution. - WIO. Eastern Africa (Somalia, Kenya, Tanzania, Zanzibar, Mozambique), Europa, Madagascar, Mayotte and Glorioso (first record), Réunion. Perhaps also ?Chagos. Intertital to 5-30 m.

Remarks. - This beautiful hermit crab is easily recognizable by its orange chelae and legs banded with composite colored rings (median pale blue ring flanked by two bright red rings). This color pattern is used by Poupin \& Malay (2009) to separate C. tricolor, probably endemic to WIO, from sibling species in the Pacific (e.g. C. vakovako Poupin, 2001; C. galzini Poupin \& Malay, 2009).

\section{Clibanarius englaucus Ball \& Haig, 1972}

Clibanarius englaucus (Figure 17 B-D) - BIOTAS collections, Glorioso, 3-7 May 2009, det. J. Poupin from photo, St. GLOR-13, in front of Military camp, 'Îlot aux crabes', intertidal, specimen MEPA 1351. - Mayotte, KUW fieldwork November 2009, St. 2, from Trévani to Kangani Mangrove, intertidal, 9 specimens in their shells, MNHN-Pg8479; St. 6, Badamiers spillway, intertidal, 1 male S1 $1.9 \mathrm{~mm}$, Lt about $13 \mathrm{~mm}, 1$ female Sl $1.2 \mathrm{~mm}$, Lt about $6.4 \mathrm{~mm}, 1$ ovigerous female Sl $1.8 \mathrm{~mm}, 5$ additional small specimens in shells, MNHNPg8481; St. 29, Mboianatsa beach, intertidal, as 'Clibanarius cf. virescens St. 29' in Bouchard et al., 2009: photos p. 95, 1 male Sl $3.1 \mathrm{~mm}$, Lt about $17 \mathrm{~mm}$, MNHN-Pg8480.

Distribution. - IWP. Mayotte and Glorioso (first record), Indonesia, Taiwan, Japan, Papua New Guinea. This is the first record of the species in the Indian Ocean.

Remarks. - A small-sized hermit crab. A small female $(\mathrm{Sl} 1.2 \mathrm{~mm})$ is already ovigerous. The species was collected in the intertidal and subtidal, with Clibanarius virescens. The coloration, illustrated on figure $17 \mathrm{~B}-\mathrm{C}$, overall corresponds to that described by Haig \& Ball (1988) and to color illustrations given for Taiwanese specimens by Yu \& Foo (1991, under 'Clibanarius humilis') and McLaughlin et al. (2007: 123). On Mayotte specimens the color pattern varies somewhat with size as illustrated on figure $17 \mathrm{D}$ for a male juvenile S1 1.9 $\mathrm{mm}$ (blue tints present on propodi of ambulatory legs). Clibanarius englaucus has affinities with Clibanarius merguiensis De Man, 1888 already reported in the area (Kenya, Madagascar, Mauritius). McLaughlin et al. 
(2007: 123, 133) have illustrated both species in color. Although coloration have some resemblances in both species, the longitudinal dorso-mesial stripe on ocular peduncles is brown in $C$. englaucus instead of blue in $C$. merguiensis, and the carpi and propodi of $\mathrm{P} 3$ are dark brown in adults of $C$. englaucus instead of having brown, orange and bluish tints in C. merguiensis.

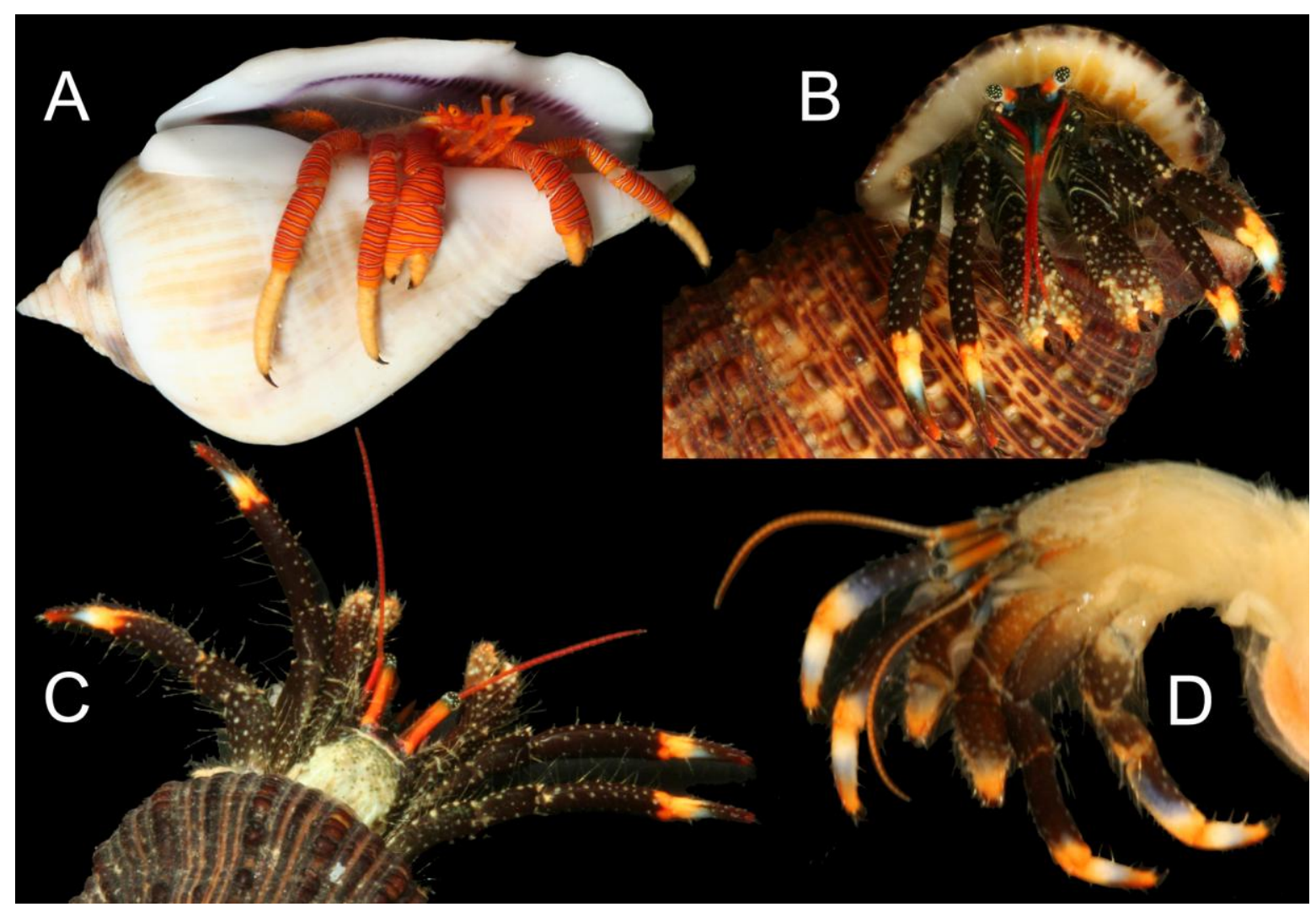

Figure 17. A) Ciliopagurus tricolor. 1 male S1 $3.9 \mathrm{~mm}$ in its shell, Mayotte, St. 5, MNHNPg8541. B-D) Clibanarius englaucus. 1 male in its shell Sl $3.1 \mathrm{~mm}$, Lt about $17 \mathrm{~mm}$, Mayotte, St. 29, MNHN-Pg8480, B) frontal view, C) dorsal view; D) variation of P2-P3 coloration (slightly altered by preservative) in a male juvenile S1 $1.9 \mathrm{~mm}$, Mayotte, St. 6, MNHN-Pg8481.

\section{Clibanarius eurysternus Hilgendorf, 1878}

Clibanarius eurysternus (Figure 18 A) - BIOTAS collections, Glorioso, 3-7 May 2009, det. J. Poupin from photo, St. GLOR-12, exposed reef flat, abrasion platform, 1-3 m, specimen MEPA 1278. - Mayotte, KUW fieldwork November 2009, St. 10, islet Quatre Frères, intertidal, 1 male Sl 3.9 mm, Lt about $35 \mathrm{~mm}$, MNHNPg8482, 3 males S1 3.8-5.0 mm, 3 ovigerous females, S1 3.4-3.9 mm, MNHN-Pg8483, 6 specimens in their shells, MNHN-Pg8484; St. 26, Mutsumbatsou reef flat, intertidal, 2 males Sl 3.8 and $4.6 \mathrm{~mm}, 1$ ovigerous female S1 3.3 mm, MNHN-Pg8485; St. 26b, coll. V. Dinhut, 1 male Sl $5.0 \mathrm{~mm}$, Lt about $43 \mathrm{~mm}$, MNHNPg8486; St. 29, Mboianatsa beach, intertidal, 1 specimen in its shell, MNHN-Pg8487; St. 38, Chiconi/Sada bay, intertidal, coll. J.-M. Bouchard and V. Dinhut, 1 female S1 3.6 mm, Lt about 26 mm, MNHN-Pg8488.

Distribution. - IWP. Eastern Africa (Somalia, Kenya, Mozambique), Madagascar, Mayotte and Glorioso (first record), Singapore, Vietnam, Taiwan, Japan, Philippines, Australia, Wallis \& Futuna, French Polynesia.

Remarks. - A medium-sized species easily identifiable by its color pattern as illustrated on figure 18 A. Although it is rather common in the intertidal this is apparently the first record for Mayotte. 


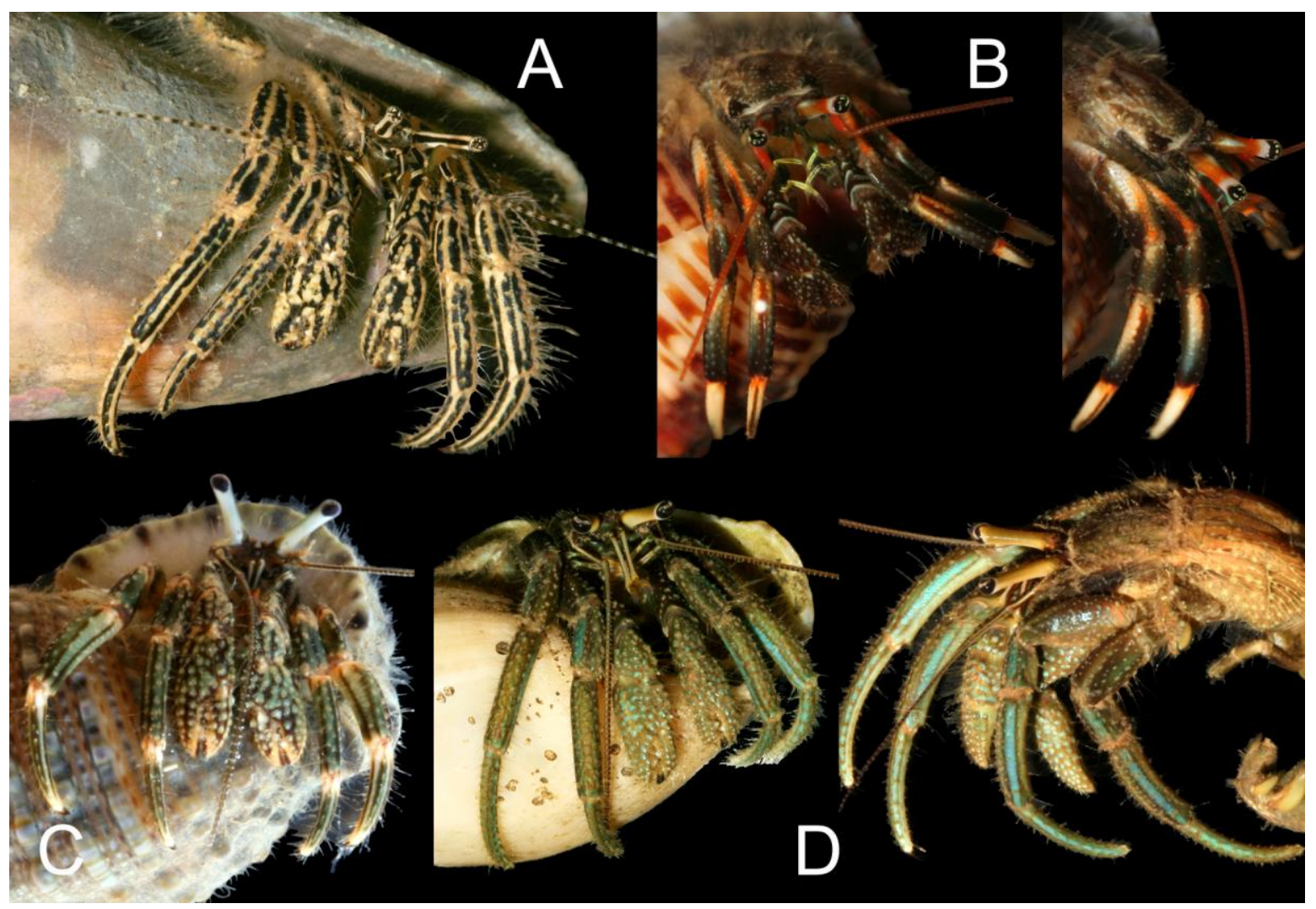

Figure 18. A) Clibanarius eurysternus. 1 male Sl $3.9 \mathrm{~mm}$, Lt about $35 \mathrm{~mm}$, Mayotte, St. 10, MNHN-Pg8482. B) Clibanarius humilis. 1 specimen alive in its shell, frontal and lateral view, Mayotte, St. 10, MNHN-Pg8489. C) Clibanarius laevimanus. 1 specimen alive in its shell, Mayotte, St. 1, MNHN-Pg8490. D) Clibanarius longitarsus. 1 male S1 5.7 mm, Lt about 34 $\mathrm{mm}$, frontal and lateral view, Mayotte, St. 2, MNHN-Pg8495.

\section{Clibanarius humilis (Dana, 1851)}

Clibanarius humilis (Figure 18 B) - Mayotte, KUW fieldwork November 2009, St. 10, islet Quatre Frères, intertidal, 1 specimen in its shell, MNHN-Pg8489; St. 20a, islet M'tzamboro, north-eastern beach, intertidal, 1 male S1 2.4 mm, MNHN-Pg8503.

Distribution. - IWP. Eastern Africa, Mayotte (first record), Réunion, Mauritius, Rodriguez, Indonesia, Taiwan, Japan, New Caledonia, Wallis \& Futuna, Cook, French Polynesia. Intertidal.

Remarks. - A small-sized hermit crab that can be recognized by its color pattern as illustrated on figure $18 \mathrm{~B}$. It can be confused with Clibanarius ransoni Forest (1953) which is distinct by subtle differences in coloration, including a continuous lateral white band on P2 and P3 propodi. Calcinus ransoni is known in Vietnam, Indonesia, Taiwan, Wallis \& Futuna, French Polynesia but has still not be reported in WIO. 


\section{Clibanarius laevimanus Buitendijk, 1937}

Clibanarius laevimanus (Figure 18 C) - Mayotte, KUW fieldwork November 2009, St. 1, Trévani Beach, intertidal, as 'Clibanarius cf. striolatus, St. 1' in Bouchard et al., 2009: photo p. 96, 1 specimen in shell, MNHN-Pg8490; St. 2, from Trévani to Kangani Mangrove, intertidal, 1 specimen in its shell, MNHN-Pg8491; St. 6, Badamiers spillway, intertidal, 2 males S1 2.7 and $3.2 \mathrm{~mm}$, Lt about $20 \mathrm{~mm}, 1$ specimen in shell, MNHNPg8492, 36 juveniles in shells, MNHN-Pg8493; St. 10, islet Quatre Frères, intertidal, 2 specimens in shells, MNHN-Pg8494.

Distribution. - IWP. Eastern Africa (Somalia, Kenya), Madagascar, Mayotte (first record), Indonesia, Philippines.

Remarks. - In a first step (Bouchard et al., 2009: 96) these specimens were attributed to Clibanarius cf. striolatus (Dana, 1852). Clibanarius laevimanus and C. striolatus are both reported in WIO. They are closely related, with similar color pattern ( $c f$. color photographs of $C$. striolatus from Taiwan in McLaughlin et al., 2007 and from New Caledonia in Poupin \& Juncker, 2010), and characters used to separate them are in need of revision. However, with Rahayu \& Forest (1992) key and comments it seems more correct to attribute the specimens from Mayotte to $C$. laevimanus, based on the following characters: dactyl of the chela shorter than palm; dorsal surface of the chela (palm and dactyl) with low tubercles; P3 dactyl/propodus ratio greater than 1; and longitudinal color bands on P2, P3 discontinuous, not reaching distal parts of each segments. This last character is evident on partly discolored specimens examined after the fieldwork but it is less noticeable on live specimens with longitudinal bands of propodi almost reaching the distal margin (see Fig. $18 \mathrm{C}$ ).

\section{Clibanarius longitarsus (De Haan, 1849)}

Clibanarius longitarsus (Figure 18 D) - Mayotte, KUW fieldwork November 2009, St. 2, Kangani Mangrove, intertidal,1 male Sl 5.7 mm, Lt about 34 mm, 2 specimens in shells, MNHN-Pg8495; St. 6, Badamiers spillway, intertidal, 1 male Sl $2.9 \mathrm{~mm}$, Lt about $18 \mathrm{~mm}$, MNHN-Pg8496.

Distribution. - Widespread in the IWP. Red Sea, eastern Africa (Eritrea, Tanzania, Kenya, Mozambique), Madagascar, Mayotte (first record), Indonesia, Australia, Taiwan, Japan, New Caledonia. Intertidal and mangrove.

Remarks. - A large-sized hermit crab remarkable by blue sky longitudinal bands on ambulatory legs, as illustrated on figure $18 \mathrm{D}$. The species is ubiquitous. It prefers mangrove and sandy-muddy beaches but can be occasionally collected on rocky shores, in tide pools.

\section{Clibanarius rhabdodactylus Forest, 1953}

Clibanarius rhabdodactylus (Figure 19 A-B) - Mayotte, KUW fieldwork November 2009, St. 10, islet Quatre Frères, intertidal, as 'Clibanarius eurysternus, St. 10' in Bouchard et al., 2009: photo p. 96, 1 male S1 3.3 mm, Lc $7.7 \mathrm{~mm}$, Lt about $21 \mathrm{~mm}$, MNHN-Pg8497.

Distribution. - Indonesia and French Polynesia. Mayotte, first record in the Indian Ocean.

Remarks. - This is the first record of this species in the Indian Ocean. Its color pattern matches well that of the type species, as described by Forest (1953: 449). According to Forest (1953: 450), Clibanarius rhabdodactylus has affinities with C. signatus Heller, 1861 from Pakistan, Persian Gulf, Gulf of Oman, Gulf of Aden, and Red Sea, but it is distinct by having only 1 longitudinal strip on the ocular peduncle and 4 longitudinal stripes on the cephalic shield. A color photograph of C. signatus is in Moradmand \& Sari (2007: 36, fig. 2E). 


\section{Clibanarius virescens (Krauss, 1843)}

Clibanarius virescens (Figure 19 C-E) - BIOTAS collections, Glorioso, 3-7 May 2009, det. J. Poupin from photo - St. GLOR-14, fore reef platform; 13-14.5 m, specimen MEPA 1426, St. GLOR-16, reef flat all along coast of 'Grande Glorieuse', 0-3 m, specimens MEPA 1441, 1443, 1444; St. GLOR-12, exposed reef flat, abrasion platform, 1-3 m, specimen MEPA 1277; St. GLOR-14, fore reef platform, 13-14.5 m, specimens MEPA 1421, 1426; St. GLOR-16, reef flat all along coast of Grande Glorieuse, 0-3 m, specimen MEPA 1439, 1441-44. - Mayotte, KUW fieldwork November 2009, St. 3, Trévani fringing reef, 1-8 m, 1 male S1 $3.3 \mathrm{~mm}$ (discolored) MNHN-Pg8498; St. 6, Badamiers spillway, intertidal, 16 specimens in shell, MNHN-Pg8499; St. 20a, , 1 ovigerous female (eggs red) Sl $2.8 \mathrm{~mm}, 8$ specimens in shells, MNHN-Pg8500; St. 29, Mboianatsa beach, intertidal, 1 ovigerous female S1 2.9 mm, MNHN-Pg8501; St. 31, Bandrélé 'Musical beach', intertidal, 1 male Sl $3.5 \mathrm{~mm}$, Lt about $23 \mathrm{~mm}, 2$ males S1 2.8 and $3.2 \mathrm{~mm}$, Lt about 16 and $19 \mathrm{~mm}, 1$ female Sl $3.2 \mathrm{~mm}, 1$ ovigerous female S1 $3.2 \mathrm{~mm}$, Lt about $17 \mathrm{~mm}, 15$ specimens in shells, MNHN-Pg8502.

Distribution. - IWP. Eastern Africa (Somalia, Tanzania, Kenya, Mozambique, South Africa), Madagascar, Mayotte and Glorioso (first record), Seychelles, Réunion, Rodriguez, Indonesia, Thailand, Taiwan, Japan, Australia, New Caledonia, Fiji. Intertidal and subtidal.

Remarks. - A small-sized hermit crab, common in the intertidal. Specimens at Mayotte St. 31 were carefully compared with specimens from New Caledonia in MNHN collection. They are similar for morphology and coloration.

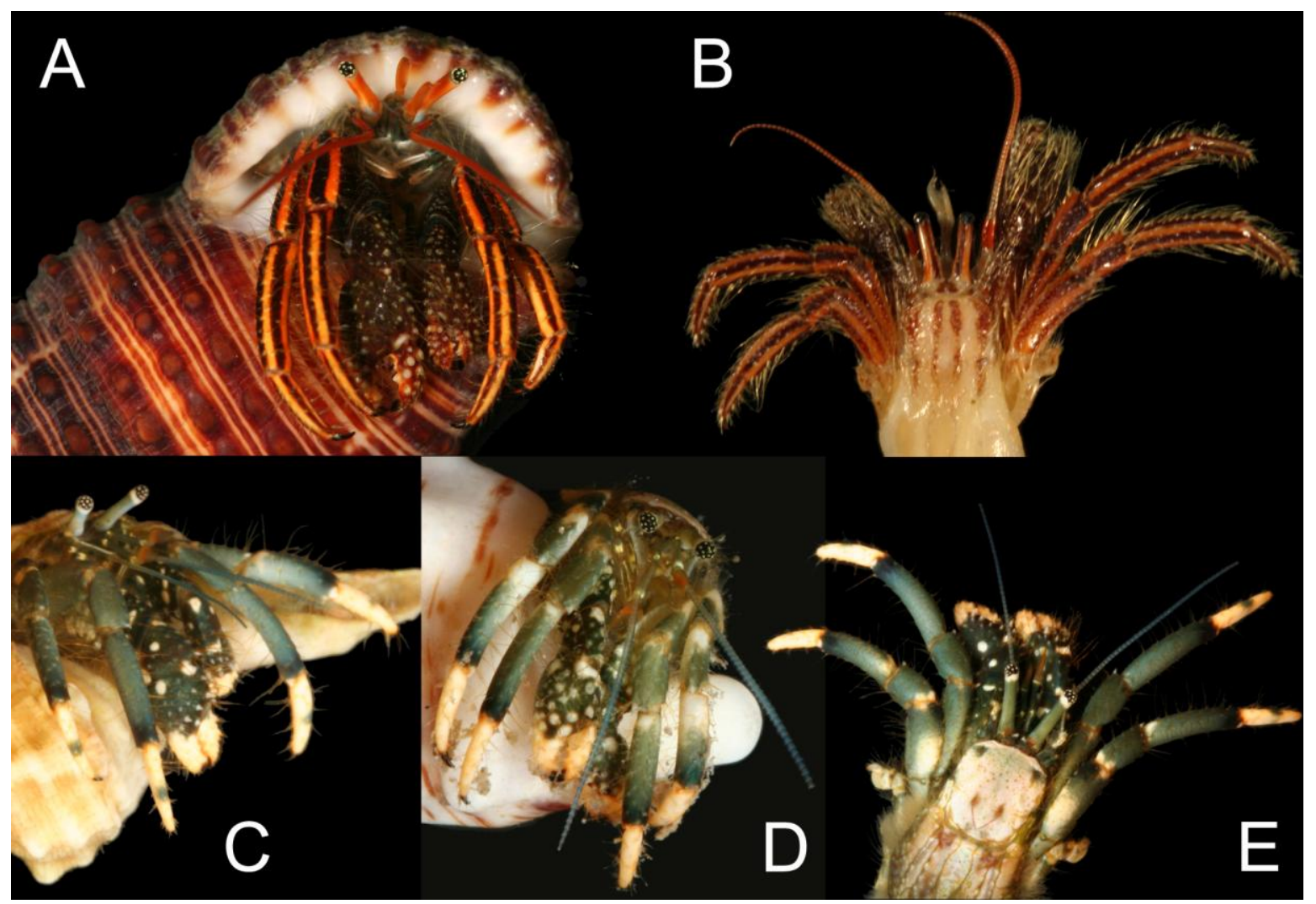

Figure 19. A-B) Clibanarius rhabdodactylus. 1 male Sl $3.3 \mathrm{~mm}$, Lc $7.7 \mathrm{~mm}$, Lt about $21 \mathrm{~mm}$, Mayotte, St. 10, MNHN-Pg8497, A) frontal view, specimen alive, B) dorsal view, preserved specimen, coloration slightly altered by preservative. C-E) Clibanarius virescens. 1 male S1 3.5 mm, Lt about 23 mm, Mayotte, St. 31, MNHN-Pg8502, C) lateral view, in shell, E) dorsal view; D) 1 specimen alive in shell S1 $3.0 \mathrm{~mm}$, frontal view, Mayotte, St. 20, MNHN-Pg8500. 


\section{Dardanus deformis (H. Milne Edwards, 1836)}

Pagurus deformis - Fourmanoir, 1955: 29 (Comoros: Mohéli, Numa Choa, 0.8 m). - Dardanus deformis (Figure 20 A-B) - Dechancé, 1964: 33 (Mayotte, coll. Crosnier, September 1959, 1 female 14 mm, MNHN). - BIOTAS collections, Glorioso, 3-7 May 2009, det. J. Poupin from photo, St. GLOR-12, exposed reef flat, abrasion platform, 1-3 m, specimen MEPA 1370. - Mayotte, KUW fieldwork November 2009, St. 12b, La Prévoyante reef, 6-12 m, 1 female S1 6.2 mm, Lt about 30 mm, MNHN-Pg8443; St. 38, Chiconi/Sada, bay, 1 female S1 9.1 $\mathrm{mm}$, Lt about $60 \mathrm{~mm}$, in giant land snail (Achatina) shell, with anemones on the shell, MNHN-Pg8444.

Distribution. - IWP. Red Sea, eastern Africa (Somalia, Kenya, Tanzania, Mozambique), Madagascar, Comoros, Mayotte, Glorioso, Seychelles, Réunion, Mauritius, Maldives, Taiwan, Australia, Philippines, Mariana, Fiji, Cook, French Polynesia, Hawaii. Subtidal.

Remarks. - A medium-sized hermit crab common in shallow waters. On preserved specimens it is distinct by the aspect of outer face of $\mathrm{P} 3$ propodus with a prominent longitudinal ridge as illustrated on figure $20 \mathrm{~A}$. When diving at night it can be easily recognized by the bright green color of its corneas (see Fig. 20 B).

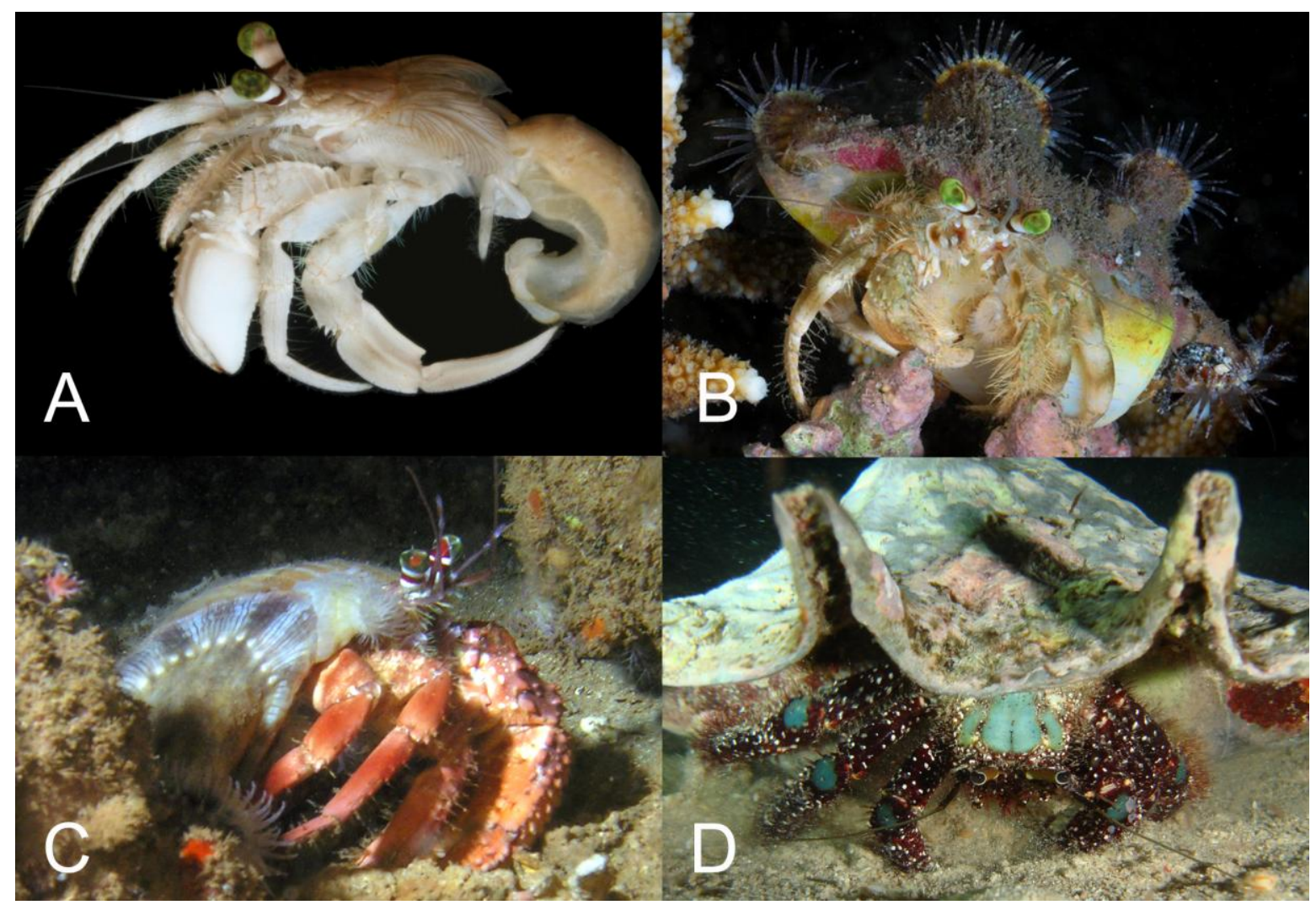

Figure 20. A-B) Dardanus deformis. A) lateral view showing aspect of outer face of P3 propodus, 1 female, Sl $6.2 \mathrm{~mm}$, Lt about $30 \mathrm{~mm}$, Mayotte, St. 12, MNHN-Pg8443; B) Specimen in situ, showing green corneas, Réunion Island, copyright L. Bêche. C) Dardanus gemmatus, Mayotte lagoon at night, copyright M. Allaria. D) Dardanus guttatus, Mayotte, St. 12, La Prévoyante reef, 6-11 m (not collected). 


\section{Dardanus gemmatus (H. Milne Edwards, 1848)}

Dardanus gemmatus - Dechancé, 1964: 33 (M'tzamboro reef, intertidal, coll. Crosnier September 1959, 1 male $15 \mathrm{~mm}, \mathrm{MNHN}$ ). - Photo M. Allaria, Mayotte, lagoon at night, not collected (Figure 20 C).

Distribution. - IWP. Madagascar, Mayotte, Réunion, Mauritius, Australia, Japan, Mariana, New Caledonia, Loyalty Islands, French Polynesia, Hawaii.

Remarks. - A medium to large-sized hermit crab. It can be confused with Dardanus pedunculatus with similar red rings on the ocular peduncles but it is distinct by the presence of tubercles over the entire outer face of the big chela. In $D$. pedunculatus this face can have few tubercles on its upper half but is smooth on its lower half (see Fig. 21 E).

\section{Dardanus guttatus (Olivier, 1812)}

Dardanus guttatus (Figure 3 B, 20 D) - Dechancé, 1964: 33 (Mayotte, coll. Crosnier, September 1959, inner barrier reef, 1 male $45 \mathrm{~mm}$, dredge on fine sand bottom, $50 \mathrm{~m}, 1$ male $7 \mathrm{~mm}, \mathrm{MNHN}$ ). - BIOTAS collections, Glorioso, 3-7 May 2009, det. J. Poupin from photo, St. GLOR-4, patch reef, near anchorage, 3-6 m, specimen MEPA 1959; St. GLOR-12, exposed reef flat, abrasion platform, 1-3 m, specimen MEPA 1269. - Mayotte, KUW fieldwork November 2009, St. 12c, La Prévoyante reef at night, 6-12 m, in situ photo only, specimen not collected; St. 17, North reef, 22 m, field notes only, no specimen collected - Photo Y. Gildas, Mayotte Internet [7].

Distribution. - Common in the IWP. Eastern Africa (Somalia, Kenya, Tanzania, Mozambique), Madagascar, Mayotte, Glorioso, Seychelles, Chagos, Indonesia, China Sea, Taiwan, Mariana, New Guinea, Australia, New Caledonia, Loyalty, Wallis \& Futuna, Samoa, Cook, French Polynesia. Subtidal to about $20 \mathrm{~m}$.

Remarks. - A medium to large-sized hermit crab, sometimes called the 'blue-knee hermit crab'. It can be easily recognized during a dive at night by the greenish-blue patches on the carpi of chelipeds and ambulatory legs (see Fig. 20 D).

\section{Dardanus lagopodes (Forskål, 1775)}

Dardanus sanguinolentus - Dechancé, 1964: 34 (Mayotte, coll. Crosnier, dredge in lagoon, 51 m, MNHN; Dardanus sanguinolentus (Quoy \& Gaimard, 1825) is a junior synonym of D. lagopodes). - Dardanus lagopodes (Figures 3 C, 21 A-C) - BIOTAS collections, Glorioso, 3-7 May 2009, det. J. Poupin from photo, St. GLOR-1, patch reef, near anchorage, 2-4 m, specimen MEPA 884; St. GLOR-2, reef platform and shallow canyons with dead Acropora digitifera head, 7-14 m, specimens MEPA 922, 930, 943, 1949; St. GLOR-4, patch reef, near anchorage, 3-6 m, specimens MEPA 1954, 1955, 1958; St. GLOR-12, exposed reef flat, abrasion platform, 1-3 m, specimen MEPA 1276; St. GLOR-18, fore reef platform, 13-14.5 m, specimen MEPA 1266. - Mayotte, KUW fieldwork November 2009, St. 3b, Trévani fringing reef at night, 1-8 m, photo in situ only, specimen not collected; St. 4, La Prévoyante reef, 6-10 m, field observation only, no specimen collected; St. 5, North east reef, seagrass bed, $1 \mathrm{~m}, 1$ male Sl $6.0 \mathrm{~mm}$, Lt about $50 \mathrm{~mm}$, red carpi form, 1 male S1 $5.4 \mathrm{~mm}$, Lt about 35 mm, brown carpi form, MNHN-Pg8445; St. 14, La Prudente bank, 15-17 m, field observation; St. 15, islet Mtsamboro, $1 \mathrm{~m}$, field observation; St. 19, islet Handrema, 6-10 m, 1 male Sl $1.8 \mathrm{~mm}$, Lt about $12 \mathrm{~mm}$; St. 20a, islet M'tzamboro, $1 \mathrm{~m}, 1$ male S1 $6.9 \mathrm{~mm}$, Lt about 47 mm, MNHN-Pg8446; St. 23, Choizil pass 'Patate à Teddy', 15-30 m, 1 male Sl $4.8 \mathrm{~mm}$, Lt about $33 \mathrm{~mm}$, 1 ovigerous female Sl $5.1 \mathrm{~mm}$, Lt $34 \mathrm{~mm}$, MNHNPg8447; St. 25, islet M'tzamboro, 15-20 m, field observation; St. 26, Mutsumbatsou reef flat, low intertidal, 1 male Sl. $1.9 \mathrm{~mm}$, Lt about $13 \mathrm{~mm}$; St. 31, Bandrélé 'Musical beach', low intertidal, 1 male Sl $1.8 \mathrm{~mm}$, Lt about 11.8 mm, MNHN-Pg8532; St. 35, Surprise reef, Longoni pass, 4-25 m, 1 ovigerous female S1 4.7 mm, Lt about $33 \mathrm{~mm}, \mathrm{MNHN}-\mathrm{Pg} 8448$. 
Distribution. - Widespread in the IWP. Red Sea, Gulf of Aden, Persian Gulf, Eastern Africa, Madagascar, Mayotte, Glorioso, Seychelles, Réunion, Mauritius, Maldives, Malaysia, Indonesia, Taiwan, Japan, Philippines, Mariana, New Guinea, Australia, New Caledonia, Loyalty, Wallis \& Futuna, Samoa, Cook, French Polynesia, Hawaii. Low intertidal to subtidal (25-30 m).

Remarks. - A medium-sized hermit crab very common in Mayotte. Juveniles specimens from Mayotte at St. 19, 26, 31 are attributed with hesitation to Dardanus lagopodes. They still have remains of coloration on ambulatory legs that are similar to the adults but the abdomen bears pleopods that are not seen in the adults: four on the left side and three (smaller) on the right side. As often reported for this species (e.g. McLaughlin et al., 2007: 91; Poupin \& Juncker, 2010: 231) two color morphs have been observed in Mayotte, carpi of chelipeds and ambulatory legs being either brown or bright red (compare Fig. 21 B-C). According to M. Malay (pers. com.) the blue knee and red knee morphs of specimens collected in the Philippines (Panglao) are very different genetically, and a few morphological differences have been also noticed. In a near future these two morphs could therefore be treated as distinct species.

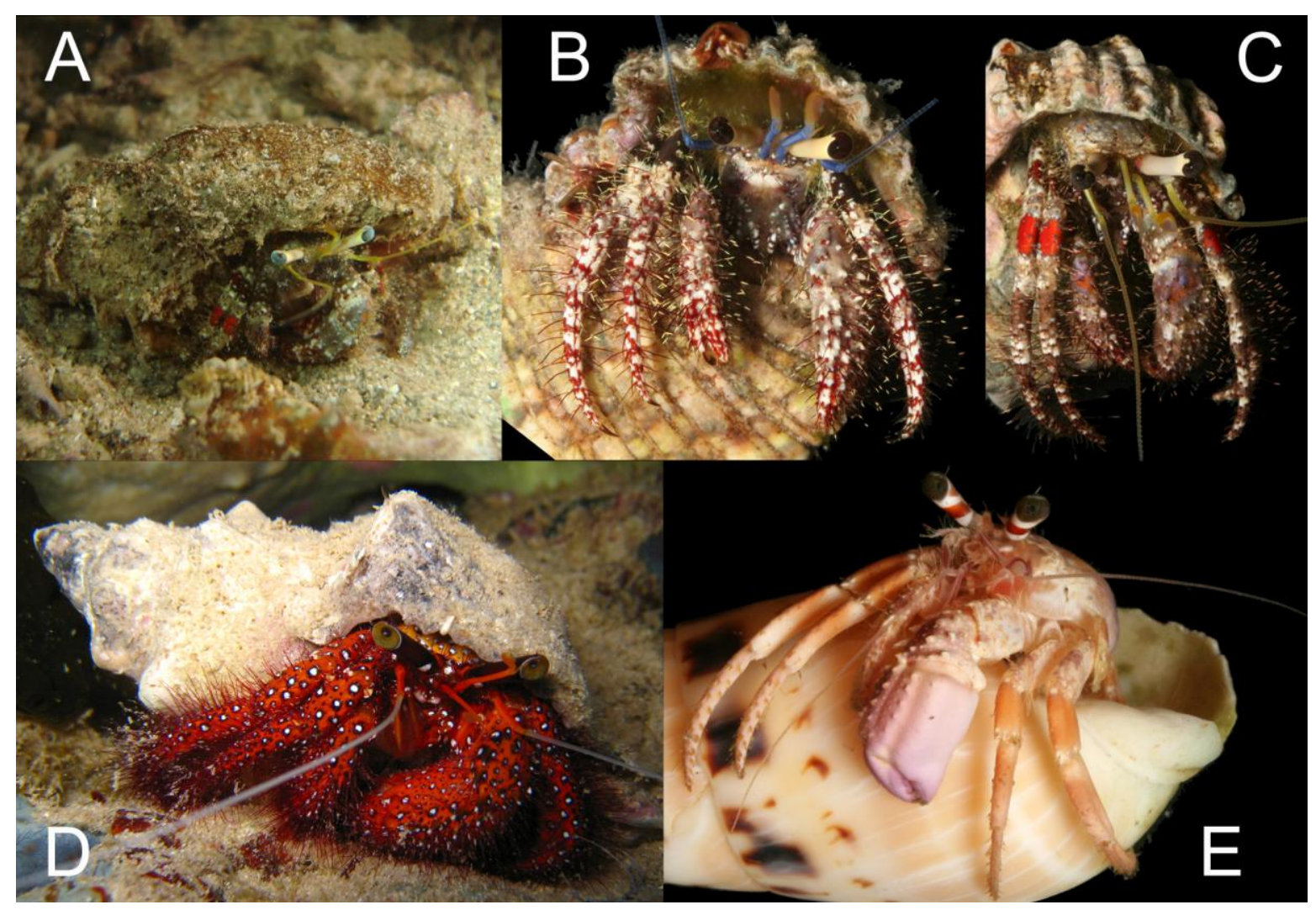

Figure 21. A-C) Dardanus lagopodes, Mayotte. A) Specimen in situ, at night, St. 3b, Trévani reef, 1-8 m; St. 5, North east reef, seagrass bed, $1 \mathrm{~m}$, MNHN-Pg8445; B) 1 male S1 5.4 mm, brown carpi coloration; C) 1 male S1 $6.0 \mathrm{~mm}$, red carpi coloration. D) Dardanus megistos, Mayotte, dive at night, August 25, 2009, $10 \mathrm{~m}$, buoy $\mathrm{n}^{\circ}$ 6, S pass, Copyright M. Deuss. E) Dardanus pedunculatus, islet M'tzamboro, $1 \mathrm{~m}, 1$ male S1. $7.3 \mathrm{~mm}$, Lt about $46 \mathrm{~mm}$, Mayotte, St. 20a, MNHN-Pg8450. 


\section{Dardanus megistos (Herbst, 1804)}

Dardanus megistos (Figure 21 D) - Coll. Anker \& Michonneau, 2008, St. MAY08-St1, Mboianatsa reef, UF 13605. - Mayotte, KUW fieldwork November 2009, St. 20a, islet M'tzamboro, $1 \mathrm{~m}, 1$ male S1 $4.8 \mathrm{~mm}$, Lc 8.8 $\mathrm{mm}$, Lt about $32 \mathrm{~mm}$, MNHN-Pg8449; St. 25, islet M'tzamboro, 15-20 m, photo in situ only. - Others observations from photos: M. Deuss, dive at night, 25 August 2009, $10 \mathrm{~m}$, buoy n ${ }^{\circ} 6, \mathrm{~S}$ pass (Vivier site); B. Pineau, Mayotte lagoon at night.

Distribution. - Widespread in the IWP. Red Sea, Eastern Africa (Eritrea, Somalia, Tanzania, Kenya, Mozambique, South Africa), Europa, Madagascar, Mayotte, Seychelles, Réunion, Mauritius, Maldives, Indonesia, China Sea, Taiwan, Japan, Mariana, Australia, New Caledonia, Wallis \& Futuna, Cook, French Polynesia, Hawaii. Subtidal to 50-100 m.

Remarks. - A medium to large-sized hermit crab. This is an ubiquitous species that can be easily recognized during a dive at night based on its bright red coloration with white spots ringed in black.

\section{Dardanus pedunculatus (Herbst, 1804)}

Dardanus asper - Dechancé, 1964: 33 (Mayotte, Numa Choa, 1 female 17 mm, MNHN; Dardanus asper (de Haan, 1849) is a junior synonym of $D$. pedunculatus). - Dardanus pedunculatus (Figure $21 \mathrm{E}$ ) - Mayotte, KUW fieldwork November 2009, St. 20a, islet M'tzamboro, $1 \mathrm{~m}, 1$ male S1 $7.3 \mathrm{~mm}$, Lc $15.3 \mathrm{~mm}$, Lt about $46 \mathrm{~mm}$, MNHN-Pg8450.

Distribution. - IWP. Red Sea, eastern Africa (Somalia, Kenya, Mozambique), Madagascar, Mayotte, Seychelles, Indonesia, Australia, Taiwan, Japan, Philippines, New Caledonia, Cook, French Polynesia, Hawaii. Subtidal to $100 \mathrm{~m}$.

Remarks. - Medium to large-sized hermit crab. By its coloration it has affinities with D. gemmatus. It is distinct by the aspect of outer face of its big chela (see under D. gemmatus).

\section{Dardanus scutellatus (H. Milne Edwards, 1848)}

Dardanus scutellatus (Figures 3 A, 22 A-C) - Mayotte, KUW fieldwork November 2009, St. 5, Great north east reef, seagrass bed, $1 \mathrm{~m}, 2$ males Sl 6.7 and $7.5 \mathrm{~mm}, 1$ female Sl $6.2 \mathrm{~mm}, \mathrm{Lt}$ about 40-50 mm, MNHN-Pg8451; St. 20a, islet M'tzamboro, $1 \mathrm{~m}, 1$ male S1 $7.3 \mathrm{~mm}$, Lt about $46 \mathrm{~mm}, 1$ ovigerous female S1 $5.6 \mathrm{~mm}$, Lt about 43 mm, MNHN-Pg8452.

Distribution. IWP. Eastern Africa (Somalia, Kenya, Mozambique, Tanzania), Madagascar, Mayotte (first record), Mauritius, Maldives, Indonesia, Philippines, Mariana, Australia, New Caledonia, Fiji, Tuvalu, Wallis \& Futuna, Tonga, Cook, French Polynesia.

Remarks. - Medium to large-sized hermit. It can be recognized during a dive by its pale blue eyes and longitudinal black-maroon stripes on basal segments of antennules and antennae, as illustrated on figure $22 \mathrm{~B}$ C.

\section{Diogenes pallescens Whitelegge, 1897}

Diogenes pallescens (Figure 22 E) - Mayotte, KUW fieldwork November 2009, St. 3a, Trévani fringing reef, 1$8 \mathrm{~m}, 1$ male S1 $2.0 \mathrm{~mm}$, Lt about $16 \mathrm{~mm}$, MNHN-Pg8516; St. 8, Lagoon close to Great north-eastern reef, 6-8 m, 1 male Sl $2.1 \mathrm{~mm}$, Lt about $14 \mathrm{~mm}$, MNHN-Pg8515; St. 20a, islet M'tzamboro, intertidal, 1 male S1 $1.9 \mathrm{~mm}$, MNHN-Pg8513; St. 20b, islet M'tzamboro, 10-15 m, 1 ovigerous female S1 1.66 mm MNHN-Pg8546 (in Hydrozoa, spines of lateral margins of carapace reduced); St. 26b, Mutsumbatsou reef flat, intertidal, 1 ovigerous female S1 2.2 mm, MNHN-Pg8514; St. 27, islet Mbouzi, 4-20 m, 1 male Sl $3.1 \mathrm{~mm}$, Lc $6 \mathrm{~mm}$, Lt about $23 \mathrm{~mm}$, as 'Paguridae indéterminé' in Bouchard et al., 2009, photo p. 101, 1 ovigerous female S1 $3.3 \mathrm{~mm}$ (broken), MNHN-Pg8517. 
Distribution. - IWP. Red Sea, eastern Africa (Eritrea, Kenya, Mozambique), Mayotte (first record), Indonesia, Marianas, Papua New Guinea, Tuvalu (Funafuti), French Polynesia.

Remarks. - Some specimens, such as St. 20a, 1 male Sl $1.9 \mathrm{~mm}$ (MNHN-Pg8513), key out to Diogenes leptocerus Forest, 1957 with Rahayu \& Forest (1995) key, based on the distal armature of P2/P3 carpi: a single dorso-distal spine on P2/P3 carpi instead of two on P2 carpus and 1-2 on P3 carpus, in D. pallescens. Diogenes leptocerus has been reported from Kenya by Reay \& Haig (1990) and could therefore be present in Mayotte region. However, according to Forest (1957: 528), the inter-ocular scale of D. leptocerus is triangular with a single terminal spine whereas it is elongated and bi-spinose in D. pallescens. This last character has been verified on all specimens examined from Mayotte and they are consequently all attributed to $D$. pallescens. This species has been often reported in the literature under Diogenes gardineri Alcock, 1905 or Diogenes serenei Forest, 1956, two species that are now considered by McLaughlin as junior synonyms of $D$. pallescens (see WoRMS database [4]).

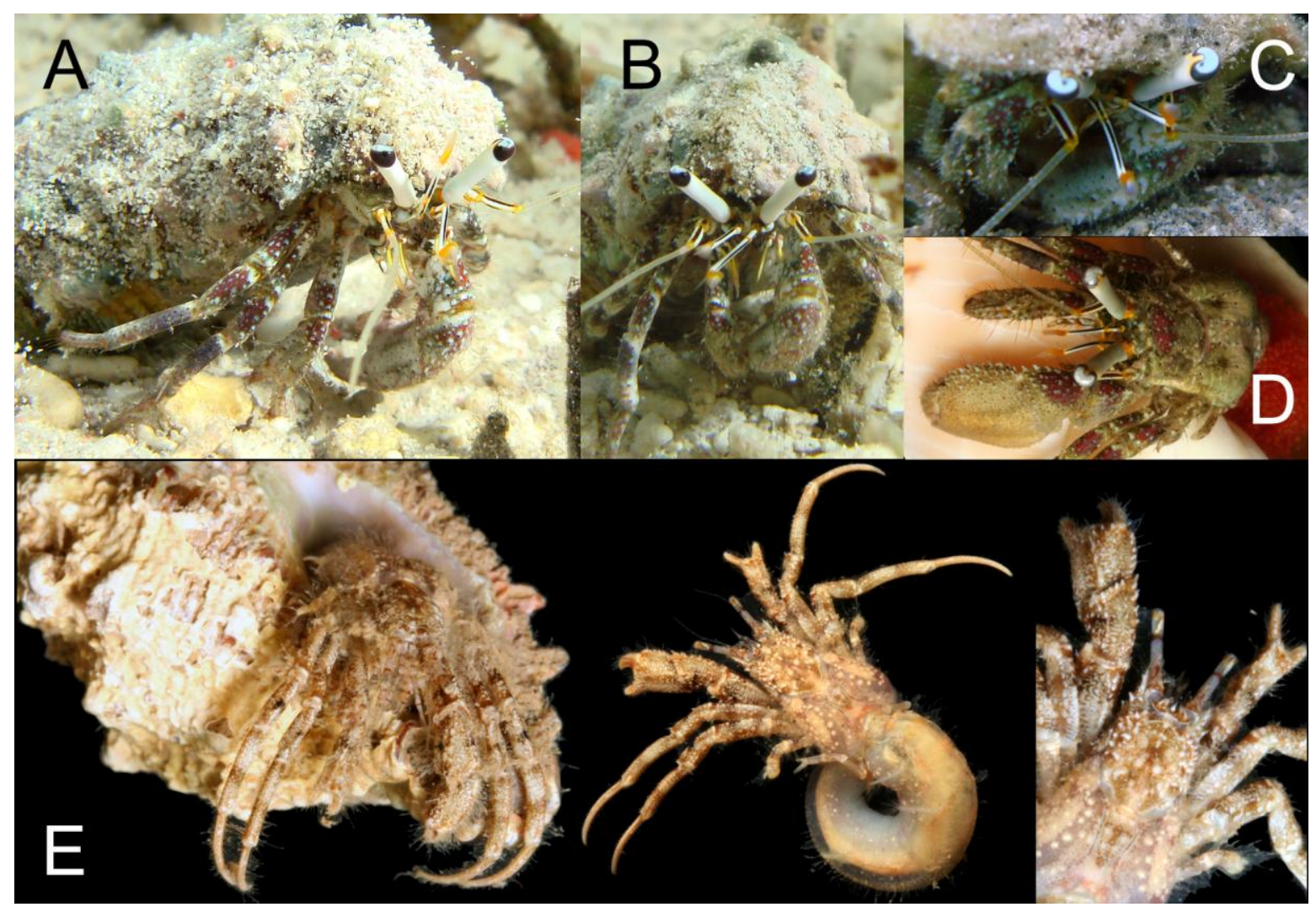

Figure 22. A-D) Dardanus scutellatus. A-B) 1 male, Mayotte, St. 5, MNHN-Pg8451, in situ, lateral and frontal view; C-D) 1 ovigerous female S1 5.6 mm, Mayotte, St. 20a, MNHN-Pg8452, C) in situ, D) detail of ocular peduncles and chelae after cleaning. E) Diogenes pallescens, 1 male S1 $3.1 \mathrm{~mm}$, Lc $6 \mathrm{~mm}$, Mayotte, St. 27, MNHN-Pg8517, frontal view in shell, dorsal view, and detail of larger chela, shield and ocular peduncles. 


\section{Paguristes palythophilus Ortmann, 1892}

Paguristes palythophilus - Rahayu, 2007: 521 (Mozambique channel, BENTHEDI Expedition, St. DR 38, Mayotte, east of Bandrélé reef, $12^{\circ} 54.8^{\prime} \mathrm{S}, 4^{\circ} 15.6^{\prime} \mathrm{E}, 200-500 \mathrm{~m}, 26$ March 1977, 1 female S1 $3.0 \mathrm{~mm}$, MNHN).

Distribution. - IWP. Mayotte, Madagascar, Indonesia, Taiwan, Japan. 80-510 m.

\section{Pseudopaguristes laurentae (Morgan \& Forest, 1991)}

Pseudopaguristes laurentae - Rahayu, 2007: 526 (BENTHEDI Expedition, West of Glorioso, St. DR 8, $11^{\circ} 29.2^{\prime} \mathrm{S}, 47^{\circ} 18.2^{\prime} \mathrm{E}, 250 \mathrm{~m}, 19$ March 1977, 1 female Sl $1.5 \mathrm{~mm}, 2$ males Sl 1.8 and $2.0 \mathrm{~mm}$, MNHN, 1 male S1 $1.8 \mathrm{~mm}, 1$ female Sl $2.2 \mathrm{~mm}, 1$ ovigerous female S1 $2.0 \mathrm{~mm}$ (MNHN); Mayotte, east of Bandrélé reef, St. DR 38, 12 $2^{\circ} 54.8^{\prime}$ S, $45^{\circ} 15.6^{\prime}$ E, 200-500 m, 26 March 1977, 1 female Sl 3.0 mm, MNHN; West of Glorioso, St. F 98, $11^{\circ} 35.5^{\prime} \mathrm{S}, 47^{\circ} 16.5^{\prime} \mathrm{E}, 280-460 \mathrm{~m}, 7$ March 1977, 1 male Sl 3.0 mm (MNHN).

Distribution. - IWP. Madagascar, Glorioso, Réunion, Australia, Indonesia, Japan. 121-675 m..

\section{FAMILY PAGURIDAE}

Several small pagurids from Mayotte remain undetermined to species level for this study. These include one record from the literature, Catapagurus sp. in Dechancé, 1964, and three species collected during KUW 2009 fieldwork (see below, under Paguridae spp.).

\section{Paguridae spp.}

Paguridae spp. - Mayotte, KUW fieldwork November 2009 - Three groups separated according to aspect of male sexual tube - a) 'Coxa of P5 with long sexual tube' - St. 12, La Prévoyante reef, 6-12 m, 1 male S1 1.7 mm, Lt about 15 mm, MNHN-Pg8518; St. 14, La Prudente bank, 15-17 m, 1 male S1 $1.1 \mathrm{~mm}, 1$ ovigerous female Sl 0.9 mm, 1 female with post-larvae, Sl $1.1 \mathrm{~mm}$, in shell, 1 female Sl $0.8 \mathrm{~mm}$, MNHN-Pg8519; St. 17, North reef, 22 m, 1 male Sl 1.5 mm MNHN-Pg8545; St. 25, islet M'tzamboro, 15-20 m, 1 male Sl $1.1 \mathrm{~mm}$, Lt about 5.9 mm, MNHN-Pg8520 - b) 'Coxa of P5 with long sexual tube 2' - St. 17, North reef, $22 \mathrm{~m}, 1$ male and 1 sp. in shells, MNHN-Pg8544. - c) 'Coxa of P5 with short sexual tube' - St. 8, Lagoon close to Great northeastern reef, 6-8 m, 1 male S1 1.4 mm, MNHN-Pg8521.

Remarks. - These specimens, all characterized by the presence of a sexual tube on coxa of male right P5, were pre-identified, just after the fieldwork, as Boninpagurus aff. acanthocheles Asakura \& Tachikawa, 2004. Careful examination of the lot by T. Komai, in June 2011, has revealed that it included in fact two specimens that have affinities with Micropagurus polynesiensis (Nobili, 1906), St. 17 (MNHN-Pg8544), and two new species, Cestopagurus caeruleus Komai \& Poupin, 2012, St. 12 (MNHN-Pg8518, Fig. 23 A), St. 14, 17 (MNHN-Pg8545), St. 25 (MNHN-Pg8520), and Trichopagurus asper Komai \& Poupin, 2012, St. 8 (MNHNPg8521). The two new species will be included in a separate study (Komai \& Poupin, 2012)

\section{Anapagrides reesei (McLaughlin, 1986)}

Anapagrides reesei - Mayotte, KUW fieldwork November 2009, St. 25, islet M'tzamboro, 15-20 m, 1 female Sl $1.4 \mathrm{~mm}, \mathrm{MNHN}$.

Distribution - IWP. Hawaii, type locality. Now Mayotte, first record in IO.

Remarks. - Small-sized specimen initially in the 'Paguridae spp.' lot. It has been correctly identified by T. Komai, June 2011. 


\section{Catapagurus sp. in Dechancé, 1964}

Catapagurus sp. - Dechancé, 1964: 37 (Mayotte, coll. Crosnier, dredge, sand, 49-56 m, sable, 2 ovigerous females 2.9 et $3.3 \mathrm{~mm}$, MNHN).

Remarks. - According to Dechancé (1964: 37) this species has affinities with Catapagurus ensifer Henderson, 1893, already reported in WIO and to Catapagurus granulatus Edmondson, 1951, currently known only from Hawaii.

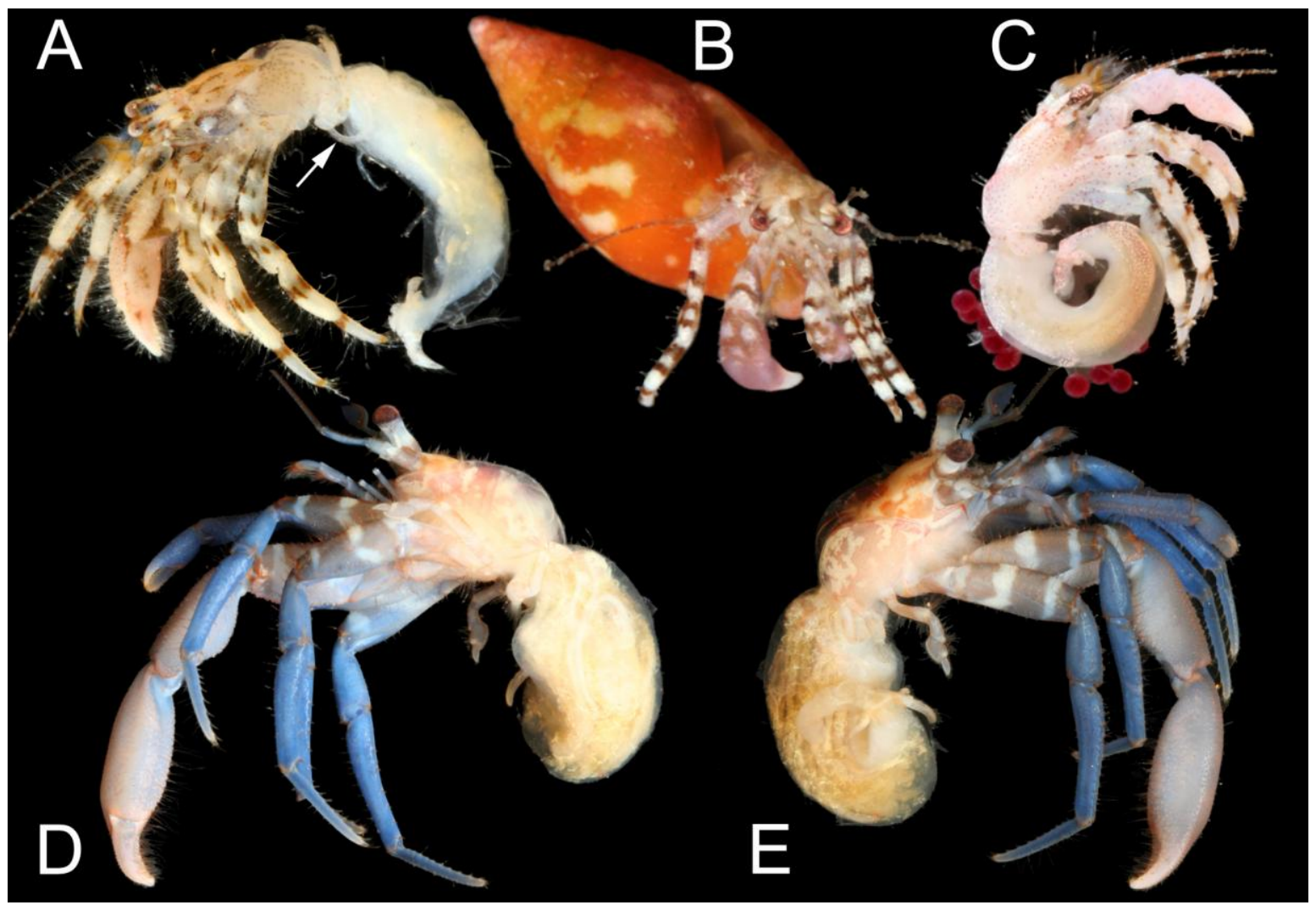

Figure 23. A) Cestopagurus caeruleus., 1 male Sl $1.7 \mathrm{~mm}$, Lt about $15 \mathrm{~mm}$, Mayotte, St. 12, MNHN-Pg8518. B-C) Pagurixus carinimanus, Mayotte. B) specimen alive, St. 23, MNHNPg8524; C) 1 ovigerous female Sl $1.5 \mathrm{~mm}$, Lt about $9 \mathrm{~mm}$, St. 14, MNHN-Pg8523. D-E) Pagurixus nomurai, 1 male Sl $4.1 \mathrm{~mm}$, Lt about $32 \mathrm{~mm}$, Mayotte, St. 25, MNHN-Pg8525, lateral view, D) left side, E) right side.

\section{Pagurixus carinimanus Komai \& Osawa, 2006}

Pagurixus carinimanus (Figure 23 B-C) - BIOTAS collections, Glorioso, 3-7 May 2009, det. J. Poupin from photo, St. GLOR-5, reef slope East side, 17 m, specimen MEPA 1886; St. GLOR-17, reef front side and dead Acropora head, 8 m, specimen MEPA 1559; St. GLOR-19, fore reef platform and dead small Pocillopora, 1314 m, specimen MEPA 1623. - Mayotte, KUW fieldwork November 2009, St. 14, La Prudente bank, 15-17 m, 1 male S1 $1.9 \mathrm{~mm}$ (abdomen apart), 1 male S1 $1.0 \mathrm{~mm}$ (small chela apart), 1 ovigerous female S1 $1.5 \mathrm{~mm}, \mathrm{Lt}$ about 9 mm, 1 female S1 1.3 mm, MNHN-Pg8523; St. 23, Choizil pass 'Patate à Teddy', 15-30 m, 1 specimen in shell, MNHN-Pg8524.

Distribution - IWP. Western Pacific: Japan, Guam, Philippines. Also Mayotte and Glorioso (first record in WIO). 
Remarks. - This species has two fine longitudinal stripes disposed mesially and laterally on the ocular peduncles. In females, the eggs are red garnet as illustrated on figure $23 \mathrm{C}$. The chelae have the keeled aspect described for $P$. carinimanus by Komai \& Osawa (2006). The overall coloration as illustrated here on figure 23 B-C is also similar to that illustrated for P. carinimanus by Komai \& Osawa (2006: 101, fig. 45B). While this study was submitted, a few specimens initially kept in their shells (MNHN-Pg8524) were separated as distinct species by T. Komai (MNHN, June 2011: Pagurixus patiae, Clibanarius sp. juvenile).

\section{Pagurixus nomurai Komai \& Asakura, 1995}

Pagurixus nomurai (Figure 23 D-E) - Mayotte, KUW fieldwork November 2009, St. 25, islet M'tzamboro, 15$20 \mathrm{~m}, 1$ male Sl $4.1 \mathrm{~mm}$, Lc $6.2 \mathrm{~mm}$, Lt about $32 \mathrm{~mm}$, as 'Pagurixus cf. nomurai' in Bouchard et al., 2009, photo p. 101, MNHN-Pg8525.

Distribution. - IWP. Mayotte (first record), Réunion, Northwestern Australia, Japan, Guam, Samoa, Cook, French Polynesia. Subtidal to $60 \mathrm{~m}$.

Remarks. - Morphology and color pattern are in accordance with description and color photo in Komai \& Osawa (2006). In the WIO this species was already reported from Réunion by Poupin (2009: 125) based on photograph only (see Poupin \& Massoukou website [6]).

\section{Pagurixus patiae Komai, 2006}

Pagurixus patiae - Mayotte, KUW fieldwork November 2009, St. 23, Choizil pass, 'Patate à Teddy', 15-20 m, 1 male in shell, MNHN-Pg8556.

Distribution. IWP. Mayotte (first record in IO) and Japan (Okinawa Island and Iriomote Island, Ryukyu Islands). Intertidal to subtidal (15-20 m).

Remarks. - This small male was first confused with Pagurixus carinimanus (St. 23, MNHN Pg8524). It has been correctly identified by T. Komai in MNHN, June 2011. A color photograph of this species is in Osawa \& Komai (2007, fig. 5C-D) with remarks on morphology and the observation that it is sympatric with congeners such as Pagurixus carinimanus (also observed in this study) and P. ruber.

\section{Pagurixus purpureus Komai \& Okuno, 2009}

Pagurixus purpureus (Figure 24 D) - Mayotte, KUW fieldwork November 2009, St. 21b, islet Choizil, 15-20 m, 1 ovigerous female S1 1.6 mm, 1 female S1 1.9 mm, MNHN-Pg8533; St. 23, Choizil pass, 'Patate à Teddy', 1520 m, 1 male S1 1.6 mm, MNHN-Pg8534; St. 25, islet M'tzamboro, 15-20 m, 1 male Sl $2.2 \mathrm{~mm}$, Lt about 12 $\mathrm{mm}, \mathrm{MNHN}-\mathrm{Pg} 8535$.

Distribution. IWP. Mayotte (first record in WIO) and Japan (Izu Islands). Subtidal to 15-20 m.

Remarks. - Small-sized hermit crabs collected with larger specimens of the genus Pylopaguropsis. They can be recognized quickly based on their coloration as illustrated on figure $24 \mathrm{D}$ similar to that of types specimens illustrated by Komai \& Okuno (2009: 153, fig. 9A-B).

\section{Pagurixus ruber Komai \& Osawa, 2006}

Pagurixus ruber (Figure 24 A) - Mayotte, KUW fieldwork November 2009, St. 25, islet M'tzamboro, 15-20 m, 1 male Sl $2.1 \mathrm{~mm}$, Lc $3.5 \mathrm{~mm}$, Lt about $13 \mathrm{~mm}$, as 'Pagurixus indéterminé' in Bouchard et al., 2009, photo p. 101, MNHN-Pg8526.

Distribution. - IWP. Mayotte (first record in WIO), Maldives, Taiwan, Japan, Guam, French Polynesia. Subtidal to $15-20 \mathrm{~m}$.

Remarks. - A small-sized hermit crab that can be recognized by its color pattern with chelipeds and ambulatory legs purplish red and distal parts of dactyli and propodi of ambulatory legs white. 


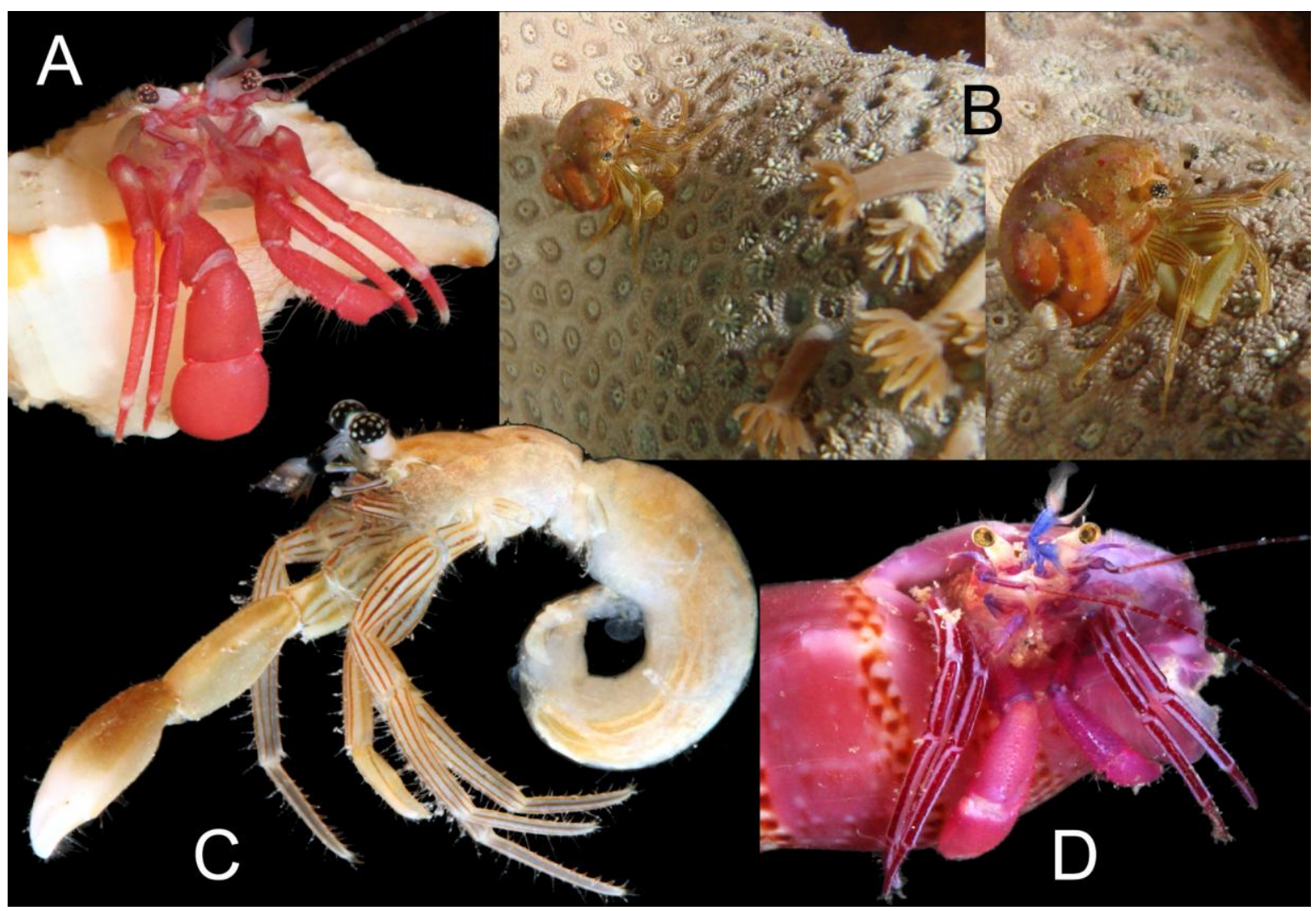

Figure 24. A) Pagurixus ruber, 1 male Sl $2.1 \mathrm{~mm}$, Lc $3.5 \mathrm{~mm}$, Lt about $13 \mathrm{~mm}$, Mayotte, St. 25, MNHN-Pg8526. B-C) Pagurixus rubrovittatus, 1 male S1 $2.3 \mathrm{~mm}$, Lc $4.7 \mathrm{~mm}$, Lt about 21 mm, Mayotte, St. 12, MNHN-Pg8527, B) specimen in situ, C) same specimen, left lateral face. D) Pagurixus purpureus, 1 female S1 1.9 mm, Mayotte, St. 21b, MNHN-Pg8533.

\section{Pagurixus rubrovittatus Komai, 2010}

Pagurixus rubrovittatus (Figure 24 B-C) - Mayotte, KUW fieldwork November 2009, St. 12, La Prévoyante reef, 6-12 m, 1 male Sl $2.3 \mathrm{~mm}$, Lc $4.7 \mathrm{~mm}$, Lt about $21 \mathrm{~mm}$, as 'Pagurixus maorus and P. cf. maorus' in Bouchard et al., 2009, photos p. 100, MNHN-Pg8527; St. 24, islet Handrema, 6-12 m, 1 male S1 3.3 mm (abdomen and chelae missing) MNHN-Pg8528; St. 27, islet Mbouzi, 4-20 m, 1 female S1 3.0 mm, Lc 6.0 mm, Lt about $26 \mathrm{~mm}$, MNHN-Pg8529; St. 28, islet Mbouini, 3-20 m, 1 ovigerous female S1 $2.2 \mathrm{~mm}$, big chela broken, MNHN-Pg8530; St. 30, Rani reef, 3-15 m, 1 male Sl 1.9 mm, in shell, 1 male S1 2.5 mm, Lt about 22 $\mathrm{mm}, \mathrm{MNHN}-\mathrm{Pg} 8531$.

Distribution. - Mayotte (first record in IO), New Caledonia, Chesterfield, 3-25 m.

Remarks. - These specimens were first attributed to Pagurixus aff. maorus. While this study was submitted they were correctly identified to P. rubrovittatus, by T. Komai (MNHN, June 2011). Pagurixus rubrovittatus closely resembles $P$. maorus in morphology and coloration by can be easily separated by absence of longitudinal rows of setae on the ventral surface of the ultimate segment of the antennular peduncle. Others morphological characters useful to separate both species are in Komai (2010). 


\section{Pagurus hirtimanus (Miers, 1880)}

Eupagurus janitor - Fourmanoir, 1955: 29 (Mayotte, Bandéli, 1 m). - Pagurus janitor - Dechancé, 1964: 37 (Comoros, Bandéli, 1 ovigerous female $11 \mathrm{~mm}, \mathrm{MNHN}$; Pagurus janitor (Alcock, 1905) is a junior synonym of P. hirtimanus). - Pagurus hirtimanus (Figure 25 A-B) - Mayotte, KUW fieldwork November 2009, St. 5, Great north east reef, seagrass bed, $1 \mathrm{~m}, 1$ male Sl $7.1 \mathrm{~mm}$, Lc $13 \mathrm{~mm}$, Lt about $41 \mathrm{~mm}$, MNHN-Pg8538; St. 27, islet Mbouzi, 4-20 m, 1 male Sl 8.5 mm, Lt about 51 mm, MNHN-Pg8539; coll. J.-M. Bouchard, mli5-18, 1 male S1 $6 \mathrm{~mm}$, in shell, MNHN-Pg8540.

Distribution. - IWP. Red Sea, eastern Africa (Somalia), Madagascar, Mayotte (first record), Seychelles (Aldabra), Chagos, Indonesia, Malaysia, Japan, Mariana, Philippines, Papua New Guinea, Australia, New Caledonia, Fiji.

Remarks. - This species is characterized by a median line of spines on the outer face of the chela. In specimens examined from Mayotte in this study, this line is faint with spines minute or even reduced to tubercles. Despite this small difference, other characters and color pattern are in agreement with P. hirtimanus.

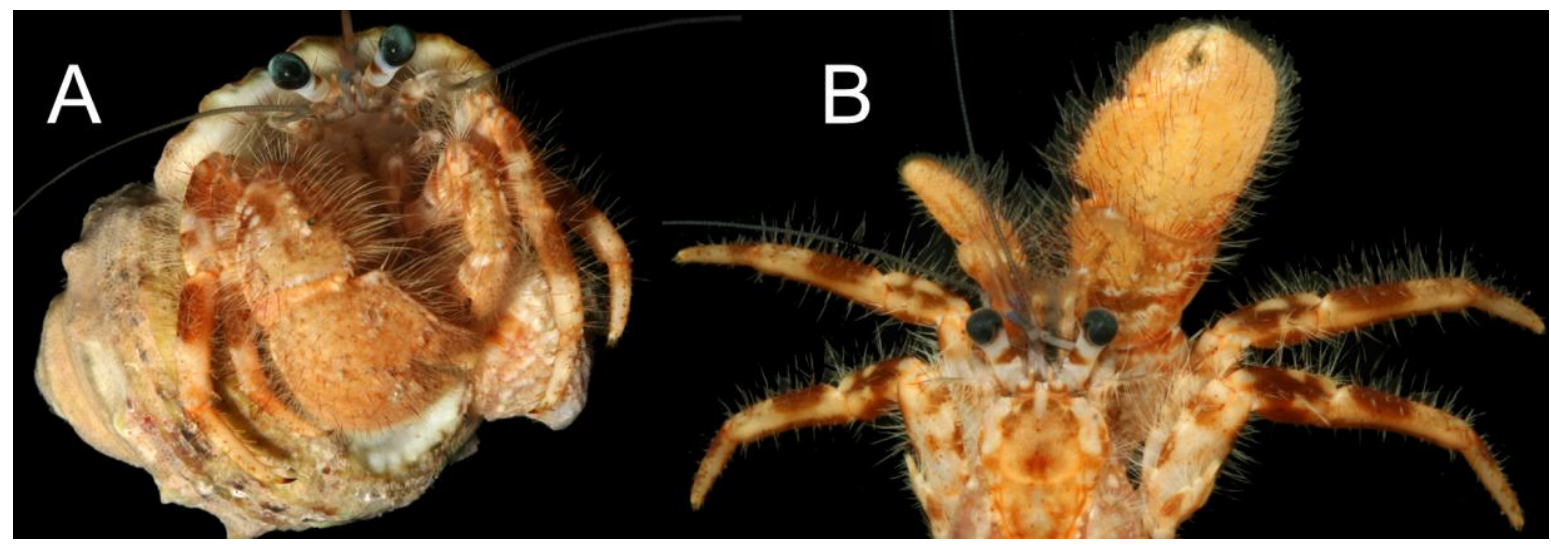

Figure 25. A-B) Pagurus hirtimanus, A) frontal view, 1 male S1 $7.1 \mathrm{~mm}$, Lc $13 \mathrm{~mm}$, Lt about $41 \mathrm{~mm}$, Mayotte, St. 5, MNHN-Pg8538; B) dorsal view, 1 male S1 $8.5 \mathrm{~mm}$, Lt about $51 \mathrm{~mm}$, Mayotte, St. 27, MNHN-Pg8539.

\section{Pylopaguropsis keijii McLaughlin \& Haig, 1989}

Pylopaguropsis keijii (Figure 26 A-C) - Mayotte, KUW fieldwork November 2009, St. 23, Choizil pass 'Patate à Teddy', 15-30 m, 1 male Sl $3.0 \mathrm{~mm}$, Lc $5 \mathrm{~mm}, \mathrm{Lt}$ about $22 \mathrm{~mm}$, as 'Pylopaguropsis lemaitrei' in Bouchard et al., 2009, photos p. 100, MNHN-Pg8536; St. 25, islet M'tzamboro, 15-20 m, 1 ovigerous female S1 1.9 mm, 1 female S1 2.6 mm, MNHN-Pg8537.

Distribution. - IWP. Eastern Africa (Zanzibar), Mayotte (first record), ?Réunion (see Remarks), Maldives, Japan, Caroline, Guam, Hawaii.

Remarks. - A medium-sized hermit crab, that can be easily recognized by shape of its larger chela and brilliant purple coloration of ambulatory legs and small (left) chela. According to descriptions in Asakura (2000) and Asakura \& Paulay (2003), these specimens from Mayotte can be attributed to Pylopaguropsis keijii based on well-marked longitudinal color stripes on ocular peduncles, as illustrated on figure $26 \mathrm{~B}$, and the presence of a single longitudinal groove (sulcus) on outer face of right P3 propodus. Pylopaguropsis lemaitrei Asakura \& Paulay, 2003 is a sibling species with overall coloration similar. It is known with certainty from its type locality (French Polynesia). In P. lemaitrei the longitudinal stripes on ocular peduncles are poorly marked and there are two longitudinal grooves on outer face of right $\mathrm{P} 3$ propodus. The record of $P$. lemaitrei from Réunion Island by Poupin (2009: photo p. 69) is from photograph, based on color pattern of ocular peduncle with only faint longitudinal color stripes. It should be confirmed by careful examination of the specimen (probably in UF) especially for the aspect of outer face of right $\mathrm{P} 3$ propodus, to confirm that it does not belong to P. keijii. 


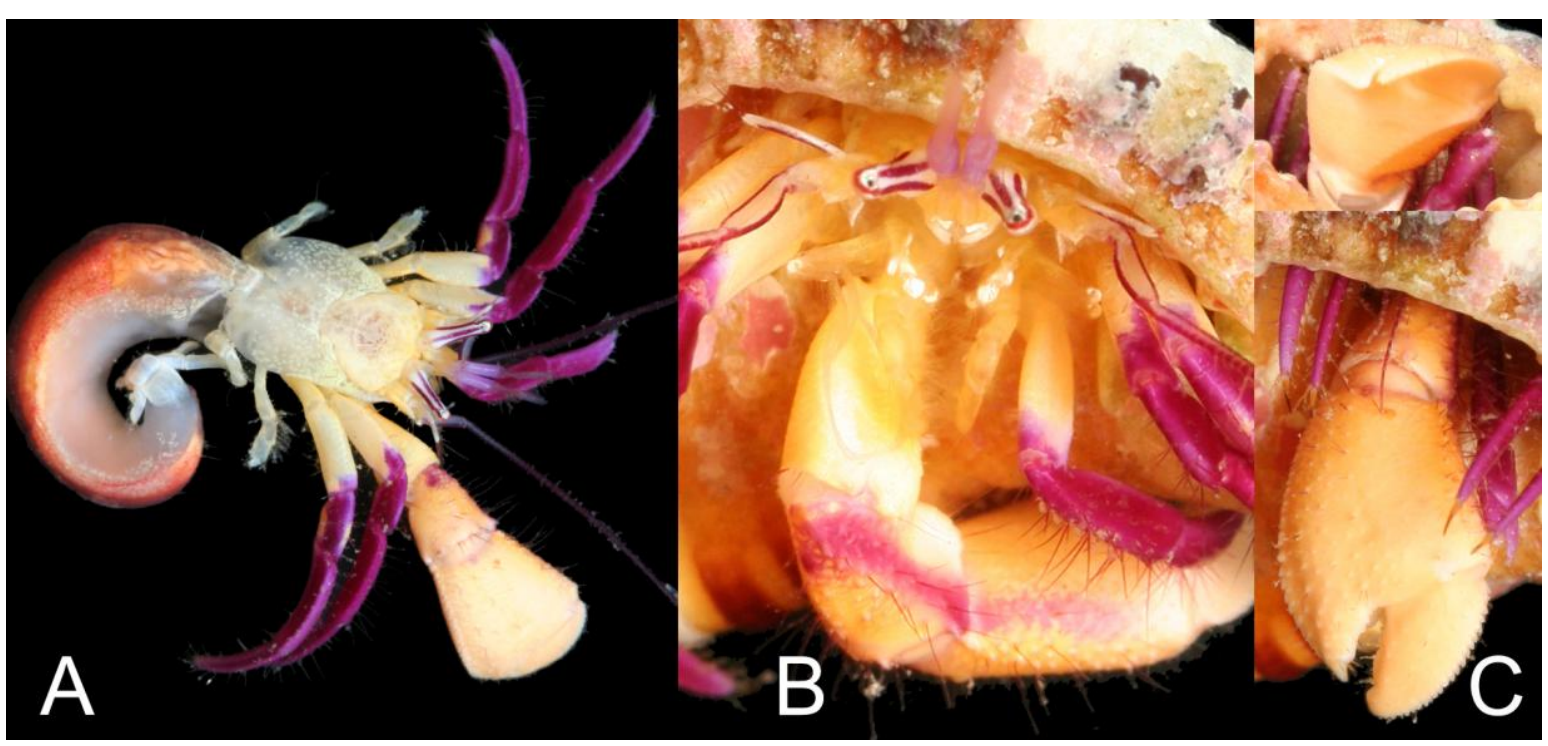

Figure 26. A-C) Pylopaguropsis keijii, 1 male Sl $3.0 \mathrm{~mm}$, Lc $5 \mathrm{~mm}$, Lt about $22 \mathrm{~mm}$, Mayotte, St. 23, MNHN-Pg8536, A) dorsal view, out of its shell, B) frontal view, C) frontal (top) and dorsal (bottom) aspect of larger chela.

\section{Trichopagurus trichophthalmus (Forest, 1954)}

Trichopagurus trichophthalmus - Mayotte, KUW fieldwork November 2009, St. 26, Mutsumbatsou reef flat, 1 ovigerous female S1 $1.2 \mathrm{~mm}$, MNHN-Pg8522.

Distribution. - IWP. Mayotte (first record), Maldives (Hogarth et al. 1998), Indonesia, Japan, Philippines (Sulu archipelago), Bikini, Palau, Ponape, French Polynesia.

Remarks. - Small-sized specimen, initially in the 'Paguridae spp.' lot. It has been correctly identified in June 2011 by T. Komai.

\section{FAMILY PARAPAGURIDAE}

Parapagurids are deep hermit crabs. Three species are currently reported from Mayotte region, all collected during the 1977 BENTHEDI campaign between 260-700 $\mathrm{m}$. They have a wide IWP geographic distribution. Two of them are illustrated here in color from photographs taken in French Polynesia.

\section{Paragiopagurus boletifer (de Saint Laurent, 1972)}

Sympagurus boletifer - Lemaitre, 1994: 382 (Mayotte, coll. BENTHEDI, 28 March 1977, St. 49F, Bovéni Passage, 300-450 m, 1 male S1 7.0 mm, 2 females S1 6.1 and $7.0 \mathrm{~mm}$, MNHN-Pg5138). - Paragiopagurus boletifer (Figure 27 A-C) - Lemaitre, 1996: 219 (New generic combination).

Distribution. - IWP. Mayotte, Japan, Australia, French Polynesia, Hawaii, Sala y Gòmez and Nazca seamounts. 85-800 m; 300-450 m in Mayotte region.

\section{Strobopagurus sibogae (de Saint Laurent, 1972)}

Strobopagurus sibogae - Lemaitre, 2004a: 369 (Glorioso, coll. BENTHEDI, 7 March 1977, St. 98F, 11³5.5'S, 47 $16.5^{\prime} \mathrm{E}, 260-460 \mathrm{~m}, 1$ female S1 $6.7 \mathrm{~mm}, \mathrm{MNHN}-\mathrm{Pg} 7132$ ).

Distribution. - IWP. Glorioso, Madagascar, Indonesia, Taiwan, China Sea, Japan, Philippines, New Caledonia, Solomon. 40-980 m; between 260-430 m in Mayotte region. 


\section{Sympagurus dofleini (Balss, 1912)}

Sympagurus dofleini (Figure 27 D) - Lemaitre, 2004b: 129 (Southeast Glorioso, coll. BENTHEDI, 12 April

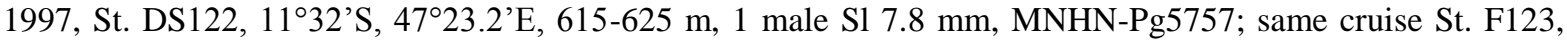

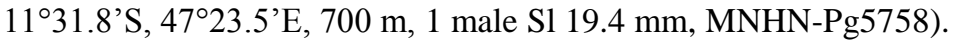

Distribution. - IWP. Eastern Africa (Zanzibar), Madagascar, Glorioso, Réunion, Indonesia, Japan, Mariana (Guam), New Caledonia, Wallis \& Futuna, Samoa, Tonga, French Polynesia, Hawaii, Sala y Gòmez and Nazca seamounts. 183-950 m; between 615-700 $\mathrm{m}$ in Mayotte region.

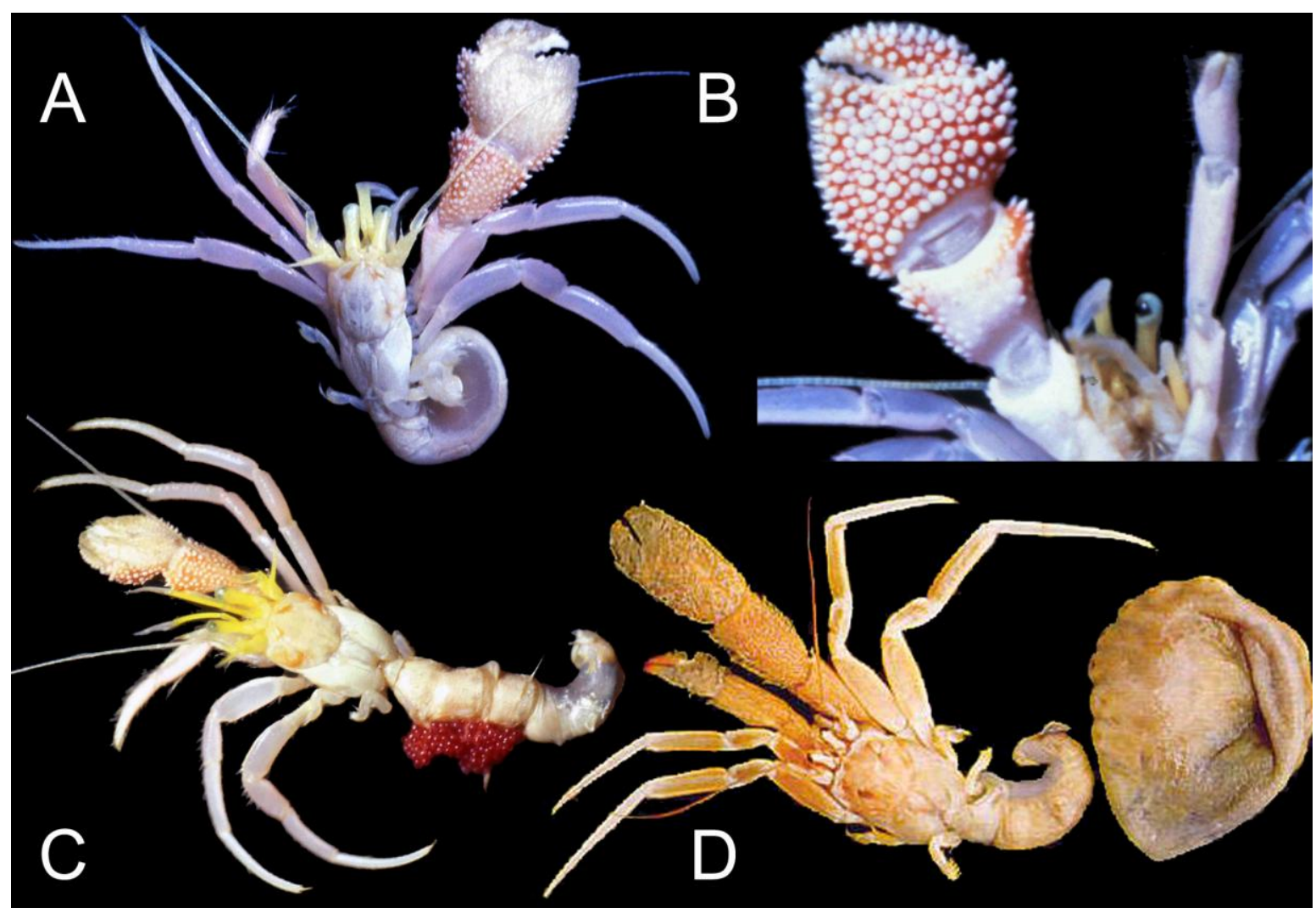

Figure 27. Parapaguridae from French Polynesia. A-C) Paragiopagurus boletifer, R/V Marara St. 344, 01 December 1990, 2353.3'S, 147³6.1'W, Autral Island, Raivavae trap at $350 \mathrm{~m}$; A) dorsal view; B) aspect of larger chela, ventral face, 1 male Sl $6 \mathrm{~mm}$, Lt about $30 \mathrm{~mm}$, MNHNPg5137; C) R/V Marara St. 437, 14 November 1994, 22²12.2'S, 13846.2'W, Tuamotu, Fangataufa atoll, trap $220 \mathrm{~m}, 1$ ovigerous female, Sl $7 \mathrm{~mm}$, MNHN (unnumbered). D)

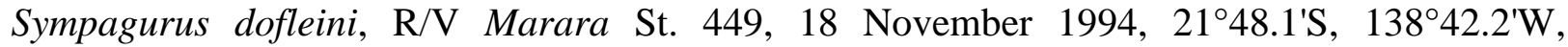
Tuamotu, Moruroa atoll, trap $600 \mathrm{~m}, 1$ specimen S1 $17 \mathrm{~mm}$, Lt about $116 \mathrm{~mm}$, with symbiotic actinian used to cover its abdomen, probably in MNHN.

\section{FAMILY PYLOCHELIDAE}

Pylochelids are also called 'symmetrical' hermit crabs because of a well developed abdomen with complete segmentation and paired appendages on each segment. They are deep hermit crabs that do not usually live in gastropod shells but dwell in stones, pieces of wood, tusk-shells, or living sponges. The three species reported here were collected during the 1977 BENTHEDI campaign, off Mayotte and Glorioso Islands, between 200-500 m. 


\section{Cheiroplatea stenurus Forest, 1987}

Cheiroplatea stenurus Forest, 1987a: 99, fig. 29, Mayotte, coll. BENTHEDI, St. DR38, 26 March 1977, 12 54.8'S, 45¹5.6'E, 200-500 m, holotype male S1 1.8 mm, MNHN-Pg3490; 1987b: 316, distribution and ethology. - McLaughlin \& Lemaitre, 2009: 176, re-examination of type specimen.

Distribution. - WIO. Mayotte. 200-500 m.

Remarks. - Living in a very eroded fragment of bryozoan.

\section{Pomatocheles stridulans Forest, 1987}

Pomatocheles stridulans Forest, 1987a: 127, fig. 37a-d, 38a, b, Mayotte, coll. BENTHEDI, 28 March 1977, St. F49, $12^{\circ} 54.6$ 'S, 4456.3'E, 300-450 m, holotype ovigerous female S1 2.2 mm, MNHN-Pg2899; 1987b: 315, distribution and ethology. - McLaughlin \& Lemaitre, 2009: 193, re-examination of type specimen.

Distribution. - WIO. Mayotte. 250-300 m, possibly to $450 \mathrm{~m}$. Habitat unknown.

\section{Trizocheles hoensonae McLaughlin \& Lemaitre, 2009}

Trizocheles balssi - Forest, 1987a: 196, Mayotte, coll. BENTHEDI, see material under McLaughlin \& Lemaitre (2009), not Trizocheles balssi (Stebbing, 1914). - Trizocheles hoensonae McLaughlin \& Lemaitre, 2009: 205, Mayotte, coll. BENTHEDI, 27 March 1977, St. DR41, 1305'S, 4505.5'E, 500-300 m, holotype male Sl 4.9 mm, MNHN-Pg3758. Paratypes: Mayotte, St. F54, 28 March 1977, 1301'S, 4455.3’E, 530 m, 1 male Sl 4.6

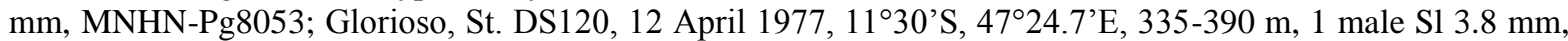

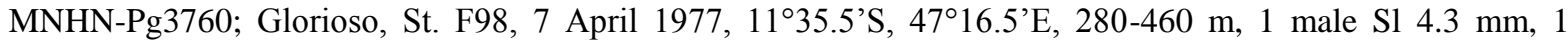
ovigerous female S1 4.2 mm, MNHN-Pg3759.

Distribution. - WIO. Mayotte and Glorioso only. Not Réunion as indicated by error in McLaughlin \& Lemaitre (2009 : 208) (pers. com. P.A. McLaughlin). 280-530 m. Habitat unknown.

\section{DISCUSSION}

\section{SPECIES RICHNESS}

The number of species by family is presented in Table 1. Overall, 75 species are recorded: $68 \%$ in the Paguroidea, $29.4 \%$ in the Galatheoidea, $1.3 \%$ in Chirostyloidea and $1.3 \%$ in the Hippoidea. There is a predominance of the Diogenidae (29 species), Porcellanidae (13 species), Paguridae (11 species) and Galatheidae (7 species). In comparison the number of species of Anomura is 62 in la Réunion, 349 in New Caledonia, and 186 in French Polynesia (Poupin, 2010).

Considering the Complementary List herein included, and the 3 species presented in 'Paguridae spp.', at least 129 anomurans species could be present in Mayotte region. A few taxa are, however, insufficiently sampled in the area, such as the Hippoidea, Diogenidae, and Porcellanidae.

\section{SPATIAL ANALYSIS \\ VERTICAL DISTRIBUTION}

The vertical distribution of the species is indicated in appendix 2 (table 2) with distinction of four vertical ranges: supra-tidal, intertidal, shallow waters $(0-60 \mathrm{~m})$, deep sea $(60$ to +1000 $\mathrm{m})$. 
The supra-tidal range includes the five coenobitids leaving in the upper part of intertidal area and already listed with the land species in Bouchard et al. (2011). Two of them (Coenobita perlatus and $C$. rugosus) are also common in the intertidal area. Clibanarius longitarsus is also present in the supra-tidal area. It is an ubiquitous species, observed in Mayotte in mangroves (e.g. Kangani mangrove at St. 2) and in the tide pools of the intertidal, at low tide (e.g. Badamiers spillway at St. 6).

Twenty eight anomurans are found in the intertidal area, including 21 species collected at low tide under rocks or in tide pools during our study, and seven additional species that are potentially present in that range according to the literature. Four species are very common in Mayotte: Calcinus laevimanus, C. latens, Clibanarius virescens, and Petrolisthes lamarckii.

Table 1 - Anomura of Mayotte region, with number of species (n) by families and superfamilies. Right column is an estimate of number of species potentially present in the area, based on the Complementary List.

\begin{tabular}{|c|c|c|c|}
\hline Superfamily & Family & $n$ & Potential \\
\hline \multirow[t]{2}{*}{ Chirostyloidea (1.5\%) } & & 1 & 2 \\
\hline & Eumunididae & 1 & 2 \\
\hline \multirow[t]{5}{*}{ Galatheoidea (30 \%) } & & 22 & 40 \\
\hline & Galatheidae & 7 & 11 \\
\hline & Munididae & 2 & 4 \\
\hline & Munidopsidae & & 2 \\
\hline & Porcellanidae & 13 & 23 \\
\hline \multirow[t]{3}{*}{ Hippoidea (1.5 \%) } & & 1 & 7 \\
\hline & Albuneidae & & 4 \\
\hline & Hippidae & 1 & 3 \\
\hline \multirow[t]{6}{*}{ Paguroidea (67 \%) } & & 51 & 80 \\
\hline & Coenobitidae & 5 & 5 \\
\hline & Diogenidae & 29 & 45 \\
\hline & Paguridae & 11 & 19 \\
\hline & Parapaguridae & 3 & 8 \\
\hline & Pylochelidae & 3 & 3 \\
\hline Total (100 \%) & & 75 & 129 \\
\hline
\end{tabular}

The majority of the species (47 species, i.e. 63\%) were collected in the shallow waters of the lagoon or along the outer reef slope during dives made between 1-62 $\mathrm{m}$ with most of the operations taking place between 5-25 m. The anomurans living in these depth zones can be arbitrarily classified in three main groups according to their body size. 
Large-sized hermits include three species of Aniculus, seven Dardanus, and Pagurus hirtimanus. These are commonly observed wandering on the sea floor and can be often determined in situ based on their distinctive color patterns (Figs 3, 13, 20, 21, 25).

Twenty four hermit crabs of this deep range are of medium-small size. These include all Galatheidae and Munididae, the Porcellanidae Neopetrolisthes maculatus and Pachycheles sculptus, the Diogenidae Areopaguristes abbreviatus, Calcinus spp., Ciliopagurus tricolor, Clibanarius spp., Diogenes pallescens, and the Paguridae Pagurixus rubrovittatus, Pagurixus nomurai, and Pylopaguropsis keijii. Most of them can still be recognized in situ during a dive.

Twelve species of this deep range are of very small size, with maximum length usually of about only 3-10 $\mathrm{mm}$. They usually cannot be recognized confidently in situ and must be determined with a stereomicroscope. They have been collected by brushing on coral blocks or with suction pump on debris and fine coral sands. These are the Porcellanidae Aliaporcellana pygmaea, Polyonyx spp., and the Paguridae Anapagrides reesei, Pagurixus carinimanus, $P$. patiae, P. purpureus, P. ruber, P. rubrovittatus, and Trichopagurus trichophthalmus.

\section{GEOGRAPHIC DISTRIBUTION}

The anomuran fauna of Mayotte region is predominantly IWP in its composition with $84 \%$ of the species distributed in the IWP. Only twelve species (Table 2) are distributed exclusively in WIO. Petrolisthes rufescens is from IO, common in WIO but reaching Nicobar Islands to the East. Five species, including the three deep pylochelids, are known only from the Mayotte region: Cheiroplatea stenurus, Galathea denticulata, Polyonyx aff. boucheti, Pomatocheles stridulans, and Trizocheles hoensonae.

\section{COMPLEMENTARY LIST}

A literature search was made to find additional records of species potentially present in the Mayotte region. The species in the Complementary List are based on this search, and are still not known in the Mayotte region but have a wide IWP distribution and/or have been reported at the same time from the African eastern coast and the Seychelles, or Madagascar and the Seychelles. Excluded from this List include those present in the Seychelles but not further west in WIO, or those known only from the eastern African coast. 
The studies consulted for the search are: Laurie (1926), Baba et al. (2008), Macpherson \& Cleva (2010), for Chirostylidae, Galatheidae, Munididae, and Munidopsidae; Laurie (1926), Kensley (1970), Lewinsohn (1979), and Haig (1966, 1983), for the Porcellanidae; Thomassin (1969), Serène (1977), Boyko \& Harvey (1999), and Boyko (2002), for the Hippoidea; Laurie (1926), Derijard (1966), Dechancé (1964), Reay \& Haig (1990), Lewinsohn (1982), Gherardi \& McLaughlin (1994), Hogarth et al. (1998), McLaughlin (2004), McLaughlin \& Hogarth (1998), Rahayu (2007), for the Diogenidae, and the Paguridae; Lemaitre (2004a, b), for the Parapaguridae; and McLaughlin \& Lemaitre (2009), for the Pylochelidae.

\section{Complementary list (with western and eastern boundaries and depth ranges)}

\section{Chirostylidae}

Uroptychus nigricapillis Alcock, 1901 - IWP: Kenya, Madagascar to Saya de Malha, Maldives, Japan. 66-2000 m.

\section{Galatheidae}

Allogalathea elegans (Adams \& White, 1848) - IWP: Red Sea, Mozambique, Madagascar, Seychelles to Fiji. $1-183 \mathrm{~m}$.

Galathea ternatensis De Man, 1902 - IWP: Madagascar, Seychelles to New Caledonia. 18-210 m.

Lauriea gardineri (Laurie, 1926) - IWP: Red Sea, off Somalia, Madagascar, Seychelles to New Caledonia. 6-382 m.

Phylladiorhynchus integrirostris (Dana, 1852) - IWP: Off Somalia, South Africa, Madagascar, Seychelles to French Polynesia. 0-160 m.

\section{Munididae}

Munida barbeti Galil, 1999 - WIO: Madagascar, Réunion, Aldabra. 28-115 m.

Paramunida tricarinata (Alcock, 1894) - IWP: Zanzibar, Madagascar, Seychelles to Maldives, Taiwan. 205-457 m.

\section{Munidopsidae}

Leiogalathea laevirostris (Balss, 1913) - IWP: Madagascar, Seychelles to Japan, French Polynesia. 160-812 m.

Munidopsis serricornis (Lovén, 1852) - Worldwide, Atlantic and IP: Madagascar, Saya de Malha to Indonesia, Australia, Taiwan, Philippines. 96-2091 m.

\section{Porcellanidae}

Enosteoides melissa (Miyake, 1942) - IWP: Zanzibar, Madagascar, Seychelles to Loyalty Islands. 0-110 m.

Lissoporcellana quadrilobata (Miers, 1884) - IWP: Mozambique, Madagascar, Seychelles to Loyalty Islands. 0-128 m.

Neopetrolisthes alobatus (Laurie, 1926) - WIO: Mozambique, Cargados Carajos. Subtidal.

Pachycheles garciaensis (Ward, 1942) - WIO: Europa, Madagascar, Réunion, Chagos. Intertidal.

Pachycheles pisoides (Heller, 1865) - IWP: Madagascar, Seychelles, to Hawaii, French Polynesia. InterSubtidal.

Pachycheles natalensis (Krauss, 1843) - WIO: Red Sea to South Africa, Madagascar to India. Intertidal. Petrolisthes coccineus (Owen, 1839) - IWP: Mozambique, Seychelles to Hawaii, French Polynesia. Intertidal. Petrolisthes militaris (Heller, 1862) - IWP: Mozambique, Madagascar, Seychelles to New Caledonia. 0-180 m. Petrolisthes moluccensis (De Man, 1888) - IWP: Somalia, Seychelles to Japan, Palau. Inter-Subtidal. 


\section{Albuneidae}

Albunea elioti Benedict, 1904 - IWP: Madagascar, Seychelles to Japan, Fiji, Tonga, Samoa. Subtidal-32 m. Albunea holthuisi Boyko \& Harvey, 1999 - IWP: Tanzania, Madagascar, Indonesia. Subtidal-34 m. Albunea microps Miers, 1878 - IWP: Tanzania, Seychelles, Maldives to Indonesia, Philippines. 3-45 m. Albunea speciosa Dana, 1852 - IWP: Madagascar, Seychelles, Réunion, Maldives to Japan Hawaii, French Polynesia. 3-34 m.

\section{Hippidae}

Hippa marmorata (Hombron \& Jacquinot, 1846) - IP: Tanzania, Madagascar to Hawaii, French Polynesia, East Pacific. Intertidal.

Hippa ovalis (A. Milne-Edwards, 1862) - IWP: East coast of Africa, Réunion to Papua New Guinea, French Polynesia. Intertidal.

\section{Diogenidae}

Calcinus guamensis Wooster, 1984 - IWP: Somalia, Réunion, Christmas \& Cocos, Indonesia, Vietnam to Japan, Mariana, Hawaii, French Polynesia. Subtidal to $30 \mathrm{~m}$.

Calcinus seurati Forest, 1951 - IWP: Somalia, Christmas \& Cocos to Japan, Hawaii, French Polynesia. Intertidal.

Calcinus tropidomanus Lewinsohn, 1981. WIO: Somalia, Seychelles. Intertidal-Subtidal.

Ciliopagurus shebae (Lewinsohn, 1969) - IWP: Red Sea, Madagascar, Seychelles to Japan. 20-130 m.

Clibanarius merguiensis De Man, 1888 - IWP: Kenya, Madagascar, Mauritius to Indonesia, New Caledonia, ?Wallis \& Futuna. Intertidal-Subtidal.

Clibanarius striolatus Dana, 1852 - IWP: Kenya, Madagascar, Seychelles to Japan, French Polynesia. Intertidal-Subtidal.

Dardanus brachyops Forest, 1963 - IWP: Madagascar to Hawaii and French Polynesia. 80-300 m.

Dardanus setifer (H. Milne Edwards, 1836) - IWP: South Africa, Madagascar, Seychelles to Taiwan, New Caledonia. Subtidal.

Dardanus tinctor (Forskål, 1775). WIO: Red Sea, Tanzania, Europa, Mauritius. Subtidal.

Diogenes avarus Heller, 1865 - IWP: Tanzania, Mozambique, Seychelles, Red Sea to Philippines. Intertidal-38 m.

Diogenes costatus Henderson, 1893 - IO: Kenya, Mozambique, Seychelles. Intertidal.

Diogenes leptocerus Forest, 1957 - IWP: Somalia, Vietnam. Intertidal.

Paguristes antennarius Rahayu, 2006 - IWP - Madagascar, Indonesia. 425-720 m.

Paguristes lauriei McLaughlin \& Hogarth, 1998. - WIO - Seychelles, Réunion. 40-225 m.

Paguristes puniceus Henderson, 1896 - IWP: Madagascar, Réunion, India, Indonesia, Australia. 150-776 m.

Pagurixus anceps (Forest, 1954). - IWP: Red Sea, Somalia, Maldives to Philippines, French Polynesia. Shallow subtidal.

\section{Paguridae}

Catapagurus ensifer Henderson, 1893 - IWP: Red Sea, Seychelles to Indonesia, French Polynesia. Subtidal to $54 \mathrm{~m}$.

Nematopagurus diadema Lewinsohn, 1969 - IWP: Red Sea, South Africa to Indonesia, China, New Caledonia, Fiji. 62-295 m.

Nematopagurus gardineri Alcock, 1905 - IWP: South Africa, Seychelles to Japan, New Caledonia. 18-99 m.

Nematopagurus spinulosensoris McLaughlin \& Brock, 1974 - IWP: South Africa, Madagascar, Seychelles to Hawaii, French Polynesia. 110-540 m.

Pagurixus anceps (Forest, 1954) - IWP: Somalia, Red Sea to Japan, Mariana, French Polynesia. Subtidal. 


\section{Parapaguridae}

Sympagurus affinis (Henderson, 1888) - IWP: Madagascar to Indonesia, Australia, Japan, Philippines, Hawaii, French Polynesia, Nazca and Sala y Gómez ridges. 147-1450 m.

Sympagurus andersoni (Henderson, 1896) - IO: Somalia to Mozambique, Madagascar, Seychelles to Maldives, Laccadives, Straits of Malacca. 80-1840 m.

Sympagurus brevipes (de Saint Laurent, 1972) - IWP: Zanzibar, Madagascar, Réunion to Indonesia, Philippines, New Caledonia, Vanuatu. 210-1300 m.

Sympagurus burkenroadi Thompson, 1943 - IWP: Zanzibar, Mozambique, Madagascar to Indonesia, Australia, Japan, New Caledonia. 205-1120 m.

Sympagurus trispinosus (Balss, 1911) - IWP: South Africa, Zanzibar, Madagascar, Réunion to Indonesia, Australia, Philippine, New Caledonia, French Polynesia. 350-1500 m.

\section{ASSOCIATIONS}

Associations of the anomurans of Mayotte with other coral reef organisms are still poorly known. Only a few associations are listed based on field observations and collection data.

Anemone associates: the porcellanid Neopetrolisthes maculatus is always associated with a giant sea anemone of the genera Cryptodendrum, Entacmaea, or Stichodactyla. Two Dardanus, D. deformis and D. gemmatus, always carry a sea-anemone (genus Calliactis) on the shell used to shelter their abdomens. In deep waters, Sympagurus dofleini also lives in association with a sea-anemone (Epizoanthus) that is used to shelter the abdomen, perhaps because of the difficulty to find mollusk shell at these depths.

Sponge associate: the porcellanid Aliaporcellana pygmaea is reported as collected 'on bottoms of sand ... among sponges and antipatharians' by Haig (1983: 285). The species was collected on similar bottoms during this study.

Coral associates: a lot of species have been collected among broken coral or coral rubbles and are probably obligatory or facultative coral associates although the intimate nature of the association could not be observed. Species associated with corals include: Galathea spp., Macrothea bouchardi, Sadayoshia edwardsii, Calcinus morgani, C. aff. pulcher, C. rosaceus, C. vachoni, and Pagurixus spp. 


\section{CONCLUSION AND PROSPECTS}

In total 75 Anomura are recorded in the Mayotte region. All specimens that were collected during the KUW 2009 fieldwork are deposited in MNHN, where they are available for further systematic studies. Three additional small-sized species have been treated apart: Cestopagurus caeruleus, Trichopagurus asper (Komai \& Poupin, 2012), and Polyonyx aff. boucheti (Poupin, forthcoming). Two small-sized specimens of Micropagurus aff. polynesiensis (Nobili, 1906) are also awaiting a revision while more specimens are available from the IWP (Komai, forthcoming).

The deep specimens collected on the Leven Bank during the 2009 MIRIKY cruise are also deposited in MNHN. Only two species of this cruise are reported in this compilation (Eumunida sp., and Munida sp., Fig. 5 C-D), the others specimens being still unstudied at present. In the future, potential new records will thus probably be reported for the Mayotte region based on this unstudied collection.

Other Anomura collected in the Mayotte region (Mayotte, Glorioso) that are still unstudied are deposited in UF. This collection has been made in 2008/2009 during the BIOTAS program. Twenty two common species from this collection are included herein, based only on examination of color photographs.

To complete this compilation, review of the literature indicates that at least 129 Anomura could be found in the Mayotte region with three groups in need of better sampling when future fieldworks are organized in the area, the Hippoidea, the Diogenidae, and the Porcellanidae.

\section{ACKNOWLEDGMENTS}

Financial support for this study has been obtained from the Direction de l'Agriculture et de la Forêt of Mayotte (DAF) and Total Foundation. Supplementary assistance for this research has been given by the Institut de Recherche de l'Ecole Navale, Brest (IRENav) and the Muséum national d'Histoire naturelle, Paris (MNHN). A few photographs have been obtained through the courtesy of collaborators cited here by alphabetical order: Marc Allaria, Alain Barrère, Laurent Bêche, Philippe Bouchet, Laure Corbari, Matthias Deuss, Mathieu Foulquié, François Fromard, Peter Hogarth, Chia-Wei Lin, BIOTAS team courtesy Machel Malay, Benjamin Pineau, Gustav Paulay, Sonia Ribes. Rafael Lemaitre has accepted to review the manuscript. 


\section{LITERATURE CITED}

Ahyong S. T., Baba K., Macpherson E. and G. C. B. Poore

2010. A new classification of the Galatheoidea (Crustacea: Decapoda: Anomura). Zootaxa, 2676: $57-68$.

At http://decapoda.nhm.org/pdfs/31612/31612.pdf

Asakura A.

2000. A review of Japanese species of Pylopaguropsis Alcock, 1905 (Decapoda: Anomura: Paguridae). Crustacean Research, 29: 70-108.

At http://ci.nii.ac.jp/lognavi?name=nels\&lang=en\&type=pdf\&id=ART0002970366

Asakura A. and G. Paulay

2003. Pylopaguropsis lemaitrei, a new species of hermit crab (Decapoda: Anomura: Paguridae) from French Polynesia. Crustacean Research, 32: 13-25.

At http://ci.nii.ac.jp/lognavi?name=nels\&lang=en\&type=pdf\&id=ART0002970412

Asakura A. and H. Tachikawa

2004. Boninpagurus acanthocheles, a new genus and species of hermit crab (Decapoda, Anomura, Paguridae) from shallow waters of the Ogasawara (Bonin) Islands, Japan. Journal of Crustacean Biology, 24(1): 157-167.

Baba K.

1990. Chirostylid and Galatheid Crustaceans of Madagascar (Decapoda Anomura). Bulletin du Muséum national d'Histoire naturelle, Paris, 4ème série A, 1989 (1990), 11: 921-975. At http://decapoda.nhm.org/pdfs/29335/29335.pdf

Baba K., Macpherson E. Poore C. B., Ahyong S. T., Bermudez A., Cabezas P., Lin C.-W., Nizinski M., Rodrigues C. and Schnabel K. E.

2008. Catalogue of squat lobsters of the world (Crustacea: Decapoda: Anomura - families Chirostylidae, Galatheidae and Kiwaidae). Zootaxa, 1905: 1-220.

At http://decapoda.nhm.org/pdfs/28230/28230.pdf

Bouchard J.-M., Poupin J., Cleva R., Dumas J. and V. Dinhut

2009. Rapport de mission du 2 au 22 novembre. Mission Crustacés Mayotte 2009. Rapport Kraken Underwater Works, KUW, Mamoudzou, Mayotte: 151 pp.

At http://crustaceamayotte.free.fr/

2011. Land, mangrove and freshwater decapod crustaceans of Mayotte region (Crustacea, Decapoda). Atoll Research Bulletin, accepted April 2011: 1-69.

At http://www.sil.si.edu/digitalcollections/atollresearchbulletin/

Boyko C. B.

2002. A worldwide revision of the recent and fossil sand crabs of the Albuneidae Stimpson and Blepharipodidae, new family (Crustacea: Decapoda: Anomura: Hippoidea). Bulletin of the American Museum of Natural History, 272: 1-396.

Boyko C. B. and A. W. Harvey

1999. Crustacea Decapoda: Albuneidae and Hippidae of the tropical Indo-West Pacific region. In: A. Crosnier (ed.), Résultats des campagnes MUSORSTOM, Volume 20. Mémoires du Muséum national d'Histoire naturelle, 180: 379-406. 
Boyko C. B. and P. A. McLaughlin

2010. Annotated checklist of anomuran decapod crustaceans of the world (exclusive of the Kiwaoidea and families Chirostylidae and Galatheidae of the Galatheoidea) Part IV Hippoidea. The Raffles Bulletin of Zoology, supplement 23: 139-151.

At http://rmbr.nus.edu.sg/rbz/supplement23.html

Bruce A. J.

1967. Notes on some indo-pacific Pontoniinae III-IX. Descriptions of some new genera and species from the Western Indian Ocean and the South China Sea. Zoologische Verhandelingen, 87: 1-73.

At http://www.repository.naturalis.nl/document/148937

1971. Pontoniinid shrimps from the ninth cruise of R/V Anton Bruun, IIOE, 1964: I. Palaemonella Dana and Periclimenes Costa. Smithsonian Contributions to Zoology, 82: 1-13.

At http://hdl.handle.net/10088/5302

Coppinger R. W.

1884. Cruise of the Alert Four years in Patagonian, Polynesian, and Mascarene Waters (1878-82). R. Worthington, 770 Broadway, New York, Second Edition: 1-256. At http://www.biodiversitylibrary.org/item/73428

Dana J. D.

1855. Crustacea. Atlas 13: 1-27, pl. 1-96.

At http://www.sil.si.edu/imagegalaxy/imageGalaxy_MoreImages.cfm?book_id=19-21

Daniel J., Dupont J. and C. Jouannic

1972. Géologie sous-marine - Relations Madagascar - Archipel des Comores (Nord-est du canal de Mozambique). Sur la nature volcanique du Banc du Leven. Comptes Rendus de l'Académie des Sciences, Paris, 274: 1784-1787.

At http://horizon.documentation.ird.fr/exl-doc/pleins_textes/pleins textes_5/b_fdi_04-05/05432.pdf

Dechancé M.

1963. Sur des Paguristes littoraux de l'ouest de l'océan Indien: $P$. jousseaumei Bouvier, $P$. perspicax Nobili et $P$. abbreviatus sp. nov. (Crustacea Decapoda Paguridea). Bulletin du Muséum national d'Histoire naturelle, 35: 291-301.

1964. Sur une collection de crustacés pagurides de Madagascar et des Comores. Cahiers de l'ORSTOM, II(2): 27-45.

At http://horizon.documentation.ird.fr/exl-doc/pleins_textes/cahiers/oceanographie/19448.pdf

Derijard R.

1966. Note préliminaire sur les crustacés stomatopodes et décapodes récoltés a l'île Europa du 6 au 24 Avril 1964. Mémoire du Muséum national d'Histoire naturelle, 4(41): 159-180.

Forest J.

1953. Crustacés Décapodes marcheurs des îles de Tahiti et des Tuamotu. I. Paguridea. Bulletin du Muséum national d'Histoire naturelle, 25(5): 441-450.

1957. Les Pagures du Viêt-Nam. I - Le genre Diogenes Dana. Bulletin du Muséum du Muséum national d'Histoire naturelle, 1956 (1957), 28(6): 524-532.

1984. Révision du genre Aniculus Decapoda Diogenidae. Crustaceana, supplement, 8: 1-91. 
1987a. Les Pylochelidae ou "Pagures symétriques" (Crustacea Coenobitoidea). In: A. Crosnier (ed.), Résultats des campagnes MUSORSTOM, Volume 3. Mémoires du Muséum national d'Histoire naturelle, 137: 1-254, pl. 1-9.

1987b. Ethology and distribution of Pylochelidae (Crustacea Decapoda Coenobitidae). Bulletin of Marine Science, 41(2): 309-321.

At http://www.ingentaconnect.com/content/umrsmas/bullmar/1987/00000041/00000002/art00019

Fourmanoir P.

1955. Crustacés Macroures et Anomoures, Stomatopodes. Notes sur la faune intercotidale des Comores. Le Naturaliste Malgache, 7(1): 19-33.

At http://horizon.documentation.ird.fr/exl-doc/pleins textes/pleins textes 5/b_fdi_10-11/11450.pdf

Gherardi F. and P. A. McLaughlin

1994. Shallow-water hermit crabs (Crustacea: Decapoda: Anomura: Paguridae) from Mauritius and Rodrigues islands, with the description of a new species of Calcinus. Raffles Bulletin of Zoology, 42(3): 613-656.

At http://rmbr.nus.edu.sg/rbz/journal423.html

Guilcher A., Berthois L., Le Calvez Y., Battistini R. and A. Crosnier

1965. Les récifs coralliens et le lagon de l'île de Mayotte (Archipel des Comores, Océan Indien), Géomorphologie, Sédimentologie, Hydrologie, Foraminifères. Office de la Recherche Scientifique et Technique Outre-Mer. ORSTOM Ed., Paris, 210 pp. At http://horizon.documentation.ird.fr/exl-doc/pleins_textes/pleins textes_2/memoires/10967.pdf

Haig J.

1966. Sur une collection de crustacés porcellanes (Anomura: Porcellanidae) de Madagascar et des Comores. Cahiers de l'ORSTOM, 1965 (1966), 3(4): 39-50.

At http://horizon.documentation.ird.fr/exl-doc/pleins textes/cahiers/oceanographie/19487.pdf

1983. Porcellanidae (Decapoda, Anomura) from the Seychelles, western Indian Ocean. Crustaceana, 45(3): 279-289.

Haig J. and E. E. Ball

1988. Hermit crabs from north Australian and eastern Indonesian waters (Crustacea Decapoda: Anomura: Paguroidea) collected during the 1975 Alpha Helix Expedition. Records of the Australian Museum, 40(3): 151-196.

At http://australianmuseum.net.au/journal/Haig-and-Ball-1988-Rec-Aust-Mus-403-151196

Haig J. and R. K. Kropp

1987. Petrolisthes eldredgei, a new porcellanid crab from the indo-west Pacific, with redescription of two related species. Micronesica, 20: 171-186.

Hoffmann C. K.

1874. Crustacés et Echinodermes de Madagascar et de l'île de la Réunion. In: F. P. L. Pollen et D. C. Van Dam, Recherches sur la Faune de Madagascar et de ses dépendances, 5 ème partie. Leiden, E. J. Brill: 1-58, pl. 1-10.

At http://www.biodiversitylibrary.org/item/99944\#page/43/mode/1up

Hogarth P. J., Gherardi F. and P. A. McLaughlin

1998. Hermit crabs of the Maldives, with the description of a new species of Catapagurus. Tropical Zoology, 11: 149-175. 
Jones D. and G. Morgan

2002. A field guide to the crustaceans of Australian waters. Reed, Western Australian Museum Book (second edition), 224 pp.

Kensley B.

1970. A small collection of decapod Crustacea from Mozambique. Annals of South African Museum, 57 (5): 103-122.

Komai T.

2004. Calcinus areolatus Rahayu \& Forest, an invalid taxon founded on juvenile or young stages of Calcinus morgani Rahayu \& Forest (Crustacea: Decapoda: Anomura: Diogenidae). Biological Magazine, 42: 25-38.

2010. New species and new records of the hermit crab genus Pagurixus Melin, 1939 (Crustacea: Decapoda: Anomura: Paguridae) from the Indo-West Pacific. Journal of Natural History 44 (21): 1269-1342.

Komai T. and M. Osawa

2006. A review of the Pagurixus boninensis species group, with descriptions of six new species (Crustacea: Decapoda: Anomura: Paguridae). Zootaxa, 1214: 1-107.

Komai T. and J. Okuno

2009. Two New Species of the Hermit Crab Genus Pagurixus (Decapoda: Anomura: Paguridae) from the Western Pacific. Bulletin National Museum Natural Sciences, Supplement, 3: 137-156.

Komai T. and J. Poupin

2012. Two new species of shallow-water hermit crabs (Crustacea: Decapoda: Paguridae) from Mayotte Island, southwestern Indian Ocean. Zootaxa, 3277: 56-68.

Kornicker L.

1992. Myodocopid Ostracoda of the BENTHEDI Expedition, 1977, to the NE Mozambique Channel, Indian Ocean. Smithsonian Contribution to Zoology, 531: 1-243.

At http://hdl.handle.net/10088/5571

Kropp R. K.

1986. A neotype designation for Petrolisthes tomentosus (Dana), and description of Petrolisthes heterochrous, new species, from the Mariana islands (Anomura: Porcellanidae). Proceeding of the Biological Society of Washington, 99(3): 452-463.

Laurie R. D.

1926. Reports of the Percy Sladen Trust Expedition to the Indian Ocean in 1905, under the leadership of Mr. J. Stanley Gardiner, M.A. Vol. 8, No. VI. Anomura collected by Mr. J. Stanley Gardiner in the western Indian Ocean in H.M.S. Sealark. Transactions of the Zoological Society of London, 19: 121-167.

Lemaitre R.

1994. Crustacea Decapoda: Deep-water hermit crabs (Parapaguridae) from French Polynesia with description of four new species. In: A. Crosnier (ed.), Résultats des campagnes MUSORSTOM, Volume 12, Mémoires du Muséum National d'Histoire naturelle, 161: 375-419.

1996. Hermit crabs of the family Parapaguridae (Crustacea: Decapoda: Anomura) from Australia: species of Strobopagurus Lemaitre, 1989, Sympagurus Smith, 1883 and two new genera. Records of the Australian Museum, 48: 163-221.

At http://publications.australianmuseum.net.au/record.cfm?ref=286 
2004a A review of Strobopagurus Lemaitre, 1989 (Crustacea: Decapoda: Paguroidea: Parapaguridae), with description of a new species. Scientia Marina, 68(3): 355-372. At http://www.icm.csic.es/scimar/index.php/secId/6/IdArt/3156/

2004b A worldwide review of hermit crab species of the genus Sympagurus Smith, 1883 (Crustacea: Decapoda: Parapaguridae). In: Marshall B. \& B. Richer de Forges (eds), Tropical Deep-sea Benthos, volume 23. Mémoires du Muséum national d'Histoire naturelle, 191: 85-149.

Lewinsohn C.

1979. Researches on the coast of Somalia. The shore and the dune of Sar Uanle. 23. Porcellanidae (Crustacea Decapoda Anomura). Monitore Zoologico Italiano, supplemento, 12(6): 39-57, pl. 1.

1982. Researches on the coast of Somalia. The shore and the dune of Sar Uanle. 33 Diogenidae, Paguridae and Coenobitidae (Crustacea Decapoda Paguridae). Monitore Zoologico Italiano, supplemento, 16(2): 35-68.

Low M. E. Y. and S. H. Tan (eds)

2010. Checklists of anomuran decapod crustaceans of the world (exclusive of the Kiwaoidea and families Chirostylidae and Galatheidae of the Galatheoidea) and marine lobsters of the world. The Raffles Bulletin of Zoology, supplement 23: i-iii.

At http://rmbr.nus.edu.sg/rbz/supplement23.html

Macpherson E. and K. Baba

2010. Revision of the genus Sadayoshia (Anomura, Galatheidae), with description of four new species. In: Fransen C. H. J. M., De Grave S. and P. K. L. Ng (eds.) Studies on Malacostraca: Lipke Bijdeley Holthuis Memorial Volume. Crustaceana Monographs. Fransen C. H. J. M. and J. C. von Vaupel Klein (series eds.) Leiden, Brill, 14: 415-452. At http://decapoda.nhm.org/pdfs/31634/31634.pdf

Macpherson E. and R. Cleva

2010. Shallow-water squat lobsters (Crustacea, Decapoda, Galatheidae) from Mayotte (Comoros Island), La Réunion and Madagascar, with the description of a new genus and two new species. Zootaxa, 2612: 57-68.

At http://decapoda.nhm.org/pdfs/31573/31573.pdf

Malay M. C. and G. Paulay

2009. Peripatric speciation drives diversification and distributional pattern of reef hermit crabs (Decapoda: Diogenidae: Calcinus). Evolution, 64(3): 634-662.

Manning R. B.

1968. Stomatopod Crustacea from Madagascar. Proceedings of the United States National Museum, 124 (3641): 1-61.

At http://biodiversitylibrary.org/page/7510559

McLaughlin P. A.

2004. A review of the hermit crab genus Nematopagurus A. Milne-Edwards and Bouvier, 1892, and the descriptions of five new species (Crustacea: Decapoda: Paguridae), In Marshall B. and B. Richer de Forges (eds), Tropical Deep-Sea Benthos, volume 23. Mémoires du Muséum national d'Histoire naturelle, 191 : 151-229. 
McLaughlin P. A. and P. J. Hogarth

1998. Hermit crabs (Decapoda: Anomura: Paguridae) from the Seychelles. Zoologische Verhandelingen, 318: 1-48.

At http://www.repository.naturalis.nl/document/149015

McLaughlin P. A. and R. Lemaitre

2009. A new classification for the Pylochelidae (Decapoda: Anomura: Paguroidea). The Raffles Bulletin of Zoology, Supplement, 20: 159-231.

At http://rmbr.nus.edu.sg/rbz/supplement20.html

McLaughlin P. A., Rahayu D. L., Komai T. and T.-Y. Chan.

2007. A catalog of the hermit crabs (Paguroidea) of Taiwan. National Taiwan Ocean University, Keelung: i-viii, 365 pp.

McLaughlin P. A., Boyko C. B., Crandall K. A., Komai T., Lemaitre R., Osawa M. and D. L. Rahayu

2010a. Annotated checklist of anomuran decapod crustaceans of the world (exclusive of the Kiwaoidea and families Chirostylidae and Galatheidae of the Galatheoidea) - Preamble and scope. The Raffles Bulletin of Zoology, supplement 23: 1-4.

At http://rmbr.nus.edu.sg/rbz/supplement23.html

McLaughlin P. A., Komai T., Lemaitre R. and D. L. Rahayu

2010b. Annotated checklist of anomuran decapod crustaceans of the world (exclusive of the Kiwaoidea, and families Chirostylidae and Galatheidae of the Galatheoidea). In: Low M. E. Y. and S. H. Tan (eds.), Part 1, Lithodoidea, Lomisoidea and Paguroidea. Raffles Bulletin of Zoology, supplement 23: 5-107.

At http://rmbr.nus.edu.sg/rbz/supplement23.html

Miers E. J.

1884. Crustacea. Report on the Zoological collection made in the Indo-Pacific Ocean during the voyage of H.M.S. Alert, 1881-1882. British Museum, London. Part II, The collections from the Western Indian Ocean: 513-575, pl. 46-52.

At http://www.biodiversitylibrary.org/item/63054

Moradmand M. and A. Sari

2007. Littoral hermit crabs (Decapoda: Anomura: Paguroidea) from the Gulf of Oman, Iran. Iranian Journal of Animal Biosystematics, 3(1): 25-36.

At http://www.sid.ir/en/VEWSSID/J_pdf/116420070103.pdf

Osawa M.

2001. Heteropolyonyx biforma, new genus and species from Japan, and redescription of Polyonyx utinomii (Decapoda: Porcellanidae). Journal of Crustacean Biology, 21(2): 506-520.

2007a. Porcellanidae (Crustacea: Decapoda: Anomura) from New Caledonia and the Loyalty Islands. Zootaxa, 1548: 1-49.

2007b. A new species of Polyonyx Stimpson, 1858 (Crustacea: Decapoda: Anomura: Porcellanidae) from the Philippines and Loyalty Islands. Zootaxa, 1450 : 21-29. 
Osawa M. and T.-Y. Chan

2010. Porcellanidae (Porcelain crabs), Part III. pp. 67-197. In: Chan T.-Y. (ed.) Crustacean Fauna of Taiwan: Crab-Like Anomurans (Hippoidea, Lithodoidea, and Porcellanidae). National Taiwan Ocean University, Keelung, 198 pp.

Osawa M. and P. A. McLaughlin.

2010. Annotated checklist of anomuran decapod crustaceans of the world (exclusive of the Kiwaoidea and families Chirostylidae and Galatheidae of the Galatheoidea) Part II Porcellanidae. The Raffles Bulletin of Zoology, supplement 23: 109-129.

At http://rmbr.nus.edu.sg/rbz/supplement23.html

Osawa M. and T. Komai

2007. A new hermit crab species of the Pagurixus anceps group (Crustacea: Decapoda: Anomura: Paguridae) from southern Japan, and supplemental notes on $P$. patiae Komai, 2006. Zootaxa, 1627: 41-51.

Osawa M., Boyko C. B. and T.-Y. Chan

2010. Hippoidea (Mole crabs). Part I. In: Chan T.-Y. (ed.) Crustacean Fauna of Taiwan: CrabLike Anomurans (Hippoidea, Lithodoidea, and Porcellanidae). National Taiwan Ocean University, Keelung, 198 pp.

Pollen F. P. L.

1868. Relation de Voyage. In: Pollen F. P. L. and D. C. Van Dam, Recherches sur la faune de Madagascar et de ses dépendances, d'après les découvertes de François P. L. Pollen et D. C. Van Dam, ouvrage dédié à S. M. Guillaume III, Roi des Pays-Bas, ${ }^{\text {ère }}$ Partie. Steenhoff J. K. (ed.), Leyde, 240 pp, 49 plates.

At http://www.biodiversitylibrary.org/item/100051

Poupin J.

2009. Crustacés de la Réunion, Décapodes et Stomatopodes. IRD Editions, Marseille: 140 pp. At http://horizon.documentation.ird.fr/exl-doc/pleins textes/ed-09-10/010050352.pdf

2010. Biodiversité de l'Indo-Pacifique tropical français : 2514 espèces de crustacés décapodes et stomatopodes. Rapport scientifique de l'Institut de Recherche de l'Ecole Navale, Octobre 2010, 76 pp.

At WoRMS http://www.marinespecies.org/aphia.php?p=sourcedetails\&id=147708

Poupin J. and M. Juncker

2008. Crustacés des îles Wallis \& Futuna: Inventaire illustré, espèces commercialisables et capture des formes larvaires. Rapport Technique du CRISP, janvier 2008: 1-43, pl. 1-7. At http://decapoda.nhm.org/pdfs/30457/30457.pdf

2010. Guide des crustacés décapodes du Pacifique Sud / A guide to South Pacific's decapods crustaceans. Guide de terrain - Field guide. CRISP, CPS, Nouméa (French/English), $317 \mathrm{pp}$.

At http://decapoda.nhm.org/pdfs/31614/31614.pdf

Poupin J. and P. A. McLaughlin

1998. Additional Calcinus (Decapoda, Anomura, Diogenidae) from French Polynesia with three new species and a key to Indo-West Pacific species. Crustacean Research, Tokyo, 27: 9-27.

At http://ci.nii.ac.jp/lognavi?name=nels\&lang=en\&type=pdf\&id=ART0002970323 
Poupin J. and M. C. Malay

2009. Identification of a Ciliopagurus strigatus (Herbst, 1804) species-complex, with description of a new species from French Polynesia (Crustacea, Decapoda, Anomura, Diogenidae). Zoosystema, 31(2): 209-232.

At http://www.mnhn.fr/museum/front/medias/publication/19399_z09n2a1.pdf

Rahayu D. L.

2007. The hermit crabs Paguristes Dana, 1851 s.l. (Crustacea, Decapoda, Anomura, Diogenidae) from the western Indian Ocean. Zoosystema, 29(3): 515-534.

At http://www.mnhn.fr/museum/front/medias/publication/11375_z07n3a6.pdf

Rahayu D. L. and J. Forest

1992. Le genre Clibanarius (Crustacea, Decapoda, Diogenidae) en Indonésie, avec la description de six espèces nouvelles. Bulletin du Muséum national d'Histoire naturelle, 14(3-4): 745-779.

1995. Le genre Diogenes (Decapoda, Anomura, Diogenidae) en Indonésie, avec la description de six espèces nouvelles. Bulletin du Muséum national d'Histoire naturelle, 1994 (1995), 16(2-4): 383-415.

1999. Sur le statut de Calcinus gaimardii (H. Milne Edwards, 1848) (Decapoda, Anomura, Diogenidae) et description de deux espèces nouvelles apparentées. Zoosystema, 21(3): 461-472.

Rahayu L. D. and P. A. McLaughlin

2010. Areopaguristes, a generic replacement name for Stratiotes Thomson, 1899 (Crustacea: Decapoda: Paguroidea: Diogenidae). Zootaxa, 2509: 67-68.

Reay P. J. and J. Haig

1990. Coastal hermit crabs (Decapoda: Anomura) from Kenya, with a review and key to east African species. Bulletin of Marine Science, 46(3): 578-589.

At http://www.ingentaconnect.com/content/umrsmas/bullmar/1990/00000046/00000003/art00002

Schnabel K. E., Ahyong S. T. and E. W. Maas

2011. Galatheoidea are not monophyletic - Molecular and morphological phylogeny of the squat lobsters (Decapoda: Anomura) with recognition of a new superfamily. Molecular Phylogenetics and Evolution, 58: 157-168.

At http://decapoda.nhm.org/pdfs/31737/31737.pdf

Serène R.

1977. Crustacés Hippidés et Brachyoures des îles Seychelles (1ère partie). Revue de Zoologie Africaine, 91(1): 45-68.

Thomassin B.

1969. Identification, variabilité et écologie des Hippidae (Crustacea, Anomura) de la région de Tuléar, S. W. de Madagascar. Recueil des Travaux de la Station Marine d'Endoume, fascicule hors série, supplément 9: 135-177.

Thomassin B., Andréfouët S., Bouchard J.-M., Charpy L., Dinhut V., Quod J.-P., Vicente N. and J. Wickel

2009. Geyser et Zélée: les sommets d'un même volcan sous-marin. Univers Maoré, 12: 22-29. 
Vuillemin S.

1970. Observations éthologiques sur Coenobita brevimanus Dana, 1852 (Crustacé, Décapode, Anomoure). Annales de l'Université de Madagascar, série Sciences de la Nature et Mathématiques, 7: 235-244.

At http://madarevues.recherches.gov.mg/revues/pdfxfiles/Anal-sciences7(24).pdf

Yu H. P. and K. Y. Foo

1991. Hermit crabs of Taiwan. S.C. Publishing Inc., Taipei, Taiwan, 78 pp.

\section{WEBSITES}

[1] Poupin J., Bouchard J.-M., Cleva R., Dumas J. and V. Dinhut. Base de données Internet pour l'inventaire des crustacés de la région de Mayotte.

http://crustaceamayotte.free.fr/

[2] IFREMER - Base de données Ecologie Benthique en Environnement Profond.

http://www.ifremer.fr/biocean/acces_fr/rapports/Appel_2cruisefr.htql?numcruise=43\&cruisename=BENTHEDI

[3] MNHN Paris, La planète revisitée 'Expédition MIRIKY'

http://www.laplaneterevisitee.org/fr/108/expedition_miriky_collecte_dans_le_canal_du_mozambique

[4] Appeltans W, Bouchet P, Boxshall G. A., Fauchald K, Gordon D. P., Hoeksema B. W., Poore G. C. B., van Soest R. W. M., Stöhr S., Walter T. C., Costello M. J. (eds). WoRMS, World Register of Marine Species.

http://www.marinespecies.org/

[5] DORIS. Données d'Observations pour la Reconnaissance et l'Identification de la faune et de la flore Subaquatiques.

http://doris.ffessm.fr/

[6] Poupin J. and J. Massoukou. Biodiversité de l'île de la Réunion : crustacés décapodes et stomatopodes.

$\underline{\text { http://biodivreunion.free.fr and http://biodiv-reunion.ecole-navale.fr }}$

[7] Yvon Gildas. Mayotte Photos Plongées. Albums.

http://www.mayotte-photos-plongee.com/albums-2.html

[8] Database of Crustacea (Decapoda and Stomatopoda), from Central Pacific Islands (French Polynesia, Pitcairn, Easter Island, Clipperton).

http://decapoda.ecole-navale.fr/index.php and http://decapoda.free.fr 


\section{APPENDICES}

\section{STATIONS}

Station list for Mayotte KUW fieldwork is available in Bouchard et al. (2011, fig. 3 and appendix 1). Stations not included in that report from Glorioso Islands sampled by M. Malay and colleagues in May 2009 for the BIOTAS program in WIO are listed below. For each station the following sequence is used: station number; date; place; latitude (S); longitude (E); depth (m); collector(s).

GLOR-1; 03/05/2009; patch reef, near anchorage; 15 min dive; 11³3'54.4"S, 47²17'28.6"E; 24 m; M. Malay, M. Guillaume, J.B. Galves, V. Denis.

GLOR-2; 04/05/2009; reef platform and shallow canyons with dead Acropora digitifera head;

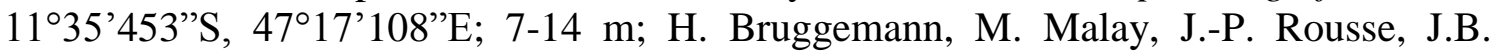
Galves.

GLOR-3; 04/05/2009; reef platform, sandy, beneath a slope; 12-20 m; 11³5.453'S, 47¹7.108'E; V. Denis, M. Guillaume.

GLOR-4; 04/05/2009; patch reef, near anchorage; 3-6 m; 11³3'54.4”S, 47¹7'28.6”E; V. Denis, M. Guillaume, H. Bruggemann, J.-P. Rousse, J.B. Galves.

GLOR-5; 05/05/2009; reef slope East side; 17-17 m; M. Malay, M. Guillaume, V. Denis, J.-P. Rousse, J.B. Galves.

GLOR-6; 05/05/2009; patch reef, near anchorage, Chabanet's camera site; 2-3 m; J.B. Galves, J.P. Rousse.

GLOR-7; 05/05/2009; reef slope West side; 5-20 m; M. Malay, H. Bruggemann, V. Denis, M. Guillaume.

GLOR-8; 05/05/2009; beach landing site; 0 m; J.B. Galves.

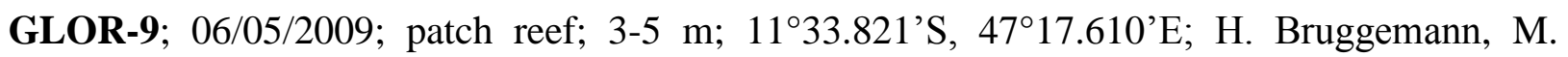
Guillaume, V. Denis, J.B. Galves.

GLOR-10; 06/05/2009; near military base, reef slope; 15-20 m; M. Malay, J.-P. Rousse, J.B. Galves.

GLOR-11; 06/05/2009; reef slope in front of military camp, ARMS; 14-16 m; 11³5.453'S, 47¹7.093'E; M. Guillaume, H. Bruggemann, J.-P. Rousse, J.B. Galves.

GLOR-12; 07/05/2009; exposed reef flat, abrasion platform; 1-3 m; M. Guillaume, H. Bruggemann, M. Malay, V. Denis, A. Chauvin, D. Ringler, K. Coustaut.

GLOR-13; 07/05/2009; in front of Military camp, on 'Îlot aux crabes'; intertidal; J.B. Galves.

GLOR-14; 08/05/2009; fore reef platform; 13-14.5 m; M. Guillaume, H. Bruggemann, M. Malay. 
GLOR-15; 08/05/2009; reef front S side; 7-14.5 m; H. Bruggemann, M. Guillaume, J.-P. Rousse, J.B. Galves.

GLOR-16; 08/05/2009; reef flat all along coast of Grande Glorieuse; 0-3 m; V. Denis.

\section{VERTICAL RANGES}

The vertical ranges of the species indicated in the following tables are defined as follow: supra-tidal; intertidal; shallow waters $(0-60 \mathrm{~m})$; and deep sea (60 to $+1000 \mathrm{~m})$.

Table 2. Anomura (Galatheoidea and Hippoidea) from Mayotte region, with indication of vertical range ( $\mathbf{x}$ observed; $\mathbf{x}$, potential). Species in bold are first records for Mayotte region. Species highlighted in grey are reported in WIO only; other species are distributed in the IWP.

\begin{tabular}{|c|c|c|c|c|c|c|}
\hline Superfamily & Family & Species & Supra-tidal & Intertidal & $\begin{array}{l}\text { Shallow } \\
\text { waters }\end{array}$ & Deep \\
\hline Chirostyloidea & Chirostylidae & Eumunida sp. & & & & $\mathbf{x}$ \\
\hline \multirow{22}{*}{$\begin{array}{l}\mathbb{J} \\
\frac{\mathbb{D}}{0} \\
\frac{0}{0} \\
\frac{d}{ \pm} \\
\frac{\pi}{\pi} \\
\frac{\pi}{0}\end{array}$} & \multirow{7}{*}{ Galatheidae } & Galathea aegyptiaca & & & $\mathbf{x}$ & \\
\hline & & Galathea amamiensis & & $x$ & $\mathbf{x}$ & \\
\hline & & Galathea denticulata & & & $\mathbf{x}$ & \\
\hline & & Galathea mauritiana & & $x$ & $\mathbf{x}$ & \\
\hline & & Galathea spinosorostris & & $x$ & $\mathbf{x}$ & \\
\hline & & Galathea tanegashimae & & $x$ & $\mathbf{x}$ & \\
\hline & & Macrothea bouchardi & & & $\mathbf{x}$ & \\
\hline & \multirow{2}{*}{ Munididae } & Munida sp. & & & & $\mathbf{x}$ \\
\hline & & Sadayoshia edwardsii & & $x$ & $\mathbf{x}$ & \\
\hline & \multirow{13}{*}{ Porcellanidae } & Aliaporcellana pygmaea & & $x$ & $\mathbf{x}$ & \\
\hline & & Neopetrolisthes maculatus & & & $\mathbf{x}$ & \\
\hline & & Pachycheles sculptus & & & $\mathbf{x}$ & \\
\hline & & Petrolisthes decacanthus & & $\mathbf{x}$ & & \\
\hline & & Petrolisthes lamarckii & & $\mathbf{x}$ & & \\
\hline & & Petrolisthes ornatus & & $\mathbf{x}$ & & \\
\hline & & Petrolisthes rufescens & & $\mathbf{x}$ & & \\
\hline & & Petrolisthes tomentosus & & $\mathbf{x}$ & & \\
\hline & & Pisidia delagoae & & $\mathbf{x}$ & & \\
\hline & & Polyonyx biunguiculatus & & & $\mathbf{x}$ & \\
\hline & & Polyonyx boucheti aff. & & & $\mathbf{x}$ & \\
\hline & & Polyonyx pedalis & & & $\mathbf{x}$ & \\
\hline & & Polyonyx triunguiculatus & & & $\mathbf{x}$ & \\
\hline Hippoidea & Hippidae & Hippa adactyla & & $\mathbf{x}$ & & \\
\hline
\end{tabular}


Table 2. Same. Anomura (Coenobitidae and Diogenidae).

\begin{tabular}{|c|c|c|c|c|c|c|}
\hline Superfamily & Family & Species & Supra-tidal & Intertidal & $\begin{array}{l}\text { Shallow } \\
\text { waters }\end{array}$ & Deep \\
\hline \multirow{34}{*}{ 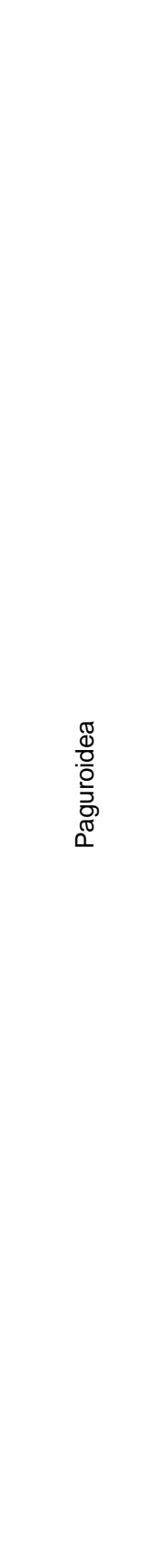 } & \multirow{5}{*}{ Coenobitidae } & Birgus latro & $\mathbf{x}$ & & & \\
\hline & & Coenobita brevimanus & $\mathbf{x}$ & & & \\
\hline & & Coenobita cavipes & $\mathbf{x}$ & & & \\
\hline & & Coenobita perlatus & $\mathbf{x}$ & $\mathbf{x}$ & & \\
\hline & & Coenobita rugosus & $\mathbf{x}$ & $\mathbf{x}$ & & \\
\hline & \multirow{29}{*}{ Diogenidae } & Aniculus maximus & & & $\mathbf{x}$ & \\
\hline & & Aniculus retipes & & & $\mathbf{x}$ & \\
\hline & & Aniculus ursus & & & $\mathbf{x}$ & \\
\hline & & Areopaguristes abbreviatus & & & $\mathbf{x}$ & \\
\hline & & Areopaguristes micheleae & & & & $\mathbf{x}$ \\
\hline & & Calcinus laevimanus & & $\mathbf{x}$ & $\mathbf{x}$ & \\
\hline & & Calcinus latens & & $\mathbf{x}$ & $\mathbf{x}$ & \\
\hline & & Calcinus morgani & & $x$ & $\mathbf{x}$ & \\
\hline & & Calcinus pulcher aff. & & & $\mathbf{x}$ & \\
\hline & & Calcinus rosaceus & & $\mathbf{x}$ & $\mathbf{x}$ & \\
\hline & & Calcinus vachoni aff. & & & $\mathbf{x}$ & \\
\hline & & Ciliopagurus tricolor & & $\mathbf{x}$ & $\mathbf{x}$ & \\
\hline & & Clibanarius englaucus & & $\mathbf{x}$ & & \\
\hline & & Clibanarius eurysternus & & $\mathbf{x}$ & $\mathbf{x}$ & \\
\hline & & Clibanarius humilis & & $\mathbf{x}$ & & \\
\hline & & Clibanarius laevimanus & & $\mathbf{x}$ & & \\
\hline & & Clibanarius longitarsus & $\mathbf{x}$ & $\mathbf{x}$ & & \\
\hline & & Clibanarius rhabdodactylus & & $\mathbf{x}$ & & \\
\hline & & Clibanarius virescens & & $\mathbf{x}$ & $\mathbf{x}$ & \\
\hline & & Dardanus deformis & & & $\mathbf{x}$ & \\
\hline & & Dardanus gemmatus & & $\mathbf{x}$ & $\mathbf{x}$ & \\
\hline & & Dardanus guttatus & & & $\mathbf{x}$ & \\
\hline & & Dardanus lagopodes & & & $\mathbf{x}$ & \\
\hline & & Dardanus megistos & & & $\mathbf{x}$ & \\
\hline & & Dardanus pedunculatus & & & $\mathbf{x}$ & \\
\hline & & Dardanus scutellatus & & & $\mathbf{x}$ & \\
\hline & & Diogenes pallescens & & & $\mathbf{x}$ & \\
\hline & & Paguristes palythophilus & & & & $\mathbf{x}$ \\
\hline & & Pseudopaguristes laurentae & & & & $\mathbf{x}$ \\
\hline
\end{tabular}


Table 2. Same. Anomura (Paguridae, Parapaguridae, Pylochelidae).

\begin{tabular}{|c|c|c|c|c|c|c|}
\hline Superfamily & Family & Species & Supra-tidal & Intertidal & $\begin{array}{l}\text { Shallow } \\
\text { waters }\end{array}$ & Deep \\
\hline \multirow{17}{*}{ 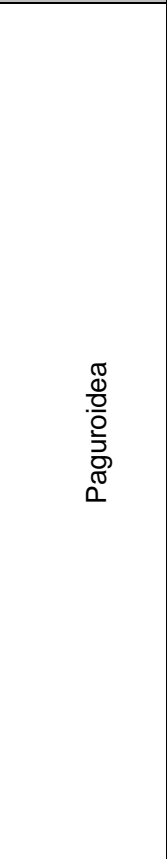 } & \multirow{11}{*}{ Paguridae } & Anapagrides reesei & & $\mathbf{x}$ & & \\
\hline & & Catapagurus sp. & & & $\mathbf{x}$ & \\
\hline & & Pagurixus carinimanus & & & $\mathbf{x}$ & \\
\hline & & Pagurixus nomurai & & & $\mathbf{x}$ & \\
\hline & & Pagurixus patiae & & & $\mathbf{x}$ & \\
\hline & & Pagurixus purpureus & & & $\mathbf{x}$ & \\
\hline & & Pagurixus ruber & & & $\mathbf{x}$ & \\
\hline & & Pagurixus rubrovittatus & & & $\mathbf{x}$ & \\
\hline & & Pagurus hirtimanus & & & $\mathbf{x}$ & \\
\hline & & Pylopaguropsis keijii & & & $\mathbf{x}$ & \\
\hline & & Trichopagurus trichophthalmus & & & $\mathbf{x}$ & \\
\hline & \multirow{3}{*}{ Parapaguridae } & Paragiopagurus boletifer & & & & $\mathbf{x}$ \\
\hline & & Strobopagurus sibogae & & & & $\mathbf{x}$ \\
\hline & & Sympagurus dofleini & & & & $\mathbf{x}$ \\
\hline & \multirow{3}{*}{ Pylochelidae } & Cheiroplatea stenurus & & & & $\mathbf{x}$ \\
\hline & & Pomatocheles stridulans & & & & $\mathbf{x}$ \\
\hline & & Trizocheles hoensonae & & & & $\mathbf{x}$ \\
\hline
\end{tabular}




\section{INDEX}

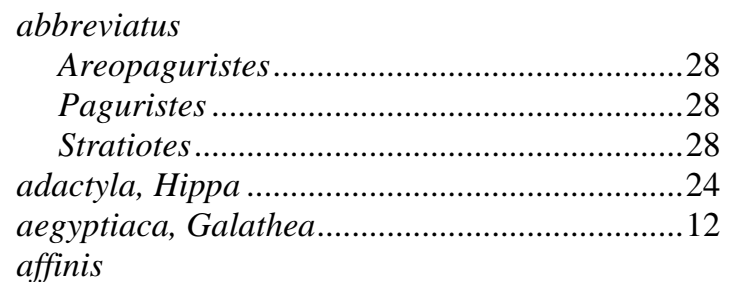

Galathea ......................................................... 14

Sympagurus ..............................................55

Albunea

elioti..........................................................54

holthuisi ..................................................5

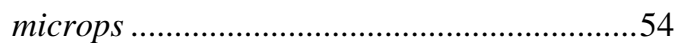

speciosa ........................................................54

ALBUNEIDAE .................................................54

Aliaporcellana

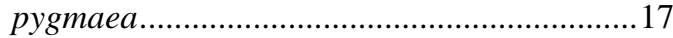

suluensis ......................................................... 17

Allogalathea elegans ............................................53

alobatus, Neopetrolisthes ..................................53

amamiensis, Galathea ........................................ 12

Anapagrides reesei ..........................................4 43

anceps, Pagurixus .............................................5 54

andersoni, Sympagurus .......................................55

Aniculus

aniculus.....................................................26

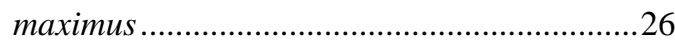

ursus .......................................................26

aniculus, Aniculus ............................................26

antennarius, Paguristes......................................54

Areopaguristes

abbreviatus ..................................................2 28

micheleae ..................................................... 28

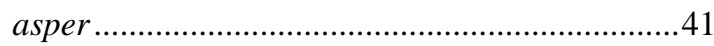

Dardanus ......................................................41

Trichopagurus ...............................................43

avarus, Diogenes ................................................54

balssi, Trizocheles .............................................50

barbeti, Munida .................................................5

Birgus latro ......................................................25

biunguiculatus, Polyonyx ................................22

boletifer

Paragiopagurus ............................................48

Sympagurus .............................................4 48

Boninpagurus aff. acanthocheles. ......................43

bouchardi, Macrothea .........................................16

boucheti aff., Polyonyx ....................................22

brachyops, Dardanus ........................................54 brevimanus, Coenobita ......................................25

brevipes, Sympagurus ......................................55

burkenroadi, Sympagurus.................................55

Calcinus

gaimardii ....................................................... 30

guamensis ....................................................54

haigae ................................................... 31,32

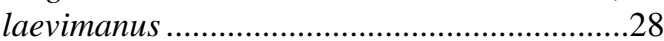

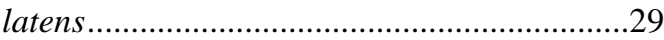

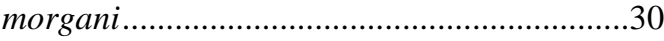

pulcher aff..................................................... 31

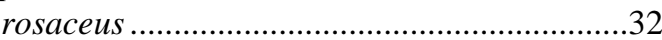

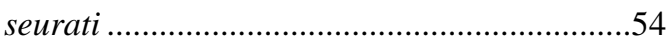

tropidomanus ...............................................54

vachoni aff. ..................................................33

carinimanus, Pagurixus ....................................44

Catapagurus

ensifer ....................................................44, 54

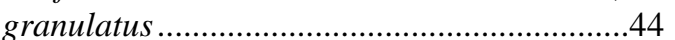

sp. 44

cavipes, Coenobita.............................................25

caeruleus, Cestopagurus. .................................43

Cestopagurus caeruleus. ....................................43

Cheiroplatea stenurus.......................................50

CHIROSTYLIDAE .................................11, 53

Ciliopagurus

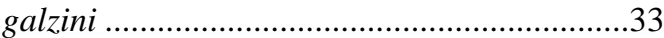

shebae ........................................................54

tricolor ............................................................33

vakovako .........................................................

Clibanarius

englaucus ....................................................33

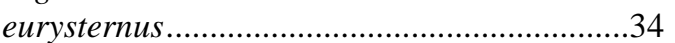

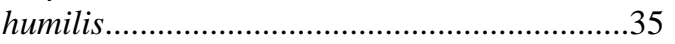

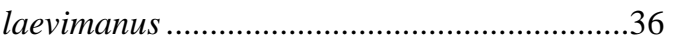

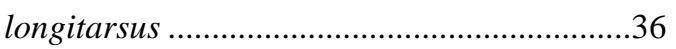

merguiensis ......................................... 34, 54

ransoni ........................................................... 35

rhabdodactylus ...............................................36

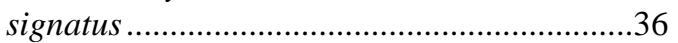

striolatus .............................................36, 54

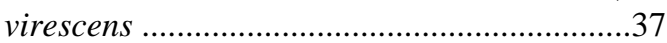

coccineus, Petrolisthes .....................................53

Coenobita

brevimanus.....................................................2 25

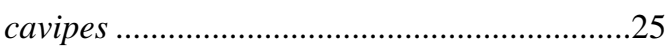

perlatus ......................................................25

rugosus........................................................26 


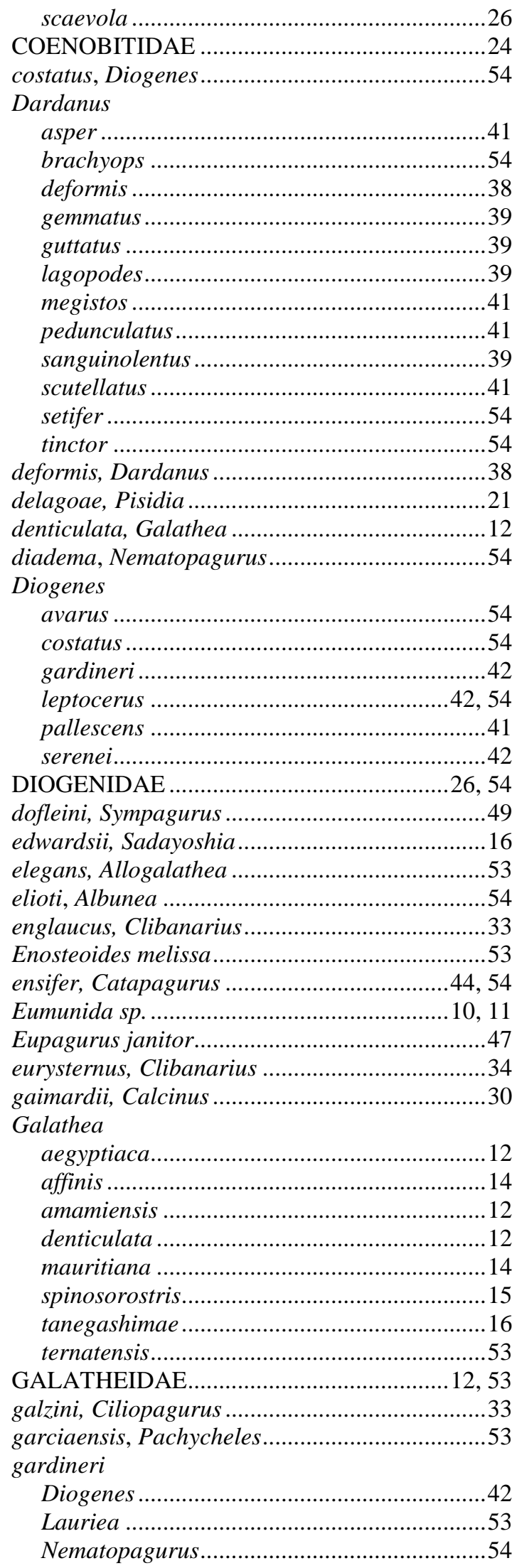

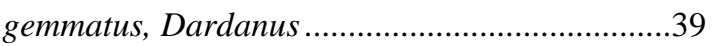

granulatus, Catapagurus ....................................44

guamensis, Calcinus .......................................54

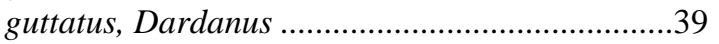

haigae, Calcinus ........................................31, 32

Hippa

adactyla...................................................24

marmorata ..................................................54

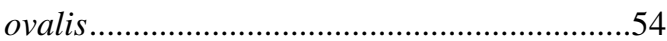

HIPPIDAE ...........................................24, 54

hirtimanus, Pagurus ........................................47

hoensonae, Trizocheles......................................50

holthuisi, Albunea ...............................................54

humilis, Clibanarius ...........................................35

integrirostris, Phylladiorhynchus .......................53

janitor

Eupagurus..............................................4

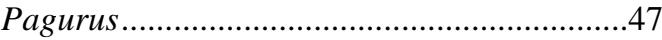

jousseaumei, Paguristes .....................................28

keijii, Pylopaguropsis .......................................47

laevimanus

Calcinus ......................................................28

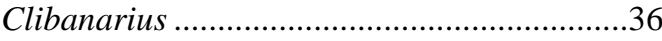

laevirostris, Leiogalathea ...................................53

lagopodes, Dardanus.........................................39

lamarckii, Petrolisthes ........................................20

latens, Calcinus ................................................29

latro, Birgus...................................................25

laurentae, Pseudopaguristes..............................43

Lauriea gardineri ..............................................53

lauriei, Paguristes .............................................54

Leiogalathea laevirostris ...................................53

lemaitrei, Pylopaguropsis.................................47

leptocerus, Diogenes ...................................42, 54

Lissoporcellana quadrilobata .............................53

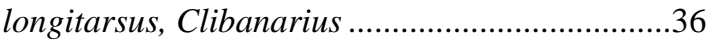

Macrothea bouchardi .........................................16

maculatus, Neopetrolisthes .................................17

maorus, Pagurixus.............................................46

marmorata, Hippa .............................................54

mauritiana, Galathea.........................................14

maximus, Aniculus ..........................................26

megistos, Dardanus ...........................................41

melissa, Enosteoides ..........................................53

merguiensis, Clibanarius...............................34, 54

micheleae

Areopaguristes ...............................................28

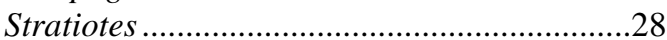

Micropagurus aff. polynesiensis .........................43

microps, Albunea ...............................................54

militaris, Petrolisthes.........................................53

moluccensis, Petrolisthes....................................53

morgani, Calcinus ................................................30

Munida

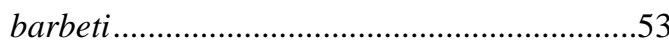




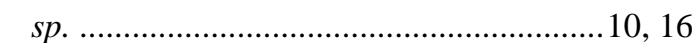

MUNIDIDAE ..........................................16, 53

MUNIDOPSIDAE...........................................5

Munidopsis serricornis ....................................53

natalensis, Pachycheles.............................18, 53

Nematopagurus

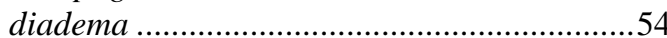

gardineri .....................................................54

spinulosensoris ............................................54

Neopetrolisthes

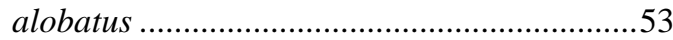

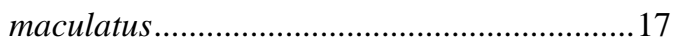

ohshimai .................................................. 17

nigricapillis, Uroptychus ...................................53

nomurai, Pagurixus ...........................................45

obesulus, Polyonyx .............................................22

ohshimai, Neopetrolisthes ................................. 17

ornatus, Petrolisthes........................................20

ovalis, Hippa ......................................................54

Pachycheles

garciaen sis...................................................53

natalensis .......................................... 18, 53

pisoides ..................................................53

sculptus ....................................................... 18

PAGURIDAE ...........................................43, 54

Paguristes

abbreviatus ...................................................28

antennarius ..................................................5

jousseaumei ...............................................28

lauriei ............................................................54

palythophilus ................................................43

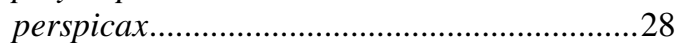

puniceus .....................................................5 54

Pagurixus

anceps .....................................................54

carinimanus ................................................ 44

maorus, aff............................................... 46

nomurai........................................................45

patiae ............................................................45

purpureus....................................................45

ruber .......................................................... 45

rubrovittatus, aff.........................................46

Pagurus

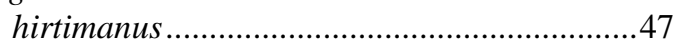

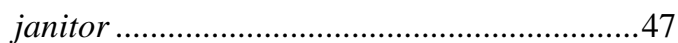

pallescens, Diogenes ..........................................41

palythophilus, Paguristes ...................................4 43

Paragiopagurus boletifer .................................48

Paramunida tricarinata......................................53

PARAPAGURIDAE .................................48, 55

patiae, Pagurixus................................................ 45

pedalis, Polyonyx...............................................22

pedunculatus, Dardanus....................................41

penicillatus, Petrolisthes ...................................21

perlatus, Coenobita ..........................................25 perspicax, Paguristes......................................28

Petrolisthes

coccineus.....................................................5

lamarckii ...................................................20

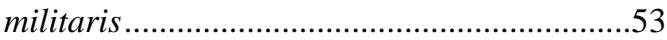

moluccensis ................................................53

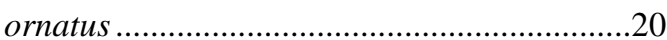

penicillatus..................................................21

pubescens .....................................................21

rufescens ....................................................21

tomentosus ...................................................21

Phylladiorhynchus integrirostris .......................53

Pisidia pubescens .............................................21

pisoides, Pachycheles ........................................53

polynesiensis aff., Micropagurus ........................43

Polyonyx

biunguiculatus...........................................22

boucheti aff. ................................................22

obesulus .........................................................22

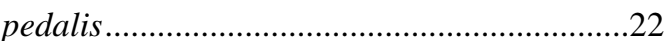

spina ...........................................................22

triunguiculatus .........................................23

utinomii ...............................................22

Pomatocheles stridulans ...................................50

PORCELLANIDAE .................................17, 53

Pseudopaguristes laurentae .................................43

pubescens, Petrolisthes.......................................21

pulcher aff., Calcinus .........................................31

puniceus, Paguristes ........................................54

purpureus, Pagurixus .........................................45

pygmaea, Aliaporcellana ....................................17

PYLOCHELIDAE ..............................................49

Pylopaguropsis

keijii ............................................................4 47

lemaitrei ........................................................47

quadrilobata, Lissoporcellana ............................53

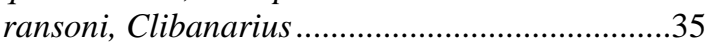

reesei, Anapagrides ............................................43

rhabdodactylus, Clibanarius ...............................36

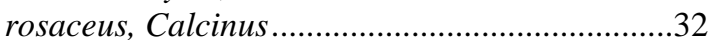

ruber, Pagurixus .................................................45

rubrovittatus., Pagurixus ...................................46

rufescens, Petrolisthes .......................................21

rugosus, Coenobita..............................................26

Sadayoshia edwardsii ........................................16

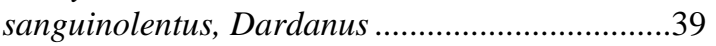

scaevola, Coenobita............................................26

sculptus, Pachycheles .......................................18

scutellatus, Dardanus ..........................................41

serenei, Diogenes...............................................42

serricornis, Munidopsis .......................................53

setifer, Dardanus ...............................................54

seurati, Calcinus ..................................................54

shebae, Ciliopagurus .......................................54

sibogae, Strobopagurus .......................................48 
signatus, Clibanarius............................................. 36

speciosa, Albunea .............................................54

spina, Polyonyx ..............................................22

spinosorostris, Galathea...................................15

spinulosensoris, Nematopagurus........................54

stenurus, Cheiroplatea .....................................50

Stratiotes

abbreviatus ..................................................28

micheleae .......................................................28

stridulans, Pomatocheles....................................50

striolatus, Clibanarius ..................................36, 54

Strobopagurus sibogae ......................................48

suluensis, Aliaporcellana .................................. 17

Sympagurus

affinis .........................................................55

andersoni ....................................................55

boletifer.......................................................48

brevipes.......................................................55

burkenroadi .................................................55

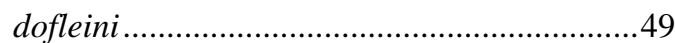

trispinosus...................................................55

tanegashimae, Galathea ...................................16 ternatensis, Galathea ........................................53

tinctor, Dardanus..............................................54

tomentosus, Petrolisthes ..................................21

tricarinata, Paramunida ..................................53

Trichopagurus

asper .......................................................43

trichophthalmus .........................................48

trichophthalmus, Trichopagurus .......................48

tricolor, Ciliopagurus ........................................33

trispinosus, Sympagurus ..................................55

triunguiculatus, Polyonyx ................................23

Trizocheles

balssi ..........................................................50

hoensonae ......................................................50

tropidomanus, Calcinus ......................................54

Uroptychus nigricapillis ..................................53

ursus, Aniculus ..............................................26

utinomii, Polyonyx ..........................................22

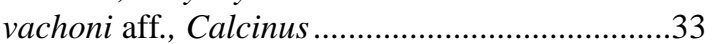

vakovako, Ciliopagurus .........................................33

virescens, Clibanarius .........................................37

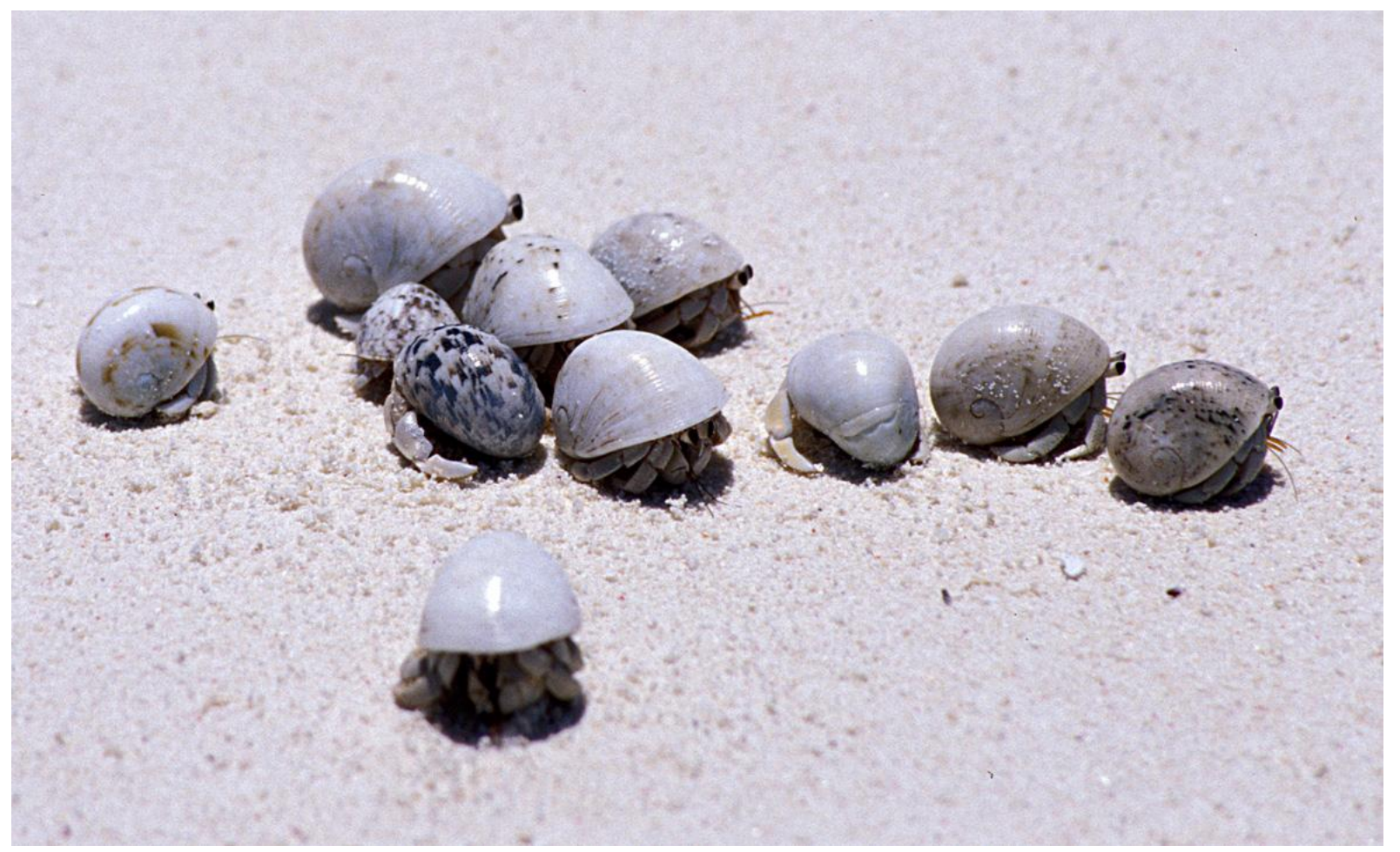

Figure 28. Colony of young Coenobita rugosus on Glorioso beach. Photo Mathieu Foulquié. 